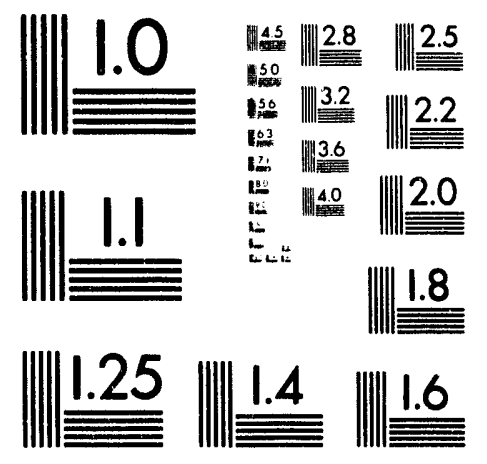



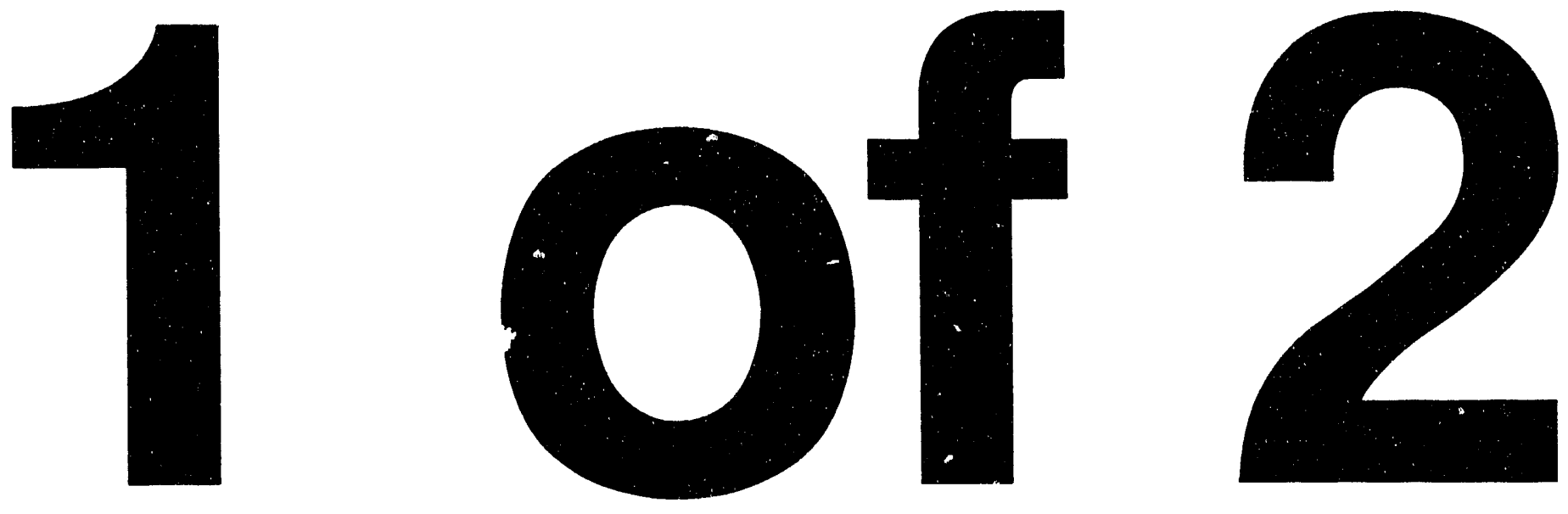


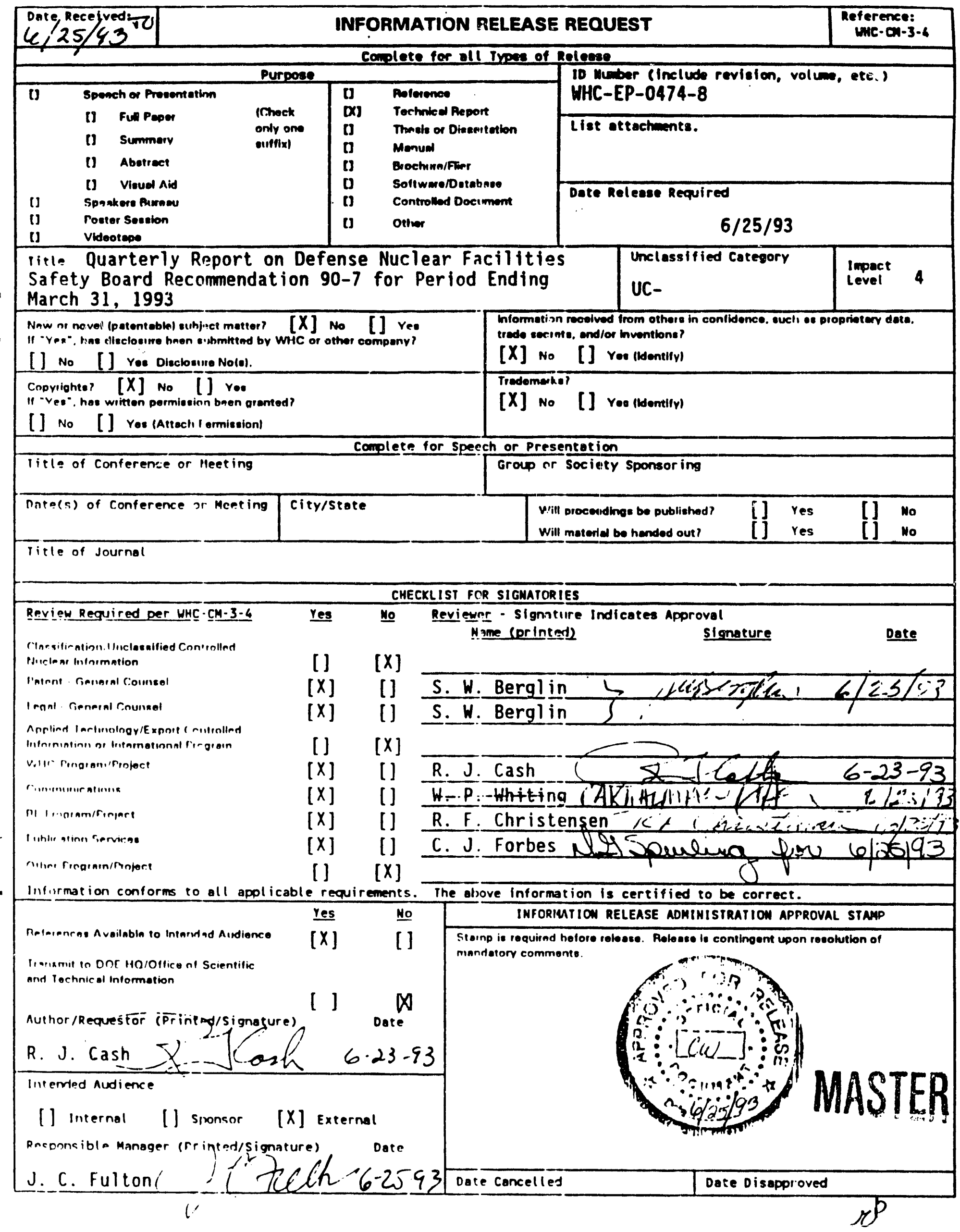




\title{
Quarterly Report on Defense Nuclear Facilities Safety Board Recommendation 90-7 for the Period Ending March 31, 1993
}

\author{
R. J. Cash \\ G. T. Dukelow \\ C. J. Forbes \\ J. E. Meacham
}

Date Published

June 1993

Prepared for the U. S. Department of Energy Office of Environmental Restoration and Waste Management

\footnotetext{
(2) Westinghouse P.O. Box 1970

Hanford Company Richland, Washington 99352

Hantord Operatoons and Engineenng Contractor for the

U.S. Department of Energy under Contract DE.AC06.87RL10930
} 


\title{
QUARTERLY REPORT ON DEFENSE NUCLEAR FACILITIES SAFETY BOARD RECOMMENDATION 90-7 FOR THE PERIOD ENDING MARCH 31, 1992
}

\author{
R. J. Cash \\ G. T. Dukelow \\ C. J. Forbes \\ J. E. Meacham
}

\begin{abstract}
This is the eighth quarterly report on the progress of activities addressing safety issues associated with Hanford Site high-level radioactive waste tanks that contain ferrocyanide compounds. In the presence of oxidizing materials, such as nitrates or nitrites, ferrocyanide can be made to explode in the laboratory by heating it to high temperatures [above $285^{\circ} \mathrm{C}$ $\left.\left(545^{\circ} \mathrm{F}\right)\right]$. In the mid 1950s, approximately 140 metric tons of ferrocyanide were added to 24 underground high-level radioactive waste tanks. An implementation plan (Cash 1991)* responding to the Defense Nuclear Facilities Safety Board Recommendation 90-7 (FR 1990)* was issued in March 1991 describing the activities that were planned and underway to address each of the six parts of Recommendation 90-7. A revision to the original plan was transmitted to the U.S. Department of Energy by Westinghouse Hanford Company in December 1992.
\end{abstract}

The revised implementation plan describes the progress made on Ferrocyanide Safety Program activities since the beginning of the program in September 1990, as well as those 


\section{WHC-EP-0474-8}

continuing tasks that address or supplement the six parts of Recommendation 90-7. The plan incorporates comments received from various reviewers after preparation of draft issues in June and September 1992. The revised plan provides an updated schedule, and includes the current status of understanding on the ferrocyanide safety issue. The document was approved for public availability and will be distributed after transmittal to the Defense Nuclear Facilities Safety Board by the U.S. Department of Energy.

Milestones completed this quarter include (1) preparation of safety and environmental documentation for DOE approval to install thermocouple trees in assumed leaker ferrocyanide tanks; (2) preliminary neutron probe moisture evaluations using limited moisture simulant drims; (3) an environmental specification document for a hot cell and waste tank deployable Raman system; (4) renewal of the Florida State University contract for evaluating the application of Raman spectroscopy to detection and quantification of cyanide species in tank waste; (5) a report discussing the probability of a hot spot within the ferrocyanide tanks;

(6) a report on the airflow patterns in ferrocyanide tank 241-C-109; (7) a document on ferrocyanide waste simulant characteristics; and (8) a predecisional Ferrocyanide Unreviewed Safery Question closure plan.

Installation of new thermocouple trees into tanks $241-B Y-111$ and -112 , two of the last six non-leaking ferrocyanide tanks, was completed. The thermocouple tree in tank 241-BY-111 
stopped two feet, nine inches from the bottom of the tank when it hit either a hard waste layer or a failed piece of equipment. An evaluation is being made to determine if the thermocouple tree will be adequate for monitoring.

A contract was established with the University of Washington's Center for Process Analytical Chemistry to complete an initial evaluation of the potential for measuring saltcake surface moisture with infrared spectroscopy. This technology has been applied commercially, and the Center for Process Analytical Chemistry has experience with infrared moisture sensing of cookie dough.

A report on ferrocyanide waste simulant characteristics was completed. Adiabatic calorimetry and reaction propagation rate tests on simulants demonstrated that propagating reactions cannot occur in waste containing more that $12 \mathrm{wt} \%$ free water. Also, a ferrocyanide concentration greater than $13 w t \%$ is required to sustain a propagating reaction in dry material.

The heat of reaction values for ferrocyanide waste in tank 241-C-112 are lower by at least a factor of ten than those predicted by ferrocyanide waste simulants. It has been postulated that low cyanide and heat of reaction values are the result of aging of the ferrocyanide waste. Core samples of tank 24I-C-109 demonstrated comparable or even lower heat of reaction values than samples from 241-C-112. The highest heat of reaction observed for the 241-C-112 material was $-8.6 \mathrm{cal} / \mathrm{g}$ of dry waste. Propagating reactions are precluded in 
material with less than -100 cal/g heat of reaction. A report characterizing the waste in tank 241-C-112 concluded that the waste cannot support a propagating reaction, even when dry.

Preliminary aerosol tests at Fauske and Associates, Inc., were conducted with the most reactive In Farm simulant. Results showed that the aerosol collected contained up to $28 \%$ of the initial cesium content originally present on a per unit mass basis. This is a significant amount, and further tests are planned to study the parameters that affect the release of cesium.

Pumping of tank 241-T-101 commenced on March 12, 1993, after authorization was granted by DOE. At the end of the quarter, tank 241-BX-111 was declared to be an "assumed releaker" and planning is currently under way to pump this tank. 241-BX-111 was already on the assumed leaker list, and had been partially pumped a number of years earlier.

*Cash, R. J., 1991, Implementation Plan for the Defense Nuclear Facilities Safety Board Recommendation 90-7, WHC-EP-0415, Westinghouse Hanford Company, Richland, Washington.

*FR, 1990, "Implementation Plan for Recommendation 90-3 at the Department of Energy's Hanford Site, WA," Federal Register, DNFSB Recommendation 90-7, Vol. 55, No. 202, pp. 42243-44. 


\section{CONTENTS}

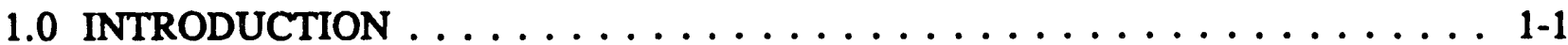

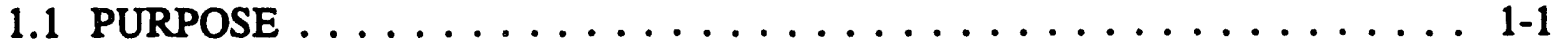

1.2 QUARTERLY HIGHLIGHTS $\ldots \ldots \ldots \ldots \ldots \ldots \ldots \ldots \ldots \ldots$

1.3 REPORT FORMAT $\ldots \ldots \ldots \ldots \ldots \ldots \ldots \ldots \ldots \ldots$

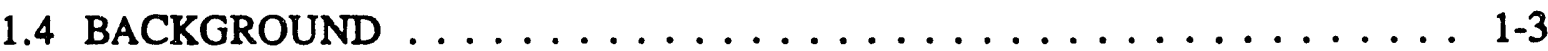

2.0 DEFENSE NUCLEAR FACILITIES SAFETY BOARD

IMPLEMENTATION PLAN TASK ACTIVITIES $\ldots \ldots \ldots \ldots \ldots . \ldots .2-1$

2.1 DEFENSE NUCLEAR FACILITIES SAFETY BOARD

RECOMMENDATION 90-7.1 (ENHANCED

TEMPERATURE MEASUREMENT) $\ldots \ldots \ldots \ldots \ldots \ldots \ldots \ldots$ 2-1

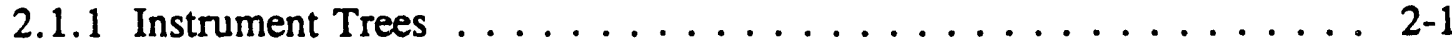

2.1.2 Upgrades to Existing Tank Temperature

Monitoring Instrumentation $\ldots \ldots \ldots \ldots \ldots \ldots \ldots$ 2-3

2.1.3 Alternate Monitoring Technologies . . . . . . . . . . . 2-4

2.1.4 Hot Spot Thermal Modeling . . . . . . . . . . . 2-15

2.2 DEFENSE NUCLEAR FACILITIES SAFETY BOARD

RECOMMENDATION 90-7.2 (CONTINUOUS

TEMPERATURE MONITORING) . . . . . . . . . . . . 2-17

2.2.1 Tank Monitoring and Control System . . . . . . . . 2-17

2.3 DEFENSE NUCLEAR FACILITIES SAFETY BOARD

RECOMMENDATION 90-7.3 (COVER GAS MONITORING) . . . . . 2 2-19

2.3.1 On-Line Gas Monitoring . . . . . . . . . . . . . . 2-19

2.3.2 Interim Flammable Gas Monitoring . . . . . . . . . . . 2-19

2.3.3 Vapor Space Gas Modeling . . . . . . . . . . . . 2-21

2.4 DEFENSE NUCLEAR FACILITIES SAFETY BOARD

RECOMMENDATION 90-7.4 (FERROCYANIDE

WASTE CHARACTERIZATION) . . . . . . . . . . . . 2-22

2.4.1 Ferrocyanide Tank Waste Sampling and

Characterization ................... 2-23

2.4.2 Simulated Ferrocyanide Waste Preparation and

Characterization . . . . . . . . . . . . . . 2-32

2.4.3 Position Paper on Safety of Ferrocyanide Tanks . . . . . . . . 2-34

2.4.4 Ferrocyanide Waste Tanks Hazards Assessment . . . . . . . . 2-36

2.4.5 Closure of the Ferrocyanide Unreviewed

Safety Question . . . . . . . . . . . . . . . 2-38

2.4.6 Concepts for Resolution of the
Ferrocyanide Safety Issue $\ldots \ldots \ldots \ldots \ldots \ldots \ldots . \ldots \ldots 2-41$

2.5 DEFENSE NUCLEAR FACILITIES SAFETY BOARD

RECOMMENDATION 90-7.5 (CHEMICAL

REACTION STUDIES) $\ldots \ldots \ldots \ldots \ldots \ldots \ldots \ldots \ldots . \ldots \ldots 2-43$ 


\section{CONTENTS (Continued)}

2.5.1 Chemical Reaction Studies at Pacific

Northwest Laboratory . . . . . . . . . . . . . . . . . . . . . 2-44 24

2.5 .2 Ferrocyanide Propagation Studies .............. 2-. 2-52

2.6 DEFENSE NUCLEAR FACILITIES SAFETY

BOARD RECOMMENDATION 90-7.6

(EMERGENCY RESPONSE PLANNING) . . . . . . . . . . . . . . 2-58

2.6.1 Action Plan for Response to Abnormal Conditions . . . . . . . . 2-59

2.6.2 Response to an Airborne Release

From a Ferrocyanide Tank . . . . . . . . . . . . . . . . . 2-61

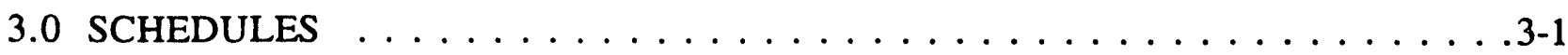

4.0 REFERENCES . . . . . . . . . . . . . . . . . . . . .

APPENDIXES

A LIST OF FERROCYANIDE TANKS AND

ANALYTES FOR TANK $241-\mathrm{C}-112 \ldots \ldots \ldots \ldots \ldots \ldots$ A-1

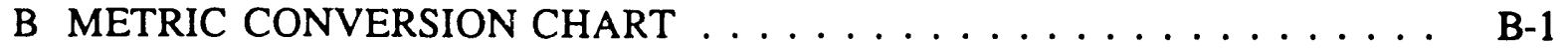




\section{LIST OF FIGURES}

2-1 Geometry of Limited Moisture Standards Containing an Aluminum Sheath.

2-2 Benchmarking Comparison of Measured Data With MCNP

Calculated Results for the Neutron Probe in

Water Without a Well Casing. . . . . . . . . . . . . . . . 2-8

2-3 Raman Spectrum From Pure, Solid Potassium Ferricyanide

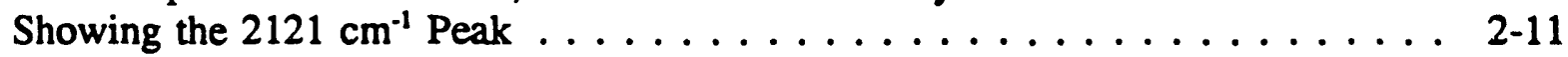

2-4 Raman Spectrum From Pure, Solid Sodium Ferrocyanide

Showing Peaks at 2049, 2072, And $2104 \mathrm{~cm}^{-1} \ldots \ldots \ldots \ldots \ldots \ldots$. . . . . . .

2-5 Scanning Thermogravimetric Analysis of 241-C-112

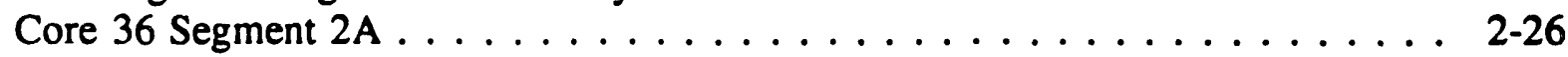

2-6 Differential Scanning Calorimetry of 241-C-112

Core 36 Segment 2 A . . . . . . . . . . . . . . . . . . . . 2-27

2-7 Ferrocyanide Tank Sample Analysis Flow Diagram . . . . . . . . . 2-45

2-8 Relative Concentration of Ferrocyanide in Solutions

Containing Potential Interferants Compared to

Ferrocyanide Measured in Standard Solution . . . . . . . . . . . . 2-47

2-9 Comparison of the Dissolution of Sodium Nickel

Ferrocyanide in Caustic Solutions Containing Sodium

Phosphate and Sodium Nitrate . . . . . . . . . . . . . . . . 2-48

2-10 Propagation Rates for Dried In Farm 1 Simulant as a

Function of Pressure and Initial Temperature $\ldots \ldots \ldots \ldots \ldots . \ldots . \ldots 2-54$

2-11 Confinement Test Chamber For Propagation and Aerosol Tests . . . . . . 2-56 


\section{LIST OF TABLES}

2-1 Cyanide, Carbon, Water, and Radioisotope Analyses for Tank 241-C-112 Core Samples . . . . . . . . . . . . . . . . 2-25

2-2 Heat of Reaction Values of 241-C-112 Core $34 \ldots \ldots$. . . . . . . . . . 2-29

2-3 Heat of Reaction Values of 241-C-112 Core $36 \ldots \ldots$. . . . . . . . . . . 29

2-4 Comparison of Parametric Pressure Related Propagation Rates . . . . . . . . 2-55

2-5 Material Collected from Aerosol Samples . . . . . . . . . . . . . 2-57

2-6 Gases Released from Ferrocyanide Simulant Reaction Tests . . . . . . . . . 2-57 


\section{LIST OF TERMS}

\begin{tabular}{|c|c|}
\hline ASC & Adiabatic Scanning Calorimetry \\
\hline CASS & Computer Automated Surveillance System \\
\hline CPAC & Center for Process Analytical Chemistry \\
\hline DNFSB & Defense Nuclear Facilities Safety Board \\
\hline DOE & U.S. Department of Energy \\
\hline DSC & Differential Scanning Calorimetry \\
\hline EA & Environmental Assessment \\
\hline EAL & Emergency Action Level \\
\hline EDTA & Ethylenediaminetetraacetic Acid \\
\hline FAI & Fauske and Associates, Inc. \\
\hline FFTF & Fast Flux Test Facility \\
\hline FSU & Florida State University \\
\hline FTIR & Fourier Transform Infrared \\
\hline FY & Fiscal Year \\
\hline HEDTA & Hydroxyethylenediaminetriacetic Acid \\
\hline HEPA & High-Efficiency Particulate Air \\
\hline HLW & High-Level Radioactive Waste \\
\hline HWVP & Hanford Waste Vitrification Plant \\
\hline IC & Ion Chromatography \\
\hline ICP & Inductively Coupled Plasma \\
\hline $\mathrm{JCO}$ & Justification for Continued Operations \\
\hline LANL & Los Alamos National Laboratory \\
\hline LL'NL & Lawrence Livermore National Laboratory \\
\hline LOW & Liquid Observation Well \\
\hline MCNP & Monte Carlo Neutron Photon [Model] \\
\hline MIT & Multifunctional Instrument Tree \\
\hline $\mathrm{NH}_{3}$ & Ammonia \\
\hline PNL & Pacific Northwest Laboratory \\
\hline PSO & Program Secretarial Officer \\
\hline RL & U.S. Department of Energy, Richland Field Office \\
\hline RSST & Reactive Systems Screening Tool (Small FAI Caiorimeter) \\
\hline SA & Safety Assessment \\
\hline SAR & Safety Analysis Report \\
\hline SEM & Scanning Electron Microscopy \\
\hline SRL & Savannah River Laboratory \\
\hline SST & Single-Shell Tank \\
\hline STG & Scanning Thermogravimetry \\
\hline TAMMO & Tank Moisture Model \\
\hline TAP & Tanks Advisory Panel \\
\hline TC & Thermocouple \\
\hline TD & Technology Development \\
\hline
\end{tabular}




\section{LIST OF TERMS (Continued)}

TGA

TLV

TMACS

TOC

Tri-Party Agreement

TTP

USQ

VSP

Westinghouse

Hanford

XRD
Thermogravimetric Analysis

Threshold Limit Value

Tank Monitoring and Control System

Total Organic Carbon

Hanford Federal Facility Agreement and Consent Order

Technical Task Plan

Unreviewed Safety Question

Vent Sizing Package (Large FAI Calorimeter)

Westinghouse Hanford Company

$\mathrm{X}$-ray Diffraction 


\section{QUARTERLY REPORT ON DEFENSE NUCLEAR FACILTIES SAFETY BOARD RECOMMENDATION 90-8 FOR THE PERIOD ENDING MARCH 31, 1993}

\subsection{INTRODUCTION}

\subsection{PURPOSE}

This quarterly report provides a status of the activities underway at the Hanford Site on ferrocyanide waste tank safety issues, as requested by the Defense Nuclear Facilities Safety Board (DNFSB) in their Recommendation 90-7 (FR 1990). In March 1991, a DNFSB Implementation Plan (Cash 1991) responding to the six parts of Recommendation 90-7 was prepared and sent to the DNFSB. The plan was revised and forwarded to the U.S. Department of Energy (DOE) in December 1992 for transmittal to the DNFSB (Borsheim et al. 1992). All of the activities in the revised DNFSB Implementation Plan are underway, and the status of each is described in Section 2.0 of this report.

\subsection{QUARTERLY HIGHLIGHTS}

- Thermocouple (TC) trees were installed in tanks 241-BY-111 and 241-BY-112. The thermocouple tree in tank 241-BY-111 was stopped by a hard object two feet, nine inches from the bottom. Westinghouse Hanford personnel are assessing the impact of this problem and are addressing options for remediation.

- Limited moisture simulant drums for neucron probe evaluation were completed. Initial benchmarking efforts show excellent agreement between modeling predictions and experimental results.

- The damaged laser diode source for the Raman system that is being developed at Westinghouse Hanford's 222-S laboratory was repaired. Testing and operation of the system is in progress. Analytes that represent components found in most of the saltcake wastes or ferrocyanide tank wastes are being archived for qualitative analysis.

- A Raman technology workshop was held at Hanford January 13-15, 1993, with Raman and spectroscopy experts from Lawrence Livermore National Laboratory (LLNL), Los Alamos National Laboratory (LANL), Savannah River Laboratory (SRL), Florida State University (FSU), Pacific Northwest Laboratory (PNL), and Westinghouse Hanford in attendance. The workshop was sponsored by the DOE Office of Environmental Restoration and Waste Management, and addressed 
technical issues related to Raman systems. The consensus opinion was that Raman is the most likely candidate for successful speciation of Hanford's waste tank constituents.

- A contract was established with the University of Washington's Center for Process Analytical Chemistry (CPAC) to complete an initial evaluation of the potential for measuring saltcake surface moisture with infrared techniques.

- The final FSU report summarizing FY 1992 contract work was cleared for public release. The report concludes that Raman spectra are not strongly impacted by $\mathrm{pH}$ and fluorescence interference, and that characterization by Raman spectroscopy is feasible.

- A document (WHC-EP-0648) discussing the probability of a hot spot within the ferrocyanide tanks will be publicly released by April 30, 1993. The report concludes that the existence or formation of a hot spot is incredible. The report further states that the probability of hot spots existing is too low to warrant the use of infrared scanning to detect potential hot spots.

- A data interpretation report for tank 241-C-112 was prepared. Heat of reaction values for the waste were at least a factor of ten lower than those predicted by ferrocyanide waste simulants. The highest heat of reaction observed was -8.6 $\mathrm{cal} / \mathrm{g}$ of dry waste. Propagating reactions are precluded in material with less than $-100 \mathrm{cal} / \mathrm{g}$ heat of reaction. Based on the two core samples extruded, the report concludes that the waste in tank 241-C-112 cannot support a propagating reaction, even when dry. The report should be ready for public release by April $30,1993$.

- Preliminary analytical results from core samples of tank 241-C-109 have shown low heat of reaction values. Only one core segment exhibited any exothermic activity and the rest of the samples contained a moderate to large endotherm in the temperature range where a ferrocyanide exothermic peak was expected. The tank 241-C-109 material appears to be no more reactive than tank 241-C-112 waste, even though it contains less moisture. Completed analytical data packages for tank 241-C-109 results are expected by April 30, 1993.

- A report on simulant characteristics, Ferrocyanide Waste Simulant Characterization (WHC-EP-0631), was cleared for public release in January 1993. Adiabatic calorimetry and reaction propagation rate tests on the ferrocyanide waste simulants have shown that sustained reactions cannot occur in waste containing more that $12 \mathrm{wt} \%$ unbound water. Experiments have also demonstrated that greater than $13 \mathrm{wt} \%$ ferrocyanide is required to sustain a propagating reaction. 
- A proposed plan for closure of the Ferrocyanide Unreviewed Safety Question (USQ) was transmitted to DOE in January 1993. The plan is based upon the fact that the ferrocyanide waste is very moist, and the energy release for ferrocyanide/ nitrate reactions is much less than the latent heat of vaporization for water.

- Pumping of tank 241-T-101 commenced on March 12, 1993, after authorization was granted by DOE. This tank was declared an assumed leaker in October 1992. Tank 241-BX-111 was also declared an assumed re-leaker at the end of the quarter.

\subsection{REPORT FORMAT}

The quarterly report on progress of activities under each of the six parts of DNFSB Recommendation 90-7 is arranged in the same order as in the original DNFSB Implementation Plan (Cash 1991) and the revised DNFSB Implementation Plan (Borsheim et al. 1992). The arrangement also follows the same order provided in the recommendation. To report on progress, each part of the recommendation is repeated in italics, followed by one or more paragraphs explaining the scope of work on each part or subpart of the recommendation. Subheadings for each task activity report the following items of progress:

- Progress During Reporting Period

- Planned Work for Subsequent Months

- Problem Areas and Action Taken

- Milestone Status.

\subsection{BACKGROUND}

Radioactive wastes from defense operations have accumulated at the Hanford Site in underground waste tanks since the early 1940s. During the 1950s, additional tank storage space was required to support the Hanford Site defense mission. To obtain this additional storage volume within a short period of time, and without constructing additional storage tariks, Hanford Site scientists developed a process to scavenge radiocesium and other soluble radionuclides from tank waste liquids. In implementing this process, approximately 140 metric tons of ferrocyanide were added to 24 single-shell tanks (SSTs).

Ferrocyanide is a complex of ferrous ion and cyanide that is considered nontoxic because it is stable in aqueous solutions. However, in the presence of oxidizing materials, such as nitrates/nitrites, near-stoichiometric amounts of ferrocyanide can be made to explode under special conditions in the laboratory by (1) heating it to high temperatures (above $285^{\circ} \mathrm{C}$ ); or (2) by an electrical spark of sufficient energy to heat the mixture. The explosive nature of 
ferrocyanide in the presence of an oxidizer has been known for decades, but the conditions under which the compound can undergo an uncontrolled exothermic reaction have not been thoroughly studied. Because the scavenging process involved precipitating ferrocyanide from solutions containing nitrate and nitrite, it is likely that an intimate mixture of ferrocyanides with nitrates and nitrites exists in parts of some of the SSTs.

Efforts have been underway since the mid-1980s to evaluate the potential for a ferrocyanide explosion in the Hanford Site single-shell tanks (Burger 1989; Burger and Scheele 1988). In 1987, the final environmental impact statement for disposal of Hanford Site waste farms was issued (DOE 1987). The environmental impact statement projected that the bounding "worstcase" accident in a ferrocyanide tank would be an explosion resulting in a subsequent shortterm radiation dose to the public of approximately 200 mrem.

A General Accounting Office study (Peach 1990) postulates a greater "worst-case" accident, with independently-calculated doses one to two orders of magnitude greater than the 1987 DOE environmental impact statement. A special Hanford Site Ferrocyanide Task Team was commissioned in September 1990 to address all issues involving the ferrocyanide tanks, including the consequences of a potential accident. On October 9, 1990, Secretary of Energy James $D$. Watkins announced that a supplemental environmental impact statement would be prepared containing an updated analysis of safety questions for the Hanford Site single-shell tanks (including a ferrocyanide explosion) (DOE 1990).

Using process knowledge and hintorical records, 24* tanks were identified at the Hanford Site as containing $1,000 \mathrm{~g}$-mole or more of ferrocyanide as the $\mathrm{Fe}(\mathrm{CN})_{6}^{-4}$ radical. In October 1990, the ferrocyanide issue was declared an Unreviewed Safety Question** because the safety envelope for these tanks may no longer be bounded by the existing safety analysis report (Bergmann 1986) and the 1987 DOE environmental impact statement. Work in and around any of the ferrocyanide tanks requires detailed planning, together with the preparation

*Two more tanks potentially containing ferrocyanide were identified since the DOE responded to Recommendation 90-7 (FR 1990) in November 1990.

**An Unreviewed Safety Question, as defined by DOE Orders 5480.5 (DOE 1986) and 5480.21 (DOE 1991), follows. "A proposed change, test or experiment shall be deemed to involve an Unreviewed Safety Question if:

- The probability of occurrence or the consequences of an accident or malfunction of equipment important to safety, evaluated previously by safety analysis will be signif:cantly increased, or

- A possibility for an accident or malfunction of a different type than any evaluated previously by safety analysis will be created which could result in significant safety consequences." 
of supporting safety and environmental documentation, and approval by DOE management. These restrictions are required for safety, and significantly increase the time required to complete work or install equipment in the tanks. See also Section 2.4.6. 
WHC-EP-0474-8

This page intentionally left blank. 


\subsection{DEFENSE NUCLEAR FACILTTIES SAFETY BOARD IMPLEMENTATION PLAN TASK ACTIVITIES}

The revised DNFSB Implementation Plan (Borsheim et al. 1992) addresses each task activity that was established in response to the six parts of DNFSB Recommendation 90-7. In this plan, each part of the recommendation is stated, and the progress of Hanford Site activities relating to that part is then described.

\subsection{DEFENSE NUCLEAR FACILITIES SAFETY BOARD RECOMMENDATION 90-7.1 (ENHANCED TEMPERATURE MEASUREMENT)}

"Immediate steps should be taken to add instrumentation as necessary to the SSTs containing ferrocyanide that will establish whether hot spots exist or may develop in the future in the stored waste. The instrumentation should include, as a minimum, additional thermocouple trees. Trees should be introduced at several radial locations in all tanks containing substantial amounts of ferrocyanide, to measure the temperature as a function of elevation at these radii. The use of infrared techniques to survey the surface of waste in tanks should continue to be investigated as a priority matter, and on the assumption that this method will be found valuable, monitors based on it should be installed now in the ferrocyanide bearing tanks."

\subsubsection{Instrument Trees}

DNFSB Recommendation 90-7.1 requested that actions be taken to add instrumentation to the ferrocyanide waste tanks, in order to determine if hot spots exist or may develop.

A strategy was initially developed to provide the temperature instrumentation necessary to monitor conditions in five high concern waste tanks on an expedited basis. The strategy was to (1) repair the existing TCs (where possible); (2) install new TC trees that would be fabricated from existing drawings; and (3) install multifunctional instrument trees (MITs) in those tanks that have a limited number of risers available. The MITs would provide temperature monitoring, the capability for gas sampling at three elevations, possible pressure monitoring, and access, if desired, for deployment of fiber optics inside the tanks. The TC trees would provide temperature monitoring but would not provide the option to obtain any other needed data. This strategy was later revised to include only repair of existing TC trees and installation of new TC trees in ferrocyanide waste tanks. No MITs will be installed in these tanks at this time. 
- Progress During This Reporting Period. Installation of thermocouple trees into tanks 241-BY-111 and -112, two of the last six non-leaking ferrocyanide tanks, was completed. The TC tree in tank 241-BY-111 stopped two feet, nine inches from the bottom of the tank when it hit either a hard waste layer or a failed piece of equipment. An evaluation will be made as to whether the TC will be adequate for monitoring.

As reported last quarter, an ultra high-pressure boring head for TC tree installation was designed and tested. Results indicate that it is possible to install a TC tree through $20 \mathrm{ft}$ of hard saltcake using less than 100 gallons of water, without generating an unacceptable quantity of aerosols. Final design of the ultra high-pressure concept was completed.

Planning was started for the assumed-leaker thermocouple tree installations. Safety documentation that supports installation of TC trees into the 14 assumed leaker ferrocyanide tanks was completed and transmitted to DOE for approval. The environmental assessment will be completed and also will be transmitted.

- Planned Work for Subsequent Months. Six new TC trees have been installed in the following ferrocyanide tanks (to date): 241-BY-104, -110, $-111,-112$, 241-C-109, and -112. Installations of TC trees in the last four non-leaking ferrocyanide tanks will be completed by July 30, 1993.

An acceptance test will be completed for the ultra high-pressure system to verify that the final hardware performs as expected prior to being turned over to Tank Farm Operations for field use.

- Problem Areas and Action Taken. To install equipment such as TC trees into waste tanks, water is normally used to sluice in the equipment to the desired depth. Water additions to ferrocyanide tanks that are classified as assumed leakers raise an environmental issue of whether waste could leak from the tank. The next four tanks to receive new TC trees are listed as sound; however, 14 of the 24 ferrocyanide tanks are classified as assumed leakers. It is feasible to reduce the amount of water used to install thermocouple trees to an acceptable amount using the high pressure bore head. This alternative concept was designed and tested. 
- Milestone Status.

- May 29, 1992: Install first new TC tree in a ferrocyanide tank, and three additional TC trees by September 30, 1992. The first installation was delayed because the safety and environmental documentation took longer than anticipated for review by DOE and Westinghouse Hanford. The first new TC tree was installed in September 1992.

- September 30, 1992: Install additional TC trees in three ferrocyanide tanks. Three additional TC trees were installed in September 1992 (total of four new TC trees).

- March 30, 1993: Submit safety and environmental documentation to DOE for installation of TC trees in assumed leaker ferrocyanide tanks. The SA was completed and transmitted on April 5, 1993. The EA will be finalized and also transmitted in April.

- July 30, 1993: Complete installation of an additional six TC trees in non-leaker tanks. Two of the six were installed in March. This milestone remains on schedule.

- September 30, 1994: Complete installation of 14 TC trees in assumed leaker tanks.

\subsubsection{Upgrades to Existing Tank Temperature Monitoring Instrumentation}

This task determined the operability and accuracy of presently installed TCs in the 24 ferrocyanide tanks at the Hanford Site. Existing TCs will be used to provide temperature readings for the ferrocyanide tanks, along with the new $\mathrm{TC}$ trees as they are installed.

Field measurements were taken on each TC in the existing trees to determine the resistance and voltage across the junction and across each lead to ground. The exact condition of each TC was determined by the resistance and voltage measurements (Bussell 1991). This work was completed in FY 1991 with a total of 265 TCs being evaluated. Work in FY 1992 focused on repair and recovery of 92 TCs that were found to be failed or marginal in performance.

- Progress During the Reporting Period. No progress was required or planned.

- Planned Work for Subsequent Months. None.

- Problem Areas and Actions Taken. None. 
- Milestone Status. This task is considered to be complete.

- March 31, 1992: Complete repair of TC elements, as appropriate, on selected ferrocyanide tanks. Only those TC elements in the waste, and occasionally one or more elements in the vapor space, are slated for repair. The original milestone was delayed because of other high priority safety work and tank farm entry restrictions. This milestone was completed in September 1992.

\subsubsection{Alternate Monitoring Technologies}

2.1.3.1 Infrared Scanning System. Infrared systems are commercially available from numerous vendors. These systems are sensitive to changes of $\pm 0.28{ }^{\circ} \mathrm{C}\left(0.50^{\circ} \mathrm{F}\right)$ or less under ideal conditions, and they may prove to be beneficial for mapping surface temperature profiles in the ferrocyanide tanks. Thermal modeling performed on ferrocyanide tank 241-BY-104 suggested that, if hot spots with temperatures of concern are possible, surface temperature differences might be great enough to be detected by infrared mappin'

One drawback of an infrared camera is the limited life caused by gamma radiation exposure to the semiconductor components within the scanner. Based upon an average radiation level within the SSTs of $150 \mathrm{R} / \mathrm{h}$, the useful life of an infrared camera may be limited to approximately 100 hours. Therefore, deployment for surface monitoring would have to be done periodically, perhaps monthly or bimonthly, unless tank anomalies dictate otherwise.

- Progress During Report Period. The comments received from DOE requiring changes to the infrared scanning report (Efferding et al. 1992) were incorporated into a new report (WHC-EP-0593). This predecisional report was released to DOE-RL on January 15,1993 . The conclusions in this report remained the same. In addition, work was performed evaluating the need for further IR scanning (see Section 2.1.4).

- Planned Work For Subsequent Months. Incorporate DOE comments into the report. Complete position paper on the credibility of hot spots and the need for infrared scanning.

- Problem Areas and Action Taken. None.

- Milestone Status.

- April 10, 1992: Completed infrared scan of tank 241-S-110. The scan was completed on April 21, 1992, after several delays caused by mechanical and weather-related problems. 
- May 29, 1992: Complete a report on the infrared scan of a non-Watch List tank. The report was completed on schedule. DOE comments were incorporated and the document resubmitted on January 15, 1993.

- December 31, 1992: Incorporate comments received on report of infrared monitoring of non-Watch List tank 241-S-110 and issue a revised report. The milestone was missed because other safety issues required immediate attention. The report was issued to RL as a predecisional document on January 15, 1993.

- April 15, 1993: Make a decision on whether infrared scans will be performed in selected ferrocyanide tanks.

2.1.3.2 In Situ Tank Moisture Monitoring. Determination of moisture concentrations in the ferrocyanide waste tanks will be pursued using data analysis and available surveillance systems. An existing neutron probe enhanced for well-logging and computer modeling are being used to determine information about moisture levels, material interfaces, and other waste characteristics. The probe would be used primarily to determine the axial moisture concentration profile within the ferrocyanide tanks.

Moisture measurement using neutron diffusion is an established technology. The technique uses a neutron source and one or two neutron detectors. Thermal neutrons originate as fast neutrons from the source and are slowed or absorbed by the medium. Because hydrogen atoms are effective at slowing down neutrons, the countrate of the detector is a strong function of the surrounding moisture.

The response of an active neutron probe to variations in the moisture content of the surrounding material depends primarily upon the distance between the detector and the neutron source. For short separation distances (near field), the observed countrate increases with increasing moisture content. For longer separation distances (far field), the observed countrate decreases for the same conditions. In the well-logging industry, the ratio of near field to far field countrate is used to determine moisture concentrations.

The existing neutron probe was designed to permit adjustment of source-to-detector separation distance. Experiments are being conducted with increased source-to-detector spacing using a stainless steel extender. A computer model is used to investigate the change in detector countrates as a function of the moisture content of the waste.

- Progress During Reporting Period. The Tank Moisture Model (TAMMO) computer code that characterizes neutron scans was developed. A supporting document will be written to describe the development and possible uses of this data modeling code. To date, the code has been applied to data from test scans of tank 241-BY-104 using the probe with and without an extender. The code successfully characterized the neutron scans using the same interfaces. With the 
scans characterized, the regions between the interfaces can be compared more easily. Because the scans are divided into homogenous regions, large numbers of Monte Carlo Neutron Photo (MCNP) code calculations of probe response to interfaces are not necessary.

Data were collected from limited moisture standards this quarter using the neutron probe and the drywell van surveillance system (see Cash et al. 1993). The standards consisted of 314 liter ( 83 gallon) overpack drums containing a moisture absorbing material. Countrates were acquired using an extender for two source-to-detector separation distances at several heights in the standards. To represent tank conditions, the probe was deployed into the standards through an unused length of fiberglass LOW. Because of the shortage of available LOW material, the standards were equipped with a 1/8-inch-thick aluminum pipe to allow the LOW to be moved from drum to drum. Five standards were fabricated; three contained moisture concentrations of 6, 15, and $30 \mathrm{wt} \%$ water; and two contained just water. One of the latter standards did not contain an aluminum sheath (Figure 2-1).

Benchmarking experiments were conducted using the moisture standards. Countrates were acquired with five source-to-detector spacings to establish a curve of countrate versus extender length. Parameters were varied until excellent agreement between the model results and the measured data was obtained.

Figure 2-2 shows a comparison of the measured results with the final MCNP calculated results. The reported errors on the MCNP results are within the statistical uncertainty of each point.

The primary evaluation of the moisture standard benchmarking data strongly suggested that the boron content of the LOW material is different from the vendor's specifications. Boron is a highly efficient neutron absorber and even a small amount affects probe performance. This effect can be compensated for if the boron concentration is known. Therefore, the boron content will be determined by combining experimental data with computer modeling. Analyses by the Westinghouse Hanford Analytical Laboratory are also being made.

To determine the boron content in the LOW, the sheathless pure water barrel is being modeled. The only introduced unknown is the LOW material. The LOW boron content is adjusted in the computer model in an attempt to obtain agreement between the calculated countrate and the experimental data. Boron content determination by this method is continuing. The other four simulant barrels will then be modeled using the LOW boron concentration determined experimentally. 
Figure 2-1. Geometry of Limited Moisture Standards Containing an Aluminum Sheath.

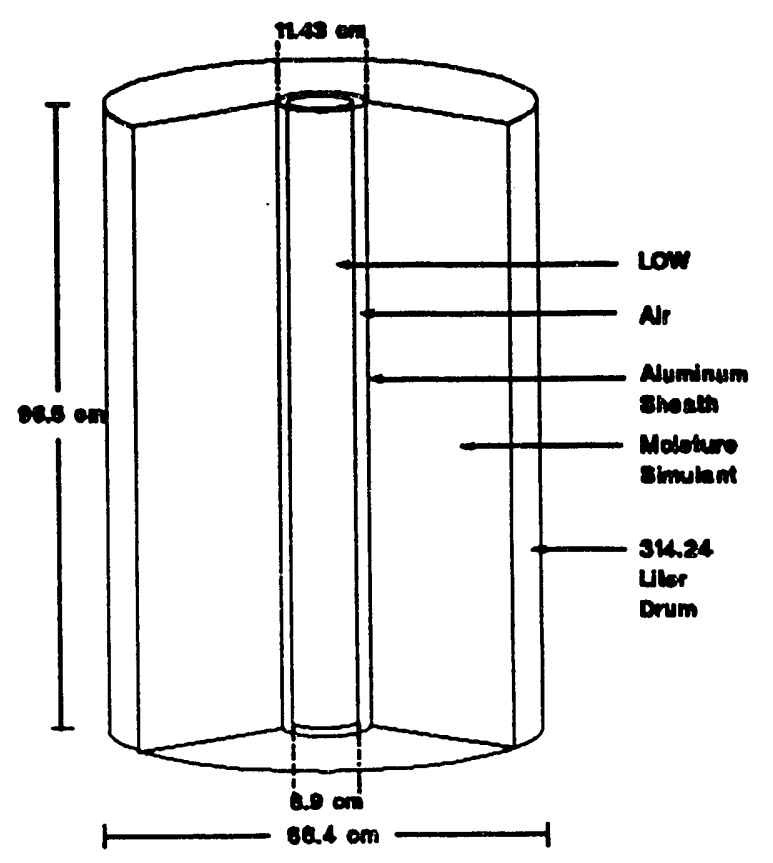

This quarter, the DOE Richland Field Office (RL) requested Westinghouse Hanford to prepare a white paper on various methods for measuring moisture in the ferrocyanide tanks. A draft of the paper was prepared and is currently being reviewed. This paper is scheduled for transmittal to DOE-RL by April 30, 1993.

- Planned Work for Subsequent Months.

The benchmarking effort will be completed by comparing predictions made by the probe model with all experimental data available from the moisture barrels. After the computer model is adequately benchmarked, the overall capability of the probe to determine moisture concentrations will be evaluated. The need to design a new single or dual detector probe will also be evaluated.

The TAMMO computer code will be used to characterize all available ferrocyanide tank neutron scans into interfaces and homogeneous regions. MCNP calculations will then be used to estimate the volume percent moisture of the regions. Moisture weight percents can then be calculated using tank waste density values.

A report evaluating the need, alternatives, and problems associated with moisture monitoring will be completed. 
Figure 2-2. Benchmarking Comparison of Measured Data With MCNP Calculated Results for the Neutron Probe in Water Without a Well Casing.

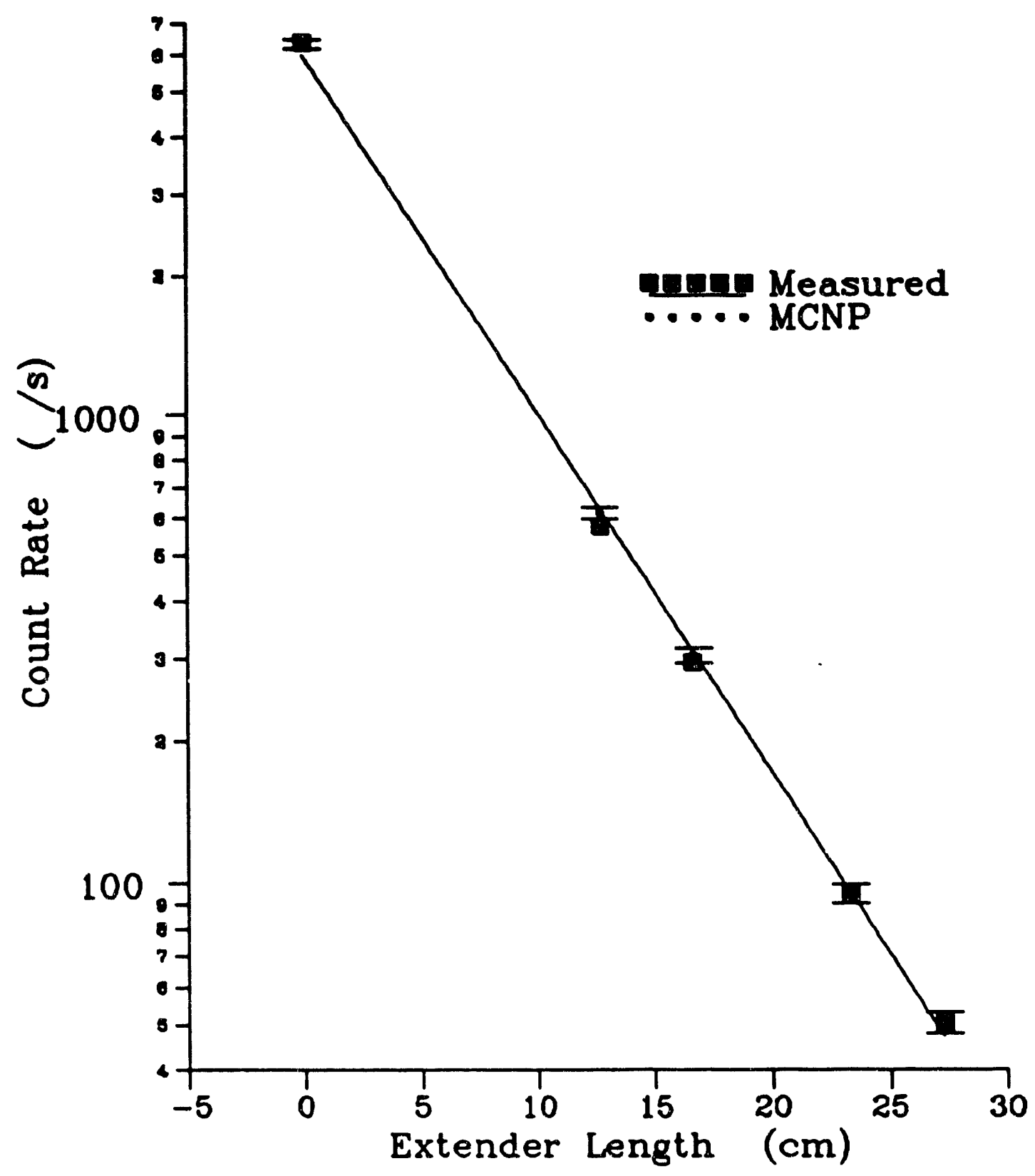


Neutron test scans were performed in four of the twelve ferrocyanide tanks with LOWs. Neutron test scans will continue to be performed in the eight remaining ferrocyanide tanks with LOWs.

- Problem Areas and Action Taken.

The LOW used in the barrels has an inside diameter of 2.98 inches, and the procurement specifications quote a 3.1 inch inside diameter. This discrepancy causes a large uncertainty in the boron content of the LOWs in the tanks and consequently in the modeling efforts. Several methods to determine the LOW boron content are underway, as discussed above.

- Milestone Status.

- September 30, 1992: A letter report was completed documenting the current status of Monte Carlo calculations, tank 241-B-104 test scans, and the increased understanding of the neutron probe. The report also included a description of recommended tasks to be performed, including field activities.

- December 1, 1992: Completed neutron probe test scans of tanks 241-BY-101, -104, -105, and -106 using the modified neutron probe.

- March 29, 1993: Limited moisture simulant drums were completed and available for benchmarking efforts.

- April 30, 1993: Transmit a white paper to DOE for review that describes various methods for moisture measurement and the advantages and disadvantages of each system.

- June 25, 1993: Complete limited calibration using special simulant-filled drums as standards.

- September 27, 1993: Transmit a comprehensive proof-of-principle final report to DOE.

2.1.3.3 Waste Analysis With Laser Raman Spectroscopy. The objective of this work is to investigate the use of Laser Raman spectroscopy for detecting and quantifying cyanide species (ferrocyanide, ferricyanide, and free cyanide) in Hanford Site high-level waste tanks. Based on successful feasibility work, the goal is to develop in situ or ex situ methods for characterizing these tank wastes. Raman spectroscopy would then be pursued for other anions of interest (such as sulfate, nitrate, nitrite, phosphate, and aluminate) and for organic compounds such as ethylenediaminetitraacetic acid (EDTA) and hydroxyethylenediaminetriacetic acid (HEDTA). 
Screening studies are being conducted to evaluate the Raman method with simulant and surrogate waste tank materials in cold tests. Tests with actual waste tank materials are also planned. Possible interference could come from the presence of organic and inorganic decomposition products in the waste matrix. The fluorescence of the products caused by the excitation from the incident laser light could possibly overwhelm the Raman backscatter unde: certain conditions. The effect of high $\mathrm{pH}(>8)$ on ferrocyanide signal strength and frequency position will be studied. Tests to establish detection limits, accuracy, and precision for ferrocyanide in the presence of other components are underway. The hot cell work is being pursued as an interim application to direct waste tank use. One interim application is as a low accuracy screening tool that would indicate homogeneity along the axis of an extruded waste tank core. This would provide sampling guidance for detailed analytical chemistry work.

- Progress During Reporting Period. The damaged laser diode source at the Westinghouse Hanford 222-S laboratory was repaired; testing and operation of the system is in progress. Raman system calibration and performance tests will be completed to bench-mark the system prior to hot cell installation. The Raman system is presently operating with spectral slits at 200 microns, producing reasonable optical throughput and wavelength resolution. Analytes that represent components found in most of the saltcake wastes or ferrocyanide tank wastes are being archived for qualitative analysis. Examples of the systems performance are illustrated by the Raman spectra for pure potassium ferrocyanide and sodium ferrocyanide that are shown in Figures 2-3 and 2-4.

Spectra of phosphates and the mononickel salts of both sodium and cesium ferrocyanide were very difficult to obtain because of low signal responses. The potential of moving to a shorter stimulation wavelength will be considered (i.e., an argon ion laser) as Raman responses are proportional to the inverse of the fourth power of wavelength. Additional effort will be applied to address issues associated with power density and wavelength on ferrocyanide materials.

Qualitative calibration of the system is continuing. New linear dispersion profiles will be calculated for the $820.6 \mathrm{~nm}$ laser source wavelength. In addition, a laser power profile with Raman scattering intensity from nitrite will be generated as a means to measure laser power in the hot cell.

A final draft of a hot cell test plan was completed and will be reviewed. This provides guidance for Raman work with surrogates, pure materials, and actual tank wastes in the hot cell tests.

A Raman technology workshop was held at Hanford January 13-15, 1993, with Raman and spectroscopy experts from LLNL, LANL, SRL, FSU, PNL, and Westinghouse Hanford in attendance. The workshop was sponsored by the DOE Office of Environmental Restoration and Waste Management and addressed 
Figure 2-3. Raman Spectrum From Pure, Solid Potassium Ferricyanide Showing The $2121 \mathrm{~cm}^{-1}$ Peak.

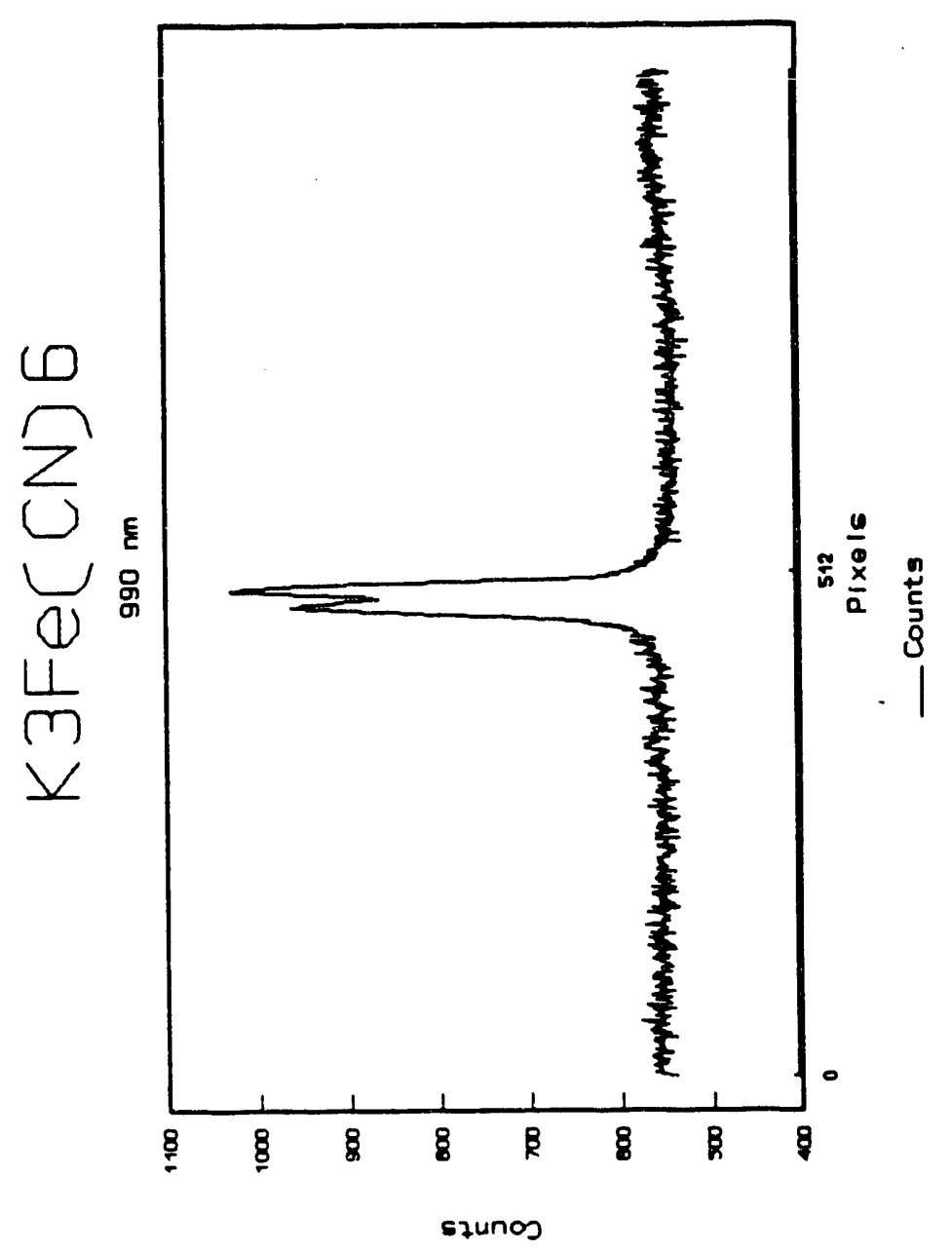


Figure 2-4. Raman Spectrum From Pure, Solid Sodium Ferrocyanide Showing Peaks At 2049, 2072, And $2104 \mathrm{~cm}^{-1}$.

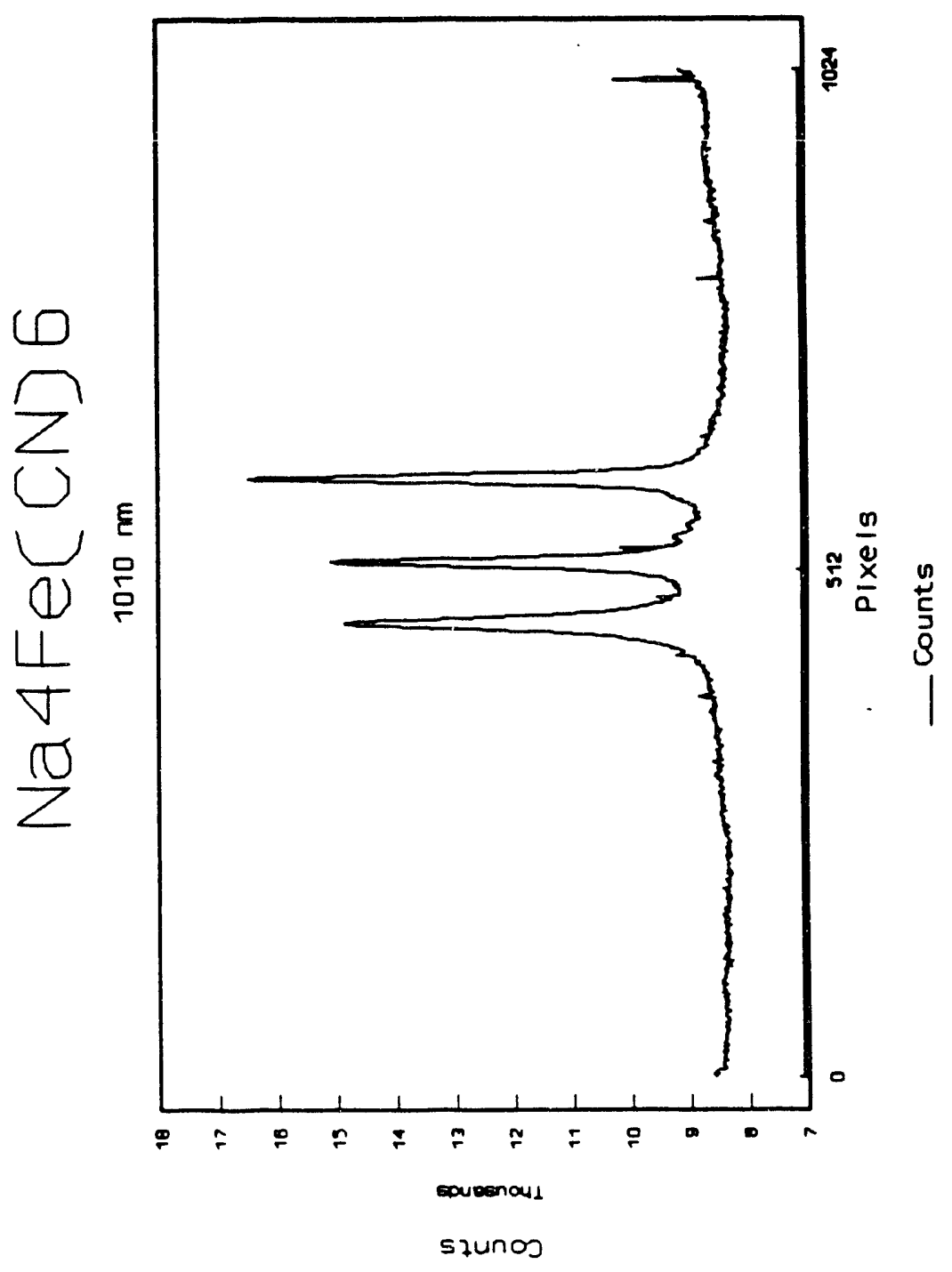


technical issues related to Raman systems. The consensus opinion was that Raman is the most likely candidate for successful speciation of Hanford's waste tank constituents. Five technical topic areas were covered: (1) chemical speciation; (2) qualification plan; (3) probe analysis; (4) irradiation data; and (5) Raman system optimization.

A contract was established with the University of Washington's Center for Process Analytical Chemistry (CPAC) to complete an initial evaluation of the potential for measuring saltcake surface moisture with infrared techniques. This technology has been commercially applied to food grain, potato, and dairy products. CPAC helped design an infrared moisture sensing system to monitor water content in cookie dough.

The near-infrared systems being investigated by SRL would support a surface moisture measurement system. The FY 1994 Technology Development (TD) Technical Task Plan (TTP) guidance included the preparation of a requirements document for a deployred Hanford hot cell spectroscopy system. This document was prepared and delivered to SRL for their use in the assessment of the environmental ruggedness of these systems per their TTP guidance.

The final FSU report summarizing FY 1992 contract work, WHC-SD-TD-RPT-003, was cleared for public release. The report contains archive spectra of pure materials (e.g., ferrocyanides, ferricyanides, nitrates, nitrites, and sulfates) of concern to Waste Tank Safety. It also shows that Raman spectra are not strongly impacted by $\mathrm{pH}$ and fluorescence interference. The report documents positive feasibility for using Raman spectroscopy for characterization.

A contract extension was placed with FSU to expand the Raman investigations to ferrocyanide speciation and generation of exploratory Raman spectra from selected waste constituents.

A surrogate selection workshop was held to select target tanks and waste materials for waste tank characterization and sensing applications. This workshop supports ongoing and planned work in remote sensing for moisture, organics, and elemental species.

- Planned Work For Subsequent Months. Complete the non-radioactive erivironment benchmark testing, calibration, and spectra archival work with the existing Raman system.

Install the Raman system in a hot cell and initiate Raman system tests. Acquire Raman data from test and calibration materials, and from actual tank waste materials. 
Supply CPAC with a saltcake simulant representative of tank 241-BY-104 for infrared work in surface moisture sensing. This work will establish a basic technology for sensing surface moisture on saltcake surfaces.

Supply FSU with appropriate simulants for their Raman organics studies. This work expands the ferrocyanide studies into potential areas of organics for interference impacts and potential qualitative/quantitative measurement of organic content in tank waste materials.

Complementary work on Raman systems and spectroscopy will continue to be funded at SRL and LLNL by the DOE Office of Technology Development. These tasks will be integrated to provide the best synergistic effects for all involved.

- Problem Areas and Actions Taken. None.

- Milestone Status.

- May 1, 1992: Receive initial experimental data from FSU on tests using In Farm and U Plant simulants provided by Westinghouse Hanford. Data from FSU on these simulants was received on schedule.

- September 30, 1992: Receive interim report on initial data collection and validation methods for ferrocyanides/ferricyanides. This report was received October 27, 1992.

- December 31, 1992: The final FSU report on initial collection and validation methods with Raman techniques was issued in February 1993 as a publicly released document.

- December 31, 1992: An environmental specification document for a hot cell and waste tank deployable Raman system was issued on January 5, 1993. Clearance issues and holiday impacts caused a slight delivery delay.

- January 31, 1993: The FSU contract was renewed on April 3, 1993. Complications with scope, costs, and conditions delayed the extension of this contract.

- February 28, 1993: An environmental specification document for a hot cell and waste tank deployable spectroscopy system was issued on February 11, 1993. 
- August 31, 1993: Obtain Raman system performance data with actual tank waste materials.

- September 15, 1993: Demonstrate hot cell Raman spectroscopy.

\subsubsection{Hot Spot Thermal Modeling}

The decay of radioactive materials in Hanford Site waste tanks generates heat. A rapid chemical reaction within the ferrocyanide waste could occur if there is sufficient ferrocyanide concentrated and a high enough temperature is present to cause an exothermic excursion and local propagation. There is usually only one TC tree in each ferrocyanide tank*, and the trees are not always at the same location. Consequently, there is concern that heat generation could exist in these tanks and not be detected. This task models and analyzes the available temperature data from the ferrocyanide tanks in order to determine the heat load and temperatures as a function of depth and horizontal location. Sensitivity and parametric analyses are included to determine the magnitude of hot spots that might exist within the waste and still not cause a propagating reaction to occur.

State-of-the-art validated computer codes are used in the modeling. They are benchmarked with existing data and employ two- and three-dimensional capabilities. Both steady-state and transient models will be used.

- Progress During the Reporting Period. An analysis of tank 241-C-112 was completed. This analysis used the best available data on soil conductivities, which are an important boundary value. A duplicate analysis was conducted on the same tank using the older soil conductivity data in order to compare the results between the two cases. Heat loads calculated using the older conductivity values are low by a factor of two. A similar pair of analyses were conducted on tank 241-BY-104 with similar results. The analyses included comparing hotspot concentration factors. It was determined that, while the power levels and conductivities increased by a factor of two, the concentrations necessary to create a hotspot with a temperature of $120^{\circ} \mathrm{C}$ decreased by a factor of 0.85 .

A report will be released to the public discussing the probability of a hot spot within the ferrocyanide tanks that could raise the temperature to $120^{\circ} \mathrm{C}$, the approximate boiling point of the waste solution. This report uses the results of several analyses to describe the concentration factors required for such a hot spot, and the mechanisms for forming one. The latest work by Fauske and Associates, Inc. (FAI) was incorporated. The report concludes that the existence

*Exceptions are tanks 241-BY-104, -105, -110, -C-109, and -112, which have two TC trees. See Table A-1. 
or formation of a hot spot of this magnitude is incredible. The use of infrared scanning to detect both a postulated existing hot spot and a postulated forming hot spot is also discussed. While infrared scans of the tanks may produce useful information concerning the lateral heat distribution within the tank, the probability of hot spots actually existing is too low to warrant their use.

- Planned Work for Subsequent Months. Conduct analyses of selected tanks to determine their heat loads and the thermal conductivities of the waste within the tanks. The latest temperature data and soil conductivity values will be used, and a report of the analyses, cleared for public release, will be prepared and issued.

Complete hot spot thermal modeling analysis of a worst case ferrocyanide tank using the latest temperature data and soil conductivity values. Modeling will account for the transpiration of moisture away from the hot spot.

- Problem Areas and Action Taken. None.

- Milestone Status.

- July 31, 1992: Determined the heat loads and calculated thermal conductivities of the contents for tanks 241-BY-105, -106, -108, -110, -111 , and $-\mathrm{C}-109$. The upper and lower bounds of these parameters were calculated. The report on this work was delayed to September 30, 1992, to include additional work with thermal conductivities more representative of actual waste. A predecisional report on this work was completed.

- September 30, 1992: Performed a detailed thermal analysis of tank 241-BY-106 to determine the response of the tank contents to a hot spot of varying intensities. This analysis included both steady-state and transient analyses. A predecisional report was issued September 30, 1992.

- April 15, 1993: Perform detailed thermal modeling studies to (1) determine if there is enough likelihood for forming hot spots to warrant infrared scans of selected ferrocyanide tanks; and (2) issue a position paper report on whether hot spots of concern are credible.

- June 25, 1993: Complete thermal hydraulic analyses of four ferrocyanide tanks to determine heat loads and conductivities of the waste contents and issue a report that is approved for public release.

- September 30, 1993: Complete transient hot spot thermal modeling of a worst case ferrocyanide tank, taking into account transpiration of moisture away from the hot spot, and document the results in a report approved for public release. 


\subsection{DEFENSE NUCLEAR FACILITIES SAFETY BOARD RECOMMENDATION 90-7.2 (CONTINUOUS TEMPERATURE MONITORING)}

"The temperature sensors referred to above [Recommendation 90-7.1] should have continuous recorded readouts and alarms that would signal at a permanently manned location any abnormally high temperatures and any failed temperature instrumentation."

\subsubsection{Tank Monitoring and Control System}

This task will provide continuous monitoring of presently installed (and operable) TCs for the 24 ferrocyanide tanks. New TC trees, as they are added to each tank, will be connected to the system, resulting in continuous monitoring. All data are collected automatically at the continuously manned Computer Automated Surveillance System (CASS) Operator Control Station in the 2750E Building, 200 East Area. The monitoring system is independent of the CASS and capable of displaying data to an operator on request. Trend data on selected points is available for display in numeric or graphic form.

The system, which became operational in September 1991, has the capability to assign alarms for change in the value of any temperature point. Alarms, if they occur, trigger an audible annunciator and are logged immediately to hard copy. An alarm summary display provides a list of the most recent alarms in order of occurrence. Each alarm can be identified by point and time of occurrence. Operator acknowledgement of the alarm will silence the audible annunciator.

Signal conditioning and multiplexing are performed locally at each tank. This eliminates the need to transmit low-level signals to the tank farm boundary and reduces cable runs.

Electronic noise, extension wire corrosion, and thermal gradients are thereby reduced.

Five BY Farm tanks were connected to the system in September 1991, and an additional five in December 1991. These include tanks 241-BY-101, -103, -104, -105, -106, -107, -108, $-110,-111$, and -112 . Tank $241-\mathrm{BY}-105$ has two operating TC trees; both were connected the to the tank monitor and control system (TMACS). In April 1992, tanks 241-TY-101, $-103,-104$, and $241-\mathrm{TX}-118$ were connected to the system and are now operational. Two new TC trees installed in September 1992 in tanks 241-BY-104 and -110 have also been connected to the TMACS. This makes a total of 14 ferrocyanide tanks (17 TC trees) that are now monitored by the TMACS. Temperature readings from the working TCs in these tanks are being recorded continuously. The two new trees just installed (in tanks 241-BY-111 and -112) will be connected to TMACs in April.

- Progress During Reporting Period. The TMACs design for connecting two ferrocyanide tanks in T Farm and all of the C Farm tanks was completed. All 12 tanks in C Farm are being connected to the TMACS because this farm 
contains a number of Watch List tanks and is the primary farm of concern for vapor releases. Fabrication of field hardware for the $C$ Farm tanks starter' this quarter, and installation is scheduled for completion by July 30 . Design of the TMACS for BX Farm was started this quarter. There are four ferrocyanide tanks in this farm.

- Planned Work For Subsequent Months. The design for connection of the four ferrocyanide tanks in the BX Farm will be completed. Construction will begin in the BX, C, and T Farms to complete connection to the TMACS for those tank farms. New temperature trees installed in BY-111 and -112 will also be connected to the TMACS in April.

- Problem Areas and Action Taken. None

- Milestone Status.

- September 30, 1992: Completed design of the TMACS for C and T farms.

- July 30, 1993: Complete installation of the TMACS for the four ferrocyanide tanks in C Farm.

- August 30, 1993: Complete installation of the TMACS two ferrocyanide tanks in T Farm.

- September 30, 1993: Complete design and installation of the TMACS for the four ferrocyanide tanks in the BX Farm.

- September 30, 1993: Complete installation of the TMACS for new TC trees installed during FY 1993.

- September 30, 1994: Incorporate TMACS on new TC trees installed during FY 1994. 


\subsection{DEFENSE NUCLEAR FACIITIES SAFETY BOARD RECOMMENDATION 90-7.3 (COVER GAS MONITORING)}

"Instrumentation should also be installed to monitor the composition of cover gas in the tanks, to establish if flammable gas is present."

\subsubsection{On-Line Gas Monitoring}

Options for installing a gas monitoring capability on new TC trees will be reviewed. The use of a separate riser, possibly in conjunction with other equipment, to achieve an installed capability may be necessary. However, a definite decision to monitor continuously or have the installed capability for grab samples has not been made. The frequency of gas monitoring and/or the need for continuous monitoring will be determined after a significant number of the ferrocyanide tanks are vapor sampled, or if a concern is detected during the sampling program. Evaluation of gas samples secured to date for tanks 241-BY-104, -110, 241-C-109, -112, 241-T-101, and -107 has indicated no need to continuously monitor for specific gases.

\subsubsection{Interim Flammable Gas Monitoring}

The effort to conduct flammable and toxic gas monitoring and analyses in the 24 ferrocyanide tanks is continuing. This effort was transferred to the waste tank Toxic Vapor Program, which will coordinate interim gas monitoring of the ferrocyanide tanks. There is presently no plan to develop a cryogenic technique for vapor sample analysis. Therefore, Westinghouse Hanford ceased taking cryogenic samples from the ferrocyanide tanks. Tank vapor spaces are measured for flammability, and are monitored using an organic vapor monitor and Dräger tubes for toxic gases as required by the safety assessments for a particular activity. Development and validation of alternative technologies for vapor space characterization is in progress using Summa canisters and specific absorption tubes.

Because the safety issue associated with ferrocyanide tanks is listed as a USQ, this activity requires DOE-EM Headquarters Program Secretarial Officer (PSO) approval for performing sampling activities within the tanks. Although past sampling conducted by WHC Industrial Hygiene and Safety with a combustible gas monitor has indicated no flammable gas content above 6 percent of the lower flammability limit, no qualitative measurements were obtained. The combustible gas monitor is calibrated using pentane gas; readings are assumed to be for hydrogen gas, which is known to be present from radiolysis of water.

All 24 ferrocyanide tanks are passively ventilated through individual high-efficiency particulate air (HEPA) filters. The "breathing" is dependent upon changes in barometric pressure and differences in temperature between the waste tank and the outside air. The 
pressure change causes a small volume of stagnant air to be replaced with fresh air, which helps control the concentration of chemical vapors inside the tanks.

Initial vapor space gas samples were taken through two different risers and at three elevations for the first two ferrocyanide tanks (241-BY-104 and 241-C-112). The lowest elevation sample was about $25 \mathrm{~cm}(1 \mathrm{ft})$ above the waste surface, with one sample in the middle and one near the top of the dome space. Gas sampling criteria were defined and included identification of the chemicals to be monitored, detection limits, accuracy and precision of the analytical methods, and sample positions inside the tank. Vapor space gas samples were taken from one riser at three elevations in tanks 241-C-109 and 241-BY-110. Mobile Analytical Laboratory Testing (MALT) samples were also taken from tank 241-C-109 and archived for future analysis (if warranted).

- Progress During Reporting Period: Sampling of vapor space gases in ferrocyanide tank 241-T-101 was completed on February 24, 1993. The tank was sampled through one riser at three elevations. Analytical methods used included the combustible gas monitor for flammable gases, an organic vapor monitor (OVM) for organics, and Dräger tubes for hydrazine, ammonia, cyanides, hydrogen cyanide, and nitrous fumes, Field readings for the tank showed no concentrations of flammable gases above the baseline readings of the combustible gas monitor. The only compound detected by the Dräger tubes was ammonia at approximately $20.5 \mathrm{ppm}$ at each elevation(basic organic amines were also indicated). The OVM field readings were $1.8 \mathrm{ppm}$ at the highest sample elevation, and $2.1 \mathrm{ppm}$ at the other two elevations.

- Planned Work for Subsequent Months. Flammable gas sampling will be done, as required, to support planned core sampling and thermocouple installation. Once the Vapor Program validates a method for characterization of tank vapors, more extensive sampling will resume.

- Problem Areas and Action Taken. Since the validity of the toxic gas results obtained from the cryogenic gas sampler has been questioned, less sensitive methods will have to be used, such as Dräger tubes. However, they are adequate for worker safety. Gas sampling for potential gases of interest to the ferrocyanide program will be performed after improvement and validation of the sampling method is completed.

- Milestone Status.

- September 30, 1992: Complete flammable gas sampling of 241-C-109, 241-BY-110, and 241-T-107 to support push mode core sampling and thermocouple tree installation. Tank 241-C-109 was sampled on 
August 26, 1992. Tank 241-BY-110 was sampled on September 27, 1992. Tank 241-T-107 was sampled on October 22, 1992.

- September 30, 1993: Complete flammable gas sampling of eight additional ferrocyanide tanks to support push mode core sampling and TC tree installation. Tank 241-T-101 was sampled on February 24. 1993 to support in-tank sampling and interim stabilization (pumpout) of the tank. Tanks 241-BY-111 and -112 were sampled to support TC tree installation.

- March 31, 1994: Complete an evaluation report to determine which gases, if any, need to be continuously monitored on selected ferrocyanide tanks.

- September 30, 1994: Complete vapor space sampling of remaining ferrocyanide tanks, as required to support various field activities, and issue a final report approved for public release.

\subsubsection{Vapor Space Gas Modeling}

The possibility that localized concentrations or stratification of gases exist in the tanks continues to be evaluated. Radiolysis of water generates hydrogen, and the interaction of various chemicals in the tanks may also release hydrogen and other gases. Some of these gases may have the potential to be explosive or otherwise hazardous, if their concentrations become large enough and are mixed properly with air. This concern will be addressed through the sampling effort described above. A modeling effort to determine airflow patterns in the tank vapor space of tank 241-C-109 was conducted to evaluate the amount of mixing and local gas concentrations that could occur. The results of this analysis will be used to evaluate the hazards and risks involved during sampling and other intrusive activities within the tank. This work will aid in developing a methodology for performing future vapor space analysis for all ferrocyanide tanks.

The modeling study determined how the composition of the vapor space gases changes with time, and can be further used to predict the steady-state equilibrium values for gases of interest. Because the 24 ferrocyanide tanks are all passively ventilated, the vapor space gas composition is strongly dependent upon air flow through the tank, gas generation rates, waste temperature, convective mixing, and heat transfer out of the tank. Two state-of-the-art, validated computer codes (HEATING7 and GOTHIC) were useri in the modeling. These codes were validated using existing data and employ three-dimensional capabilities. 
An analysis of a second tank was deemed unnecessary because of the well-mixed environment calcuinted for the first tank. The results of this study have shown that the gases in the tank are well n:ired and follow Graham's law for gaseous diffusion.

- Progress During the Reporting Period. The tank 241-C-109 analysis report was completed and approved for public release on February 8, 1993. Results of the analysis show that there are no significant concentrations of hydrogen gas within the tank including the risers. The airflow velocities within the tank are low, but are sufficient to keep the tank dome space and tank risers well mixed. There is a transfer of gas to the atmosphere through the breather filter from barometric pressure changes in the atmosphere over time. This breathing is sufficient to prevent gas buildup within the tank and tank risers.

- Planned Work for Subsequent Months. The original goals were met and the task is considered to be complete.

- Problem Areas and Action Taken. None.

- Milestone Status.

- February 8, 1993. Perform an analysis of the airflow patterns in ferrocyanide tank 241-C-109. Determine the potential to have concentrations of fiammable gasses that could lead to hazardous conditions, and issue a report on the rindings. This report was completed and cleared for public release.

April 30, 1993. Complete an analysis, if warranted, of a second tank with greater differential temperatures within the tank and issue a report approved for public release. Status: This activity is not required because analysis of tank 241-C-109 has shown the gases to be well mixed.

\subsection{DEFENSE NUCLEAR FACILITIES SAFETY BOARD RECOMMENDATION 90-7.4 (FERROCYANIDE WASTE CHARACTERIZATION)}

"The program of sampling the contents of these tanks should be greatly accelerated. The proposed schedule whereby analysis of two core samples from each SST is to be completed by September, 19.98 is seriously inadequate in light of the uncertainties as to safery of these tanks. Furthermore, additional samples are required at several radii and at a range of elevations for the tanks containing substantial amounts of ferrocyanide." 


\subsubsection{Ferrocyanide Tank Waste Sampling and Characterization}

Characterization of the contents of the ferrocyanide tanks is necessary to (1) guide chemical reaction studies with ferrocyanide waste simulants; (2) provide a basis for estimating the consequences of a runaway ferrocyanide reaction; (3) determine how the ferrocyanide waste can be stored safely in situ until mitigation or remediation actions are completed; and (4) apply the study results to the final remediation of these tanks. Knowledge of the concentrations and relative positions of various waste constituents is also important to determine their potential for chemical reactions and the consequences of a potential reaction.

The important reactive materials present in the ferrocyanide tanks are fuel (ferrocyanides, sulfides, and reduced carbon species such as organic complexants); oxidants (nitrates and nitrites); and inerts or diluents (phosphates, aluminates, sulfates, carbonates, oxides, hydroxides, et al.). The location of fission products such as ${ }^{137} \mathrm{Cs}$ and ${ }^{90} \mathrm{Sr}$ is important because these products are heat sources that can raise and maintain the temperature of the tank contents. Their location is also important because they are potential source terms in postulated radiological releases from an exothermic ferrocyanide reaction. The water content of the waste is very important because the high heat capacity and the heat of vaporization of water make it an effective inerting material. Water content can prevent a sustained combustion or an explosion. Wet ferrocyanide material would require drying before it could react or propagate. Other materials (e.g., nickel, copper, lead, and the rare earths) may be important as potential catalysts.

The push-mode core sampling technique is presently the only viable Hanford Site method for waste tank core sampling, until it is demonstrated that rotary-drill core sampling will not produce excessive temperatures in the waste. Seven ferrocyanide tanks suitable for push-mode core sampling were placed on the list of SSTs to be core sampled in FY 1992 and FY 1993. Tank 241-C-112 was core sampled through three risers (two segments per core) in March 1992, and tank 241-C-109 was core sampled through three risers (one segment per core) in September 1992. Core sampling of tank 241-T-107 was completed in March 1993. Three risers were used to take four-segment cores (original plans were to take only two cores but sample recovery was poor from one of the risers).

Development and design work required to demonstrate that rotary-drill core sampling of a "harder" waste can be done without producing unacceptably high bit temperatures has now been completed, and the system is going through acceptance testing.

- Progress During the Reporting Period. The analytical data packages for the three tank 241-C-112 core samples were released by the Hanford Analytical Services Management organization early this quarter. A data interpretation report was prepared and will be reviewed by an independent peer review group (Data Evaluation Team). The major conclusion of the report is that the waste in tank 241-C-112 cannot support a propagating reaction, even when dry. The report should be ready for public release by April 30, 1993. 
Tank 241-C-112 was core sampled through three risers (cores 34, 35, and 36). Supernatant covered the solid waste in the tank. Each core was divided into quarter-segments representing approximately 4.75 inches of core sample. These quarter-segments, numbered 1C (top of waste) to 2D (bottom of waste), were analyzed individually and as composites. Volume recovery for core 34 was fair; quarter segments $1 \mathrm{C}$ and $2 \mathrm{~A}$ were missing. Volume recovery for core 35 was poor, only quarter segment 2D was recovered. Volume recovery for core 36 was good; all quarter segments were recovered.

Highlights of the data collected are presented in Table 2-1. A summary of the major analytes is presented in Appendix A (Table A-2). The wet waste solids are made up of approximately $53.8 \mathrm{wt} \%$ water. Total organic carbon and total cyanide $\left(\mathrm{CN}^{-}\right)$concentration averaged 0.3 and $0.4 \mathrm{wt} \%$, respectively. Cyanide values were substantially lower than concentrations predicted by process flowsheets.

Separate aliquots from each quarter-segment and composite were analyzed by gamma energy analysis and for ${ }^{90} \mathrm{Sr}$. The results for ${ }^{137} \mathrm{Cs}$ and ${ }^{90} \mathrm{Sr}$ are displayed in Table $2-1$. The ${ }^{137} \mathrm{Cs}$ was not soluble, as less than one wt\% was solubilized during a water leach experiment. There was a wide variation in the ${ }^{90} \mathrm{Sr}$ analyses, both between and within the cores. This variation is believed to be a result of strontium waste added to the tank from the strontium semiworks in the early 1960s. These additions were small in volume but relatively high in ${ }^{90} \mathrm{Sr}$. The concentrations shown for core 36 are believed to be representative of actual tank contents. The tank heat ioad calculated from the waste temperature profiles agrees more closely with this composite concentration.

Scanning thermogravimetric analysis (TGA) and differential scanning calorimetry (DSC) were performed on quarter-segment and core composite material obtained from tank 241-C-112. These two thermal analysis techniques are useful in determining the thermal stability or reactivity of a material. In DSC analysis, heat flow in excess of the usual heat capacity of the substance is measured while the substance is exposed to a linear increase in temperature. TGA measures the mass of a sample while the temperature of the sample is increased at a constant rate. 
Table 2-1. Cyanide, Carbon, Water, and Radioisotope Analyses for Tank 241-C-112 Core Samples.

\begin{tabular}{|c|c|c|c|c|c|c|}
\hline SAMPLE & $\begin{array}{l}\text { TOTAL } \\
\text { CYANIDE } \\
\left(m(x)^{1}\right.\end{array}$ & $\begin{array}{l}\text { TOTAL OROANIC } \\
\text { CARBON } \\
\text { (wx) }\end{array}$ & $\begin{array}{l}\text { TOTAL OROANIC CARBON + } \\
\text { TOTAL NOROAMIC CARBON } \\
\text { (mx) }\end{array}$ & $\begin{array}{c}\text { WATER } \\
\text { (wt\%) }\end{array}$ & $\begin{array}{c}{ }^{137} \mathrm{Cs} \\
(\mu \mathrm{Ci} / \mathrm{g})\end{array}$ & $\begin{array}{c}{ }^{90} \mathrm{Sr} \\
(\mu \mathrm{Ci} / g)\end{array}$ \\
\hline CORE 34, ID & 0.52 & 0.49 & 1.3 & 45 & 240 & 1300 \\
\hline 2B & 0.43 & 0.30 & 0.8 & 53 & 610 & 4900 \\
\hline $2 \mathrm{C}$ & 0.83 & 0.31 & 0.8 & 58 & 800 & 1100 \\
\hline 2D & 0.75 & 0.40 & 1.1 & 52 & 510 & 2500 \\
\hline COMPOSITE & 0.97 & 0.31 & N.M. ${ }^{2}$ & $38^{3}$ & 750 & 3500 \\
\hline CORE 35, 2D & N.M. & 0.25 & 0.6 & 34 & 700 & 3200 \\
\hline CORE $36,1 \mathrm{C}$ & N.M. & 0.82 & 1.1 & 49 & 410 & 1900 \\
\hline 1D & 0.72 & 0.49 & 1.0 & 58 & 1240 & 15 \\
\hline $2 \mathrm{~A}$ & 0.92 & 0.39 & 0.9 & 57 & 880 & 20 \\
\hline 2B & 0.75 & 0.27 & 0.5 & 41 & 530 & 70 \\
\hline $2 C$ & 0.40 & 0.29 & 0.6 & 64 & 100 & 140 \\
\hline $2 \mathrm{D}$ & 0.56 & 0.23 & 0.5 & 56 & 35 & 200 \\
\hline COMPOSITE & 0.71 & 0.14 & 0.7 & 45 & 800 & 500 \\
\hline
\end{tabular}

'Total cyanide values on a dry wt\% basis; all other analyses on a wet basis.

${ }^{2}$ N.M. = Not Measured; insufficient sample available.

${ }^{3}$ Composite was allowed to air dry in the hot cell which resulted in a low value.

DSC is often used to measure thermal decomposition temperatures, heats of reaction, reaction temperatures, melting points, and solid-solid transition temperatures. TGA is used to measure thermal decomposition temperatures, water content, and reaction temperatures. The two methods usually provide complementary information. TGA and DSC plots are shown in Figures 2-5 and 2-6 for the quarter-segment $36-2 \mathrm{~A}$ sample. 
Figure 2-5. Scanning Thermogravimetric Analysis of 241-C-112 Core 36 Segment 2A.

ํㅗㄹ

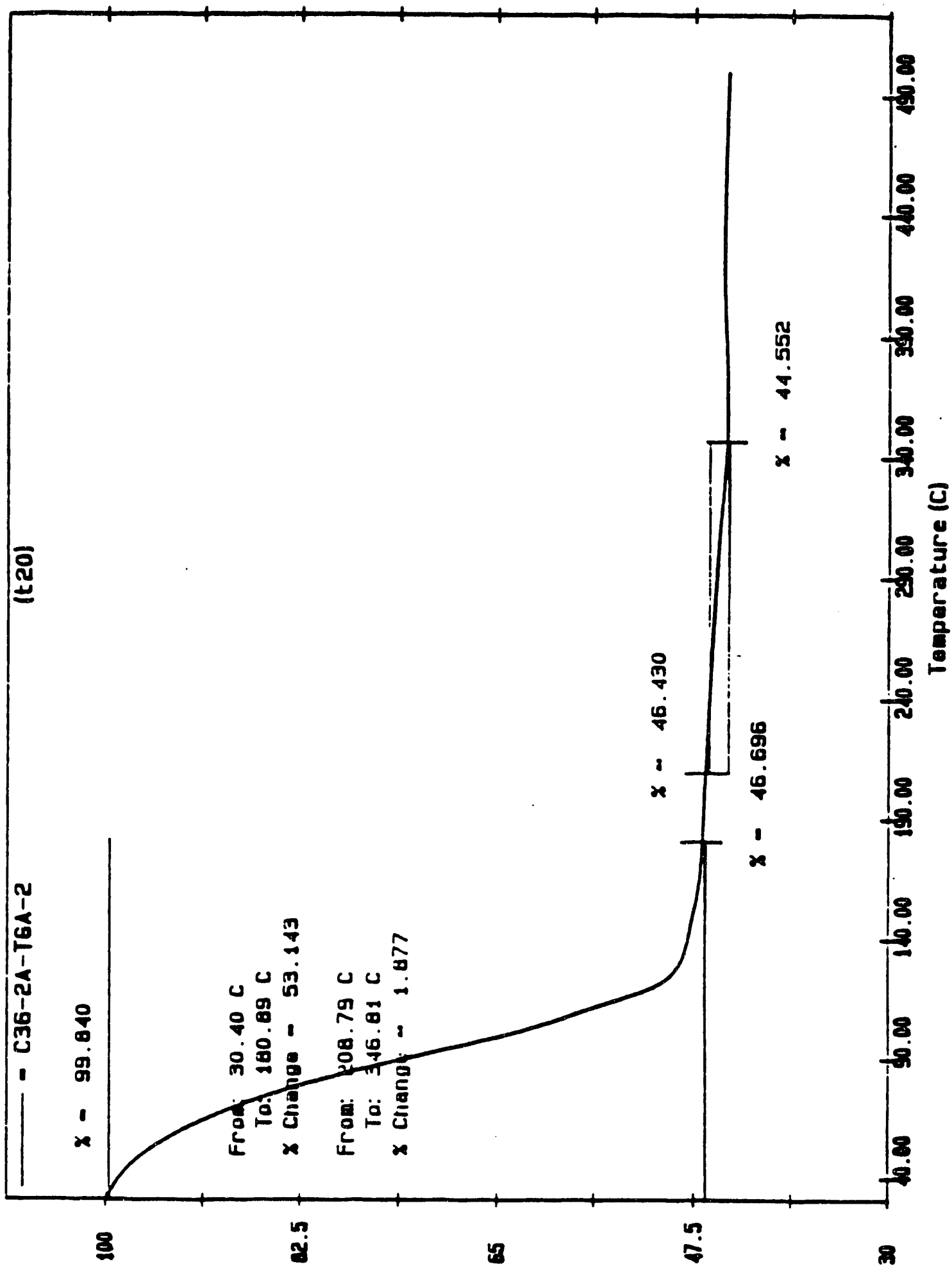

(n) LHOI3M 
Figure 2-6. Differential Scanning Calorimetry of 241-C-112 Core 36 Segment 2A.

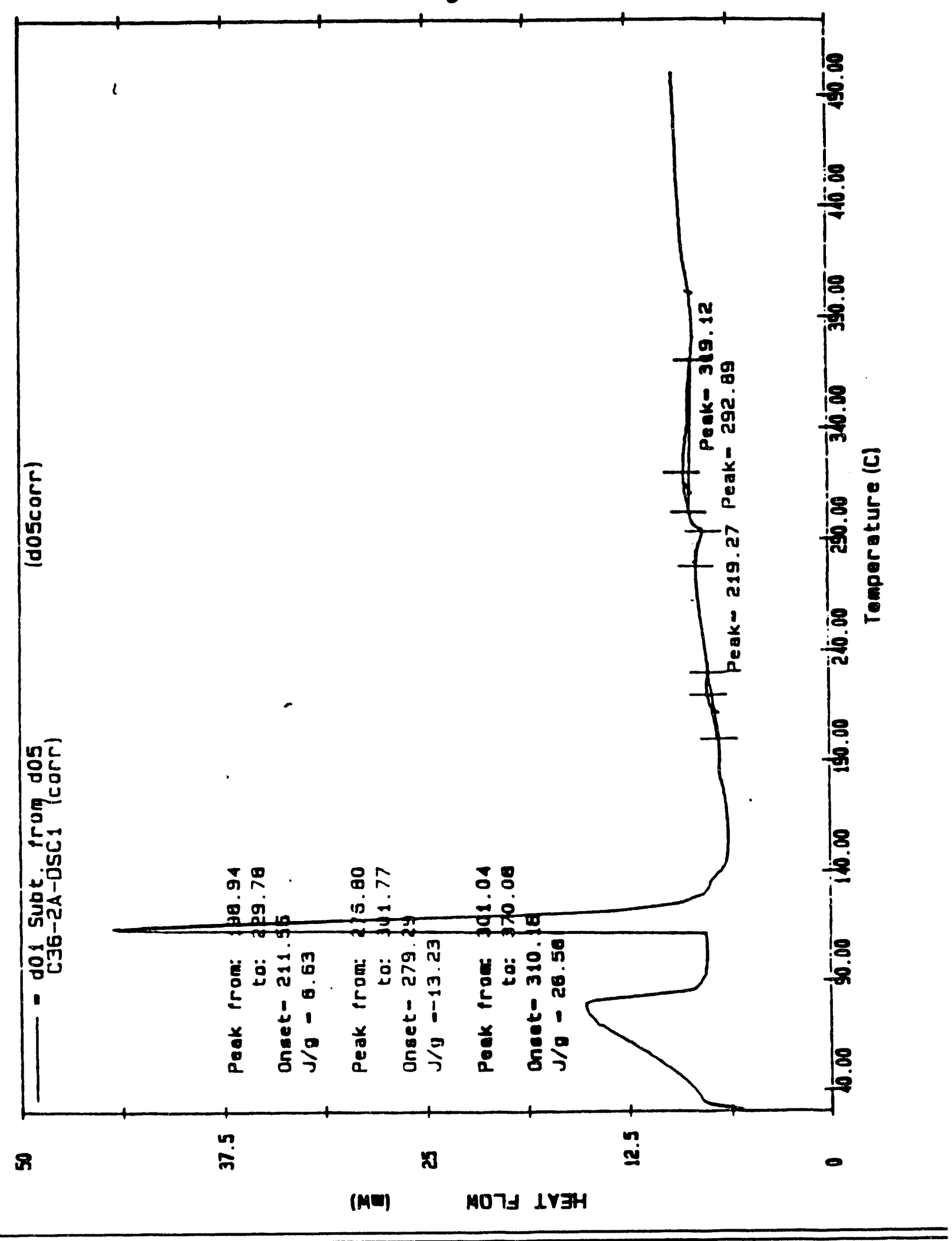


Examination of Figures 2-5 and 2-6 shows that the first transition in each sample is endothermic and begins at the lower temperature limit of the analysis $\left(30^{\circ} \mathrm{C}\right)$ and is essentially complete between $140{ }^{\circ} \mathrm{C}$ and $200{ }^{\circ} \mathrm{C}$. The most likely phenomena occurring in this region is the release of the bulk and interstitial water in the core sample material. The endotherms exhibited in this region are quite substantial (typically, $700-1200 \mathrm{~J} / \mathrm{g}$ ).

Exotherms and additional weight loss are routinely detected between 260 $300{ }^{\circ} \mathrm{C}$ in all the samples. Similar exotherms and weight changes were observed in previous thermal analysis studies of cesium nickel ferrocyanide (Scheele et al. 1991) and other simulant materials (Jeppson and Wong 1993). Dried simulant materials demonstrated much larger exothermic responses than those observed in the tank 241-C-112 waste. However, the magnitude of the exotherms observed correlates roughly with the predicted exotherms derived from the amount of cyanide present in the waste.

Tables 2-2 and 2-3 summarize the heat of reaction for the dry core samples. Note that the highest heat of reaction observed was $-8.6 \mathrm{cal} / \mathrm{g}$ of dry waste. The exotherm shapes and weight changes are similar for both actual and simulant waste, with the heat of reaction per mole of cyanide from tank 241-C-112 waste agreeing well with the values obtained for simulants. The difference in total cyanide accounts for the different heat of reaction values. Propagating reactions are precluded in material with less than $-100 \mathrm{cal} / \mathrm{g}$ heat of reaction. The measured heat of reactions were at least an order of magnitude less than this. Based on analytical results from the two core samples taken from 241-C-112, the waste poses no threat of propagation.

It has been postulated that low cyanide values are the result of aging of the ferrocyanide waste (see Section 2.5.1). The addition of high caustic liquid waste to the ferrocyanide tanks resulted in solubilization of the ferrocyanide. The cyanide was subsequently destroyed by hydrolysis, forming ammonia and sodium formate. Vapor analyses of ferrocyanide tank dome spaces have shown detectable concentrations of ammonia. 
Table 2-2. Heat of Reaction Values of 241-C-112 Core 34.

\begin{tabular}{|c|c|c|c|}
\hline SAMPLE & $\begin{array}{l}\text { TOTAL } \\
\text { CYANIDE } \\
\text { (mX)l }\end{array}$ & $\begin{array}{l}\text { BQUTVALENT } \\
\text { FERROCYANIDE } \\
\text { (WTX) }\end{array}$ & $\begin{array}{c}\text { HEAT OP } \\
\text { REACTION } \\
\text { (cal/g of dry wame) }\end{array}$ \\
\hline 1D & 0.52 & 1.06 & -5.1 \\
\hline $2 B$ & 0.43 & 0.87 & -6.7 \\
\hline $2 C$ & 0.83 & 1.69 & -6.1 \\
\hline $2 D$ & 0.75 & 1.52 & -6.7 \\
\hline COMPOSITE & 0.97 & 1.97 & -4.4 \\
\hline
\end{tabular}

'On a dry wt $\%$ basis.

Tabie 2-3. Heat of Reaction Values of 241-C-112 Core 36.

\begin{tabular}{|c|c|c|c|}
\hline SAMPLE & $\begin{array}{l}\text { TOTAL } \\
\text { CYANIDE } \\
(\operatorname{ar} x)^{1}\end{array}$ & $\begin{array}{l}\text { EQUTVALENT } \\
\text { FERROCYANIDE } \\
\text { (WIX) }\end{array}$ & $\begin{array}{c}\text { HEAT OF } \\
\text { REACTION } \\
\text { (cal/g of dry warte) }\end{array}$ \\
\hline $1 \mathrm{C}$ & N.M. & N.M. & -5.8 \\
\hline $1 D$ & 0.72 & 1.46 & -8.0 \\
\hline $2 \mathrm{~A}$ & 0.92 & 1.87 & -5.2 \\
\hline $2 B$ & 0.75 & 1.52 & -3.7 \\
\hline $2 \mathrm{C}$ & 0.40 & 0.81 & NO EXOTHERM \\
\hline $2 \mathrm{D}$ & 0.56 & 1.14 & NO EXOTHERM \\
\hline COMPOSITE & 0.71 & 1.44 & -8.6 \\
\hline
\end{tabular}

'On a dry wt\% basis.

Three one-segment cores $(47,48$, and 49) were extruded from tank 241-C-109 and analyzed. Poor sample recovery (approximately $35 \%$ ) was obtained for core 48. Preliminary analytical results were received. Cores 47 and 49 were divided into three 4.75 inch quarter-segments and composites. Core 48 contained material from only one and a fraction quarter-segments. The upper quarter-segments of cores 47 and 49 contained $18-21$ wt\% moisture; the middle quarter-segments contained $28-40 \mathrm{wt} \%$ moisture; and the bottom quartersegments contained $39-40 \mathrm{wt} \%$ moisture. None of the core 47 and 49 quartersegments or composites exhibited exotherms during DSC analyses. All contained a moderate to large endotherm in the temperature range where a ferrocyanide 
exotherm peak would be expected. However, the single quarter-segment recovered from core 48 did show a small exotherm of -6.2 to $-6.7 \mathrm{cal} / \mathrm{g}$ between $250-340^{\circ} \mathrm{C}$. The tank 241-C-109 material appears to be no more reactive than tank 241-C-112 waste, even though it contains less moisture.

Three four-segment cores were extruded from tank 241-T-107. The first core sample was secured in November 1992; however, core sampling operations were shut down by Westinghouse Hanford as a result of a DOE-RL audit of the vapor space sampling and core sampling operations. Core sampling resumed in February after responses to the audit findings were accepted. A third foursegment core was taken when it was found that the second core sample had poor recovery. Core sampling was completed on March 15, 1993, and hot cell analyses of the samples was started.

A data interpretation report for the two auger surface samples taken from tank 241-BY-104 was prepared and will be released to the public next quarter. The moisture concentration of the surface crust ranged from 15 to $17 \mathrm{wt} \%$. The crust was not rigid and easily crumbled during auger sampling. Values for the heat of reaction were quite low, as expected, and propagating reactions could not be initiated in the sample. The auger samples were taken from surface saltcake material and were not expected to be highly reactive.

Three $100 \mathrm{~mL}$ supernatant samples were taken from tank 241-T-101 as part of the effort to saltwell pump and stabilize this suspected leaker tank. The samples were taken by the bottle-on-a-string method from the top, middle, and bottom of the one ft thick supernatant layer. No exotherms were seen up to $500{ }^{\circ} \mathrm{C}$ during DSC analysis of the sample. Total organic carbon concentration was 0.7 to $0.9 \mathrm{~g} / \mathrm{L}$; total cyanide ranged from 5.4 to $7.4 \mathrm{ppm}$; $\mathrm{pH}$ ranged from 12.8 to 12.9; and hydroxide $\left(\mathrm{OH}^{-}\right)$concentration ranged between 0.15 to $0.16 \mathrm{M}$. Analytical results from these supernatant samples and the previous review of waste transfer records support the conclusion that the tank contains less than $1000 \mathrm{~g} \mathrm{~mol}$ of ferrocyanide. If ferrocyanide were present, much higher values for total cyanide would be expected (see Section 2.5.1). Therefore, this tank does not belong on the ferrocyanide Watch List.

- Planned Work For Subsequent Months. The data interpretation reports for the tank 241-C-112 core samples and the tank 241-BY-104 surface samples will be completed and issued. The tank 241-C-109 core sample analytical data packages will be reviewed and a data interpretation report initiated. Analysis of the tank 241-T-107 core samples will continue. Push-mode core samples will be taken from tanks 241-C-111 and -108.

Core sampling of ferrocyanide tanks with saltcake will likely be deferred until the rotary-mode core sample truck is available for field use. However, possible 
push-mode core sampling of tank 241-BY-104 will be evaluated. This effort was started because installation of the new thermocouple tree into this tank in September 1992 showed the waste to be softer than expected. Evaluation is scheduled for completion before July 30, 1993, so that push-mode core sampling, if feasible, could still be completed in FY 1993.

- Problem Areas and Actions Taken. Core sample recovery continues to be a problem for push-mode core sampling of tanks. Although the sampler valve was changed to incorporate a spring-loaded mechanism to close the sampler tightly, one of the three tank 241-C-109 core sample segments still had poor recovery. A third core was taken from tank 241-T-107 because one of the first two cores had poor recovery.

It is expected that the majority of the ferrocyanide tanks, particularly those containing a saltcake surface, will require rotary drilling to obtain core samples.

- Milestone Status.

- August 30, 1992: Obtain three full-length push-mode core samples from tank 241-C-109. Core sampling was completed on September 7, 1992.

- September 30, 1992: Obtain two full-length push-mode core samples from tank 241-T-107. One core sample was secured in November 1992; however, core sampling was suspended at that time until findings from a RL audit were satisfactorily resolved. Sampling resumed on February 17, 1993, and was completed on March 15, 1993. A third core sample was taken since one of the original cores showed poor sample recovery.

- March 31, 1993: Complete interpretation of ferrocyanide tank 241-C-112 analytical data and issue a report cleared for public release. This data interpretation report is also addressing another milestone, and the issue date was deferred to April 30, 1993, to accommodate another required review for the document.

- April 30, 1993: Complete interpretation of ferrocyanide tank 241-BY-104 auger surface sample analytical data and issue a report that is cleared for public release. This milestone remains on schedule.

- July 31, 1993: Complete interpretation of ferrocyanide tank 241-C-109 analytical data and issue a report cleared for public release.

- September 30, 1993: Complete interpretation of ferrocyanide tank ?41-T-107 analytical data and issue a report that is cleared for public release. 
- September 30, 1993: Obtain two full-length push-mode core samples from four additional ferrocyanide tanks in FY 1993. The following order for sampling in the tanks is planned: $241-\mathrm{C}-111,-\mathrm{C}-108,-\mathrm{T}-101$, and $-\mathrm{BX}-102$ or $-\mathrm{BX}-106$. If feasible, sampling of tank $241-\mathrm{BY}-104$ may be substituted for one of the last three tanks listed.

- September 30, 1994: Secure core samples from four ferrocyanide tanks (tanks 241-BY-104, -110, -107, and -105).

- September 30, 1995: Obtain core samples from four ferrocyanide tanks (tanks 241-BY-103, -112, -TY-103, and -BY-106).

- September 30, 1996: Obtain core samples from four ferrocyanide tanks (tanks 241-BY-101, -TY-101, -104, and -BY-110).

- September 30, 1997: Obtain core samples from the remaining five ferrocyanide tanks (tanks 241-BX-106, -111, -BY-111, -TX-118, and -BY-108).

\subsubsection{Simulated Ferrocyanide Waste Preparation and Characterization}

Ferrocyanide waste precipitates were and are being prepared and analyzed to determine the composition, physical properties, and chemical reaction properties of simulants that represent ferrocyanide waste stored in SSTs. The analytical results from these simulants, along with analysis of actual tank waste samples, waste tank monitoring, and waste modeling, provide information to characterize, with a great deal of assurance, any safety concerns of the sludge in each of the ferrocyanide tanks. The results will also provide a technical basis for (1) safety measures to be taken; (2) decisions on appropriate actions leading to closure of the ferrocyanide USQ; and (3) eventual remediation of the waste.

Five waste simulants (without radioactive species) are being used to represent the variety of waste produced in the mid-1950s and stored in SSTs. The wastes produced at the Hanford U Plant are represented by $U$ Plant 1 and $U$ Plant 2 test mixtures. The U Plant 1 waste simulant represents 41 of 59 batches; the U Plant 2 simulant represents 9 of 59 batches of U Plant waste. Each U Plant batch was about 2,300,000 L $(600,000 \mathrm{gal})$. The other nine batches of $U$ Plant waste are expected to have a ferrocyanide concentration between that of $U$ Plani 1 and U Plant 2, and a test mixture representing these batches will not be prepared and tested.

The In Farm flowsheet waste (in four C Farm tanks) is represented by In Farm 1 and In Farm 2 test mixtures. The In Farm 1 is representative of one batch (expected to have the greatest ferrocyanide concentration) of the 29 In Farm batches processed in the 1950s. In Farm 2 is representative of 11 intermediate ferrocyanide concentration batches of the 29 
In Farm batches. An average size In Farm batch was approximately 1,500,000 L $(400,000 \mathrm{gal})$. It should also be noted that six of these 29 scavenging batches did not contain any ferrocyanide, but did contain nickel sulfide to enhance precipitation of ${ }^{\circ} \mathrm{Co}$. A T Plant mixture is also being prepared for testing to represent the six $\mathrm{T}$ Plant batches produced.

Three main adjustments from the actual processes used in the 1950s were made in the laboratory scavenging preparation method to provide waste simulants thought to closely represent present sludges. These changes are as follows: (1) the solution concentrations were adjusted to include nitrite at a 1:3 mole ratio of nitrite/nitrate, to account for nitrite buildup over time in the wastes by radiolysis of nitrate; (2) the waste simulants prepared or being prepared for characterization do not or will not contain radioactive isotopes present in actual waste, because of the difficulty in working with radioactive materials; and (3) the settled waste simulants from the laboratory scavenging process were centrifuged at a force of $2,500 \mathrm{~g}$ to mimic an equivalent 30 gravity year settling period.

- Progress During the Reporting Period. Simulant characteristics will be used to help assess safety concerns associated with the ferrocyanide sludges stored in single-shell waste tanks at the Hanford Site. A report on simulant characteristics, Ferrocyanide Waste Simulant Characterization (WHC-EP-0631), was cleared for public release in January 1993 (Jeppson and Wong 1993). Included in the report are simulant preparation procedures, measured physical properties, chemical composition, and thermodynamic properties of four simulants (U Plant 1 and 2, In Farm 1 and 2).

Adiabatic calorimetry and reaction propagation rate tests on the ferrocyanide waste simulants have shown that sustained reactions cannot occur in waste containing more that $12 \mathrm{wt} \%$ unbound water (Jeppson and Wong 1993). In Farm 1 simulant, containing the highest postulated ferrocyanide concentration, could not be ignited or made to sustain a propagating reaction even when subjected to a strong ignition source.

Propagation experiments on dried simulants (approximately $0 \mathrm{wt} \%$ unbound water) showed that greater than $13 \mathrm{wt} \%$ ferrocyanide was required to sustain a propagating reaction. The highest ferrocyanide content in the simulants (In Farm 1) is less than $26 \mathrm{wt} \%$ on a dry basis. Dry U Plant simulants did not exhibit propagating reactions even when heated to $500{ }^{\circ} \mathrm{C}$. However, U Plant simulant did exhibit self heating from 270 to $620^{\circ} \mathrm{C}$.

Dry In Farm simulants exhibited slow propagating reactions $(5$ to $10 \mathrm{~cm} / \mathrm{min}$ ) when externally heated to $245^{\circ} \mathrm{C}$. This is equivalent to a burn, and is much slower than a detonation ( $>300 \mathrm{~m} / \mathrm{s}$ ). Reaction temperatures up to $1150{ }^{\circ} \mathrm{C}$ were measured during these tests, and indicate that possible aerosol releases should be evaluated. 
A literature search was completed and the process used at the Hanford Site to produce the $\mathrm{T}$ Plant ferrocyanide sludge was identified. $\mathrm{T}$ Plant simulant is currently being produced for characterization and reactivity testing. This simulant is expected to have a lower concentration of ferrocyanide than the In Farm simulants, but slightly greater than the U Plant simulants.

Tests to determine the amount of moisture retained by drained simulants are progressing. A free flowing liquid drainage test at one atmosphere pressure has completed about 9 months with loss of about $17 \mathrm{wt} \%$ of the original water. Liquid continues to drain slowly from this material; however, the rate of drainage is decreasing. Free flowing scoping centrifugation tests were conducted at 50,170 , and $1740 \mathrm{~g}$. Results of these tests will be available next quarter. Heating experiments will be conducted on the ferrocyanide simulants by FAI to determine if localized dry out is possible.

- Planned Work for Subsequent Months. T Plant flowsheet waste simulant will be prepared next quarter for characterization and testing. Drainage and dry-out tests will be continued.

- Problem Areas and Actions Taken. None.

- Milestone Status.

- December 31, 1992: Issued draft report on the flowsheet waste simulant compositions and ferrocyanide species characterization for internal review.

- January 29, 1993: Issued final report (WHC-EP-0631) on the flowsheet waste simulant compositions and ferrocyanide species characterization. This report was issued on schedule.

- July 30, 1993: Complete dry-out and moisture drainage tests and issue reports.

\subsubsection{Position Paper on Safety of Ferrocyanide Tanks}

In June 1991 the Tanks Advisory Panel (TAP) requested that Westinghouse Hanford prepare a position paper on the state of knowledge on the ferrocyanide safety issue. The intent of the paper was to document what was known about continued safe storage of the ferrocyanide waste in the high-level waste tanks at the Hanford Site. The primary focus of the report was to assess whether it is possible for a significant exothermic chemical reaction to occur in the tanks under existing conditions and, if possible, whether the reaction could reach a runaway state where radioactive aerosols would be expelled from the tank, as postulated in the General Accounting Office (Peach 1990) report. The safety of continued storage is of 
interest for all long-term storage, mitigation, remediation, or treatment options, because significant storage time would still accrue before options could be selected and completed that would modify the waste form and render it safe.

The ferrocyanide position paper, and subsequent revisions, represents a snapshot in time of (1) what is known about ferrocyanide wastes stored in underground tanks at the Hanford Site; (2) what this information means in terms of storage safety; (3) what key uncertainties exist; and (4) what must be done to resolve the USQ. The position paper is an overview document with technical backup provided by both the ferrocyanide hazards assessment document (Grigsby et al. 1992) or, in the future, by the technical basis document to be prepared to resolve the Ferrocyanide USQ (see Sections 2.4.4 and 2.4.6).

A predecisional position paper (report) was issued November 27, 1991, for DOE and TAP review. Comments were received by May 1992 and the document was revised and cleared for public release as WHC-EP-0531, Rev. 1 (Postma et al. 1992) on July 24, 1992. Updates of the position paper will be issued as significant new information becomes available, and as results of core sample analyses are reported.

- Progress During the Reporting Period. A decision was made this quarter to accelerate the submittal of a safety analysis and a technical basis document supporting the safety analysis for resolution of the Ferrocyanide USQ.

Documentation will be prepared for transmittal to DOE by September 30, 1993. This submittal was originally planned for mid FY 1994, but studies completed to date indicate that an uncontrolled, exothermic reaction in any of the ferrocyanide tanks is a highly unlikely event, given the current conditions of temperature and moisture in the tanks. Further discussion on this subject is found under Section 2.4.5.

An updated position paper on the status of the ferrocyanide safety issue will be prepared early in FY 1994 in time for transmittal to DOE by December 31, 1993.

- Planned Work for Subsequent Months. Work on the updated ferrocyanide position paper will commence during the last quarter of FY 1993.

- Problem Areas and Action Taken. None

- Milestone Status.

- November 27, 1991: Issue position paper on current understanding of ferrocyanide safety issue. This was completed on schedule.

- March 15, 1992: Issue position paper as a document cleared for public release. This was delayed because review comments were not received on 
the requested schedule. Revised date: July 1992. The position paper was released as a public document on July 24, 1992.

- December 31, 1993: Issue a ferrocyanide position document, approved for public release, that updates the current understanding of the ferrocyanide safety issue. This will be a revision of WHC-EP-0531 (Postma et al. 1992).

\subsubsection{Ferrocyanide Waste Tanks Hazards Assessment}

The scope of the ferrocyanide hazards assessment task was to provide a technical assessment (and periodic updates) of the ferrocyanide waste tank safety concerns and progress towards resolution of the USQ. These assessments are based upon information as it becomes available from the Ferrocyanide Safety Program. Contributions are included from FAI, LANL, PNL, Westinghouse Hanford, and other sources.

A predecisional interim report assessing the ferrocyanide waste tank hazards was issued on December 3, 1991, for review and comment by TAP, DOE-HQ, and RL. Comments were incorporated into a new revision, approved for public release, and the document was issued on July 24, 1992 as WHC-SD-WM-RPT-032, Rev. 1 (Grigsby et al. 1992). The report is a review of the understanding of the ferrocyanide hazard, at the time the report was prepared. It presents an integrated evaluation and interpretation of (1) historical data; and (2) recentlyacquired information. These interim reports will continue to be revised and expanded as additional information becomes available through ongoing work.

Several review comments received on the predecisional document could not be resolved in the July 1992 release, because sufficient information was not available at the time the report was written. These comments were to be incorporated into the next revision of the document.

- Progress During the Reporting Period. The effort to update the ferrocyanide hazards assessment document was redirected this quarter towards developing a safety analysis and a technical basis document to close the Ferrocyanide USQ. Since there wo sld be considerable overlap in the contents of the technical basis document and the hazards assessment report, a decision was made to combine the two into a single document. This document will provide the technical basis for closure of tue Ferrocyanide USQ. It will be a companion document to the safety analysis, and both will be submitted to DOE by September 30, 1993.

A key portion of the technical basis document will be devoted to showing that hot spots within the ferrocyanide waste are incredible. A hot spot position paper is now beir.g prepared (Section 2.1.4) for transmittal to DOE by April 15, 1993, that provides the technical basis for this statement. Hot spot temperatures are 
Iimited to the boiling point of the waste liquor $\left(120^{\circ} \mathrm{C}\right)$ because of strong capillary forces which continue to wick moisture towards any hot spot that might be developing. The latent heat of vaporization for waster is also greater than the energy produced by a ferrocyanide reaction. This limits the growth of a hot spot because transfer of heat away from a hot spot is always greater than the rate of heat production.

- Planned Work For Subsequent Months. Work on preparation of the technical basis document will accelerate during the next two quarters. Technical information from all the ferrocyanide safety program tasks will be gathered into the safety analysis and the technical basis document. The planned approach and key safety criteria thiat must be met for closure of the Ferrocyanide USQ (see Section 2.4.5) will be addressed in detail. The technical basis for each safety criterion and how each can be met will be presented in the safety analysis. The objective of the technical data presented will be to show that in situ storage of the waste is safe, and what controls that should be implemented to ensure that safety.

- Problem Areas and Action Taken. The Aerosol Experts Panel that met in March 1992 reviewed available data on the ferrocyanide safety issue and recommended that small-scale aerosol tests be conducted. These tests were originally planned for the second half of FY 1992, but were deferred to FY 1993. Present planning for FY 1993 does not provide for these tests because of resource constraints. Westinghouse Hanford is currently pursuing a reduced aerosol testing program.

To obtain information on aerosol generation, the ferrocyanide waste simulants tested at FAI are being analyzed. The amount of cesium lost during the propagation tests will be determined. The In Farm 1 simulant had cesium added to the flowsheet for this purpose. Additional aerosol sampling tests are also being conducted at FAI (see Section 2.5.2). If considerable cesium was lost during the dry simulant burn tests, and in the new tests being conducted at FAI, then a small-scale aerosol test(s) may be conducted to determine a more accurate source term and particle size distribution than possible with the FAI tests. If less than $10 \%$ of the cesium is lost, then small scale testing may not be warranted.

- Milestone Status.

- May 31, 1993: Complete the first update of the ferrocyanide hazards assessment document (Grigsby et al. 1992) and issue as an approved public report. This milestone has been deferred and combined with the technical basis document supporting a safety analysis to close of the Ferrocyanide USQ. Submittal of the document, approved for public release, is scheduled for September 30, 1993. 
- May 31, 1993: Complete small-scale aerosol tests and complete final aerosol report. This work is currently not authorized in the ferrocyanide program budget approved for FY 1993.

- July 31, 1993: Complete parametric and aerosol tests on the most reactive (In Farm 1) flowsheet simulant at FAI and issue a test report approved for public release.

- September 30, 1993: Complete a final report, approved for public release, on dose consequence recalculations. Included with the report will be an update of progress towards closure of the ferrocyanide USQ. This scope of work will be combined with the safety analysis and the technical basis document to be submitted to DOE on September 30,1993, for closure of the Ferrocyanide USQ. A separate report on this subject will not be issued.

- July 1994: Issue a second update of the ferrocyanide hazards assessment document. This milestone will be deferred or canceled pending disposition of the safety analysis for closure of the Ferrocyanide USQ.

\subsubsection{Closure of the Ferrocyanide Unreviewed Safety Question}

Since inception of the Ferrocyanide Safety Program at Westinghouse Hanford, the ultimate objective of the program has been to resolve the ferrocyanide safety issue and show via safety documentation that storage of the waste in the tank is safe until final disposal in the Hanford Waste Vitrification Plant. To accomplish that goal the USQ must be closed. A new activity was started during the last quarter of FY 1992 to (1) devise a strategy that would be acceptable to DOE and oversight panels; and (2) follow with a detailed USQ closure plan.

The DOE order on USQs establishes the process for USQ identification and closure (DOE 1991). The steps in the USQ process include the following.

- Identify a situation that may be a potential USQ.

- Take action to place the facility in a safe condition while a safety evaluation is prepared, so as to determine if an actual USQ exists.

- If a USQ is identified, establish the interim-operating conditions for safe operation of the facility while a safety analysis is being performed.

- Perform a safety analysis to close the USQ by establishing a new safety envelope relative to the USQ issue. 
- Incorporate into the existing Safety Analysis Report (SAR) or authorization basis any changes that are needed as a result of the safety evaluation, safety analyses, or other actions taken.

The USQ process depends upon an authorization basis that describes those aspects of the facility design basis and operational requirements relied upon by DOE to authorize operation. The authorization basis is described in documents such as the facility SAR and other safety analyses, Hazard Classification Documents, Technical Safety Requirements, DOE-issued safety evaluation reports, and facility-specific commitments (such as the SAs).

The potential hazards of a ferrocyanide-nitrate/nitrite reaction were discovered to represent an inadequacy in the authorization basis. Therefore, an USQ was declared for the ferrocyanide safety issue, and activities in the waste tanks that could increase the likelihood of an accident involving the ferrocyanide-nitrate/nitrite reaction were restricted (Deaton 1990). Until the USQ is closed, proposed intrusive activities that may impact the safety of the ferrocyanide tanks must be assessed for potential safety and environmental consequences. Furthermore, these activities must be authorized by DOE.

Safety Assessments are the documents prepared to provide the technical basis to assess the safety of a proposed activity and to provide proper controls to maintain safety. The SA, along with the accompanying EA, provides the basis for DOE authorization of the proposed activities.

Since inception of the Ferrocyanide Safety Program, safety assessment documents have been completed for vapor space sampling of all 24 tanks, waste surface sampling, push-mode core sampling, TC tree installation in sound and leaker tanks, and removal of pumpable liquid from leaking tanks (also known as interim stabilization). Work on a limited SAR for rotarymode core sampling has started.

- Progress During the Reporting Period. Based on safety analyses to date, a Justification for Continued Operations (JCO) for selected activities in ferrocyanide tanks was prepared and submitted in January 1993 for approval. The following activities are covered in this JCO: vapor sampling or monitoring; small additions of water for special flushes and from intrusion of rainwater and snow melt; non-intrusive activities such as surveillance, LOW scans, instrument calibration and repair, utility installations, and grinding and welding in the vicinity of the tanks; manual surface level monitoring, in-tank photography, installation/removal of instrumentation, HEPA filter testing, and other activities that break tank containment that have already been addressed in safety assessments; waste intrusive operations such as liquid sampling, TC tree installations, LOW installations, saltwell pump installations, push-mode core sampling, and auger sampling; and interim stabilization from the eight ferrocyanide tank that still contain pumpable liquids. Approval of the JCO will allow Westinghouse Hanford to complete the specified activities in accordance 
with established company policies and procedures without having to obtain DOE approval for each operation. This will reduce the cost and schedule associated with getting the operations authorized.

The Ferrocyanide USQ Closure Plan was completed and transmitted to DOE as a predecisional document on January 29, 1993. The approach to be taken and the key safety criteria that must be proven are presented and discussed in the plan. Review of the plan by several oversight panels, including the TAP and the Waste Management External Advisory Committee, was requested by Westinghouse Hanford. Comments will be incorporated and a final plan, approved for public release, will be issued next quarter.

As reported last quarter, the SA and the EA for removal of pumpable liquid (interim stabilization) from ferrocyanide tanks were submitted to DOE on September 30, 1992. Comments were received from DOE and the SA was revised and resubmitted to DOE in January 1993.

A decision was made to revise the existing SA for installing TC trees in sound (non-leaking) ferrocyanide tanks so that installation in leaker tanks was addressed as well. A study to evaluate and identify alternative methods for installation of TC trees in assumed leaker ferrocyanide tanks was completed. The previous method used relatively large volumes of water to sluice the TC tree through the waste. An ultra high pressure concept that uses minimal quantities of water was chosen for final testing and design. Revision of the SA and EA is now $95 \%$ complete; the documents are scheduled for transmittal to DOE in April 1993.

Preparation of a safety assessment for core sampling of ferrocyanide and other Watch List tanks that contain hard waste (e.g., saltcake) has started. This type of sampling will be performed with a rotary drill system. Design and construction of the rotary sampling rig was completed this quarter, and it is being acceptance tested. The rotary drill system is expected to be deployed for field operation in October 1993.

On October 4, 1992, tank 241-T-101 was declared an assumed leaker tank based upon liquid level changes in the tank that had occurred over several months. This is one of eight ferrocyanide tanks that still contains pumpable liquid. Approval of a safety evaluation was completed, and DOE approval to pump tank 241-T-101 was received. Pumping of 241-T-101 began March 12.

- Planned Work for Subsequent Months.

A technical basis report documenting a safety analysis for closure of the USQ will be prepared; a schedule will not be set until the USQ closure plan is accepted and released. 
The revised SA and new EA for installation of TC trees in the assumed leaker ferrocyanide tanks will be completed and submitted to DOE in April.

- Problem Areas and Action Taken. None

- Milestone Status.

- October 19, 1992: Submit draft strategy letter to DOE on the proposed approach for resolution of the ferrocyanide USQ. The letter was transmitted to DOE on October 28, 1992.

- October 31, 1992: Issue SA and EA documentation to DOE for rotarymode core sampling of ferrocyanide tanks. Work is nearly complete on the SA and EA documentation, but was stopped when equipment design changes were required. The scheduled date for submittal of the SA and EA is May 7, 1993.

- January 29, 1993: Submitted predecisional USQ closure plan to DOE providing details on the proposed approach for closure the Ferrocyanide USQ. This milestone was completed on schedule.

- February 1, 1993: Received authorization from DOE, based upon revised SA and EA documentation, to proceed with pumping of ferrocyanide tank 241-T-101. This milestone was deferred to February 26, 1993, because the revised $\delta A$ assessment was not transmitted to DOE until January 29, 1993. Authorization to pump 241-T-101 was received from DOE in early March, and pumping commenced on March 12.

- March 30, 1993: Submit SA and EA documentation for installation of TC trees in assumed leaker ferrocyanide tanks to DOE for review and comment. The SA and EA are expected to be issued to DOE by April 16, 1993 (see also Section 2.1.1).

- September 1, 1993: Receive authorization from DOE, based upon revised $\mathrm{SA}$ and EA documentation, to install remaining TC trees in assumed leaker ferrocyanide tanks.

\subsubsection{Concepts for Resolution of the Ferrocyanide Safety Issue}

A predecisional report on three approaches evaluated for resolution of the ferrocyanide safety issue was issued by Westinghouse Hanford in November 1991. The concepts were evaluated 
by selected working groups, as requested by DOE-HQ, as an action item from the June 1991 TAP meeting.

The conclusions supported by this evaluation at the time were as follows:

- The In Situ Safe Storage Option should be continued on a tank by tank basis until the ferrocyanide USQ is satisfied or waste mitigation or remediation can be implemented, if necessary.

- Remediation should be implemented, if needed, on a tank by tank basis when sufficient characterization is completed and an acceptable remediation process is ready for implementation.

- Mitigation approaches, if necessary, should be considered on a tank by tank basis where characterization is complete without closure of the USQ, and only if a remediation process is not ready for implementation.

- Comments were received on the predecisional report from TAP, DOE-HQ, and RL in May 1992. Work on this task since then was directed to revising the report to reflect the latest information available on the ferrocyanide safety issue. Based upon this information, Westinghouse Hanford has taken the position that in situ safe storage is the safe and viable choice for all 24 tanks on the ferrocyanide Watch List.

- Mitigation approaches are not recommended as a separate undertaking, because the condition of the ferrocyanide waste in the tanks poses no imminent threat to the safety of workers and the public or the environment. Mitigation is not required based upon the current understanding of the ferrocyanide safety issue (Cash et al. 1992a; Cash and Dukelow 1992).

- The ferrocyanide safe storage report will also recommend that remediation approaches be considered as part of the pretreatment studies underway in the Westinghouse Hanford Tank Waste Remediation System for single-shell tank waste retrieval and final disposal. Thus, engineering studies to provide specific technical details for design, development, and implementation, as recommended in the predecisional report, will not be conducted on selected mitigation and remediation options. Instead, studies are focusing on in situ safe storage of the ferrocyanide waste.

- Progress During the Reporting Period. Final inputs to the ferrocyanide safe storage report were to have been submitted by February 1993. Only one author responded this quarter, and further work remains to be completed on the document before it is ready for final editing. The remaining authors have promised their inputs by April 30, 1993. 
- Planned Work for Subsequent Months. The document will be submitted for clearance and released for public availability during the next quarter.

- Problem Areas and Action Taken. Final preparation of the report was delayed this quarter because not all of the authors have completed their revisions of the document. The scope of the document was changed to incorporate the latest knowledge on the ferrocyanide safety issue and reflect the selection of in situ safe storage as the defensible option of choice. The authors now expect to complete their input by April 30, 1993, so the report can undergo final editing and clearance.

- Milestone Status.

- November 30, 1992: Issue a report, approved for public release, on selected concepts and recommendations for resolution of the ferrocyanide safety issue. This milestone was delayed to May 28, 1993.

\subsection{DEFENSE NUCLEAR FACILITIES SAFETY BOARD RECOMMENDATION 90-7.5 (CHEMICAL REACTION STUDIES)}

"The schedule for the program on study of the chemical properties and explosive behavior of the waste in these tanks is indefinite and does not reflect the urgent need for a comprehensive and definitive assessment of the probability of a violent chemical reaction. The study should be extended to other metallic compounds of ferrocyanide that are known or believed to be present in the tanks, so that conclusions can be generalized as to the range of temperature and other properties needed for a rapid chemical reaction with sodium nitrate."

Chemical reaction studies on ferrocyanide waste simulants are being conducted by Westinghouse Hanford, PNL, LANL, Washington State University, and FAI. Westinghouse Hanford and PNL have produced flowsheet simulant materials for testing and characterization. PNL is also administering the subcontract with LANL. In FY 1992, LANL completed chemical reaction sensitivity tests on ferrocyanide waste simulants to identify what stimuli (emphasizing non-thermal) may cause a reaction to occur. FAI is conducting adiabatic calorimetry and propagation tests on these same replicated flowsheet materials. The FAI scope of work in FY 1993 was expanded to include selected aerosol studies. 


\subsubsection{Chemical Reaction Studies at Pacific Northwest Laboratory}

Chemical reaction studies are continuing at PNL using flowsheet simulant materials. Waste studies addressing DNFSB Recommendation 90-7.5 were conducted to determine (1) the speciation of cyanides found in the actual tank waste; (2) effects of solid diluents, water, additional fuel sources, and possible catalysts on waste reactivity; (3) the aging effects of $35+$ years of storage in the tanks; and (4) possible microconvection mechanisms which may have allowed mixing of the ferrocyanide sludge with caustic solutions added to the tanks at a later time.

PNL is also administering the subcontract with LANL. In FY 1992 LANL completed chemical reaction sensitivity tests on ferrocyanide waste simulants to identify what stimuli (emphasizing non-thermal) may cause a reaction to occur.

- Progress During Reporting Period.

Cyanide Speciation. The Ferrocyanide Safety Project, Task 3.5 Cyanide Species Analytical Methods Development: FY 1992 Annual Report (PNL-8399) was published and distributed during the quarter. In December 1992, PNL task leaders and project staff met with Westinghouse Hanford program personnel and scientists to develop a ferrocyanide waste sample analysis matrix diagram. Figure 2-7 shows a breakdown of potential sample cyanide analysis requirements identified by this activity. The diagram details the disposition of a typical ferrocyanide tank sample for a maximum cyanide analytical effort. It is anticipated that not all samples will be subjected to all analyses indicated. 
Figure 2-7. Ferrocyanide Tank Sample Analysis Flow Diagram.

\section{Ferrocyanide Waste Analysis Matrix}

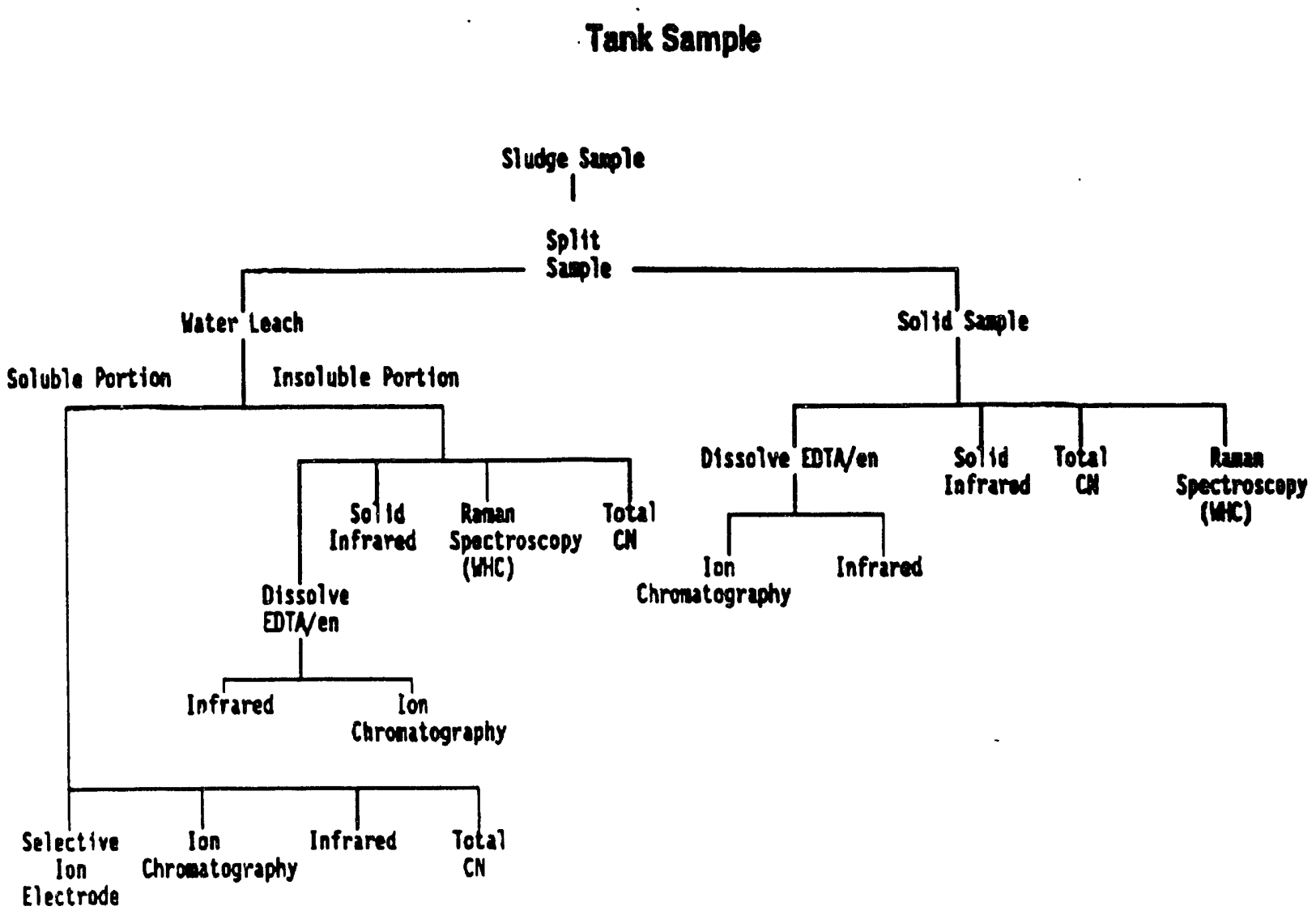


A Fourier transform infrared (FTIR) spectrometer and remote detector were received and installed during the quarter. The remote detector will allow analysis of ferrocyanide samples in a hot hood environment. The detector will be tested using simulated waste materials prior to being installed in a radioactive hood. Acceptance testing of this instrumentation includes the analysis of ferrocyanide and cyanide solutions using various sample cell configurations. These tests will be used to determine the detection limits for the cyanide species of interest. The configurations and techniques employed are similar to those planned to be used on actual ferrocyanide waste samples.

Ferrocyanide simulant (In Farm 2) was analyzed using the FTIR sample cell configuration and by microdistillation. A portion of the simulant was dissolved in a solution consisting of 5 grams of ethylenediamine and 5 grams of ethylenediaminetetraacetic acid diluted to $100 \mathrm{ml}$ with water. Aliquots of the solution were analyzed by FTIR using the independently prepared standards. Ferrocyanide $\left[\mathrm{Fe}(\mathrm{CN})_{6}^{4-}\right]$ was the only cyanide species found. Based on FTIR analysis, the total cyanide content of the simulant was found to be $6.09 \mathrm{wt} \%$.

As an independent check on the accuracy of the FTIR procedure for cyanide species analysis, aliquots of the same dissolved simulant solution were analyzed for total cyanide content by the microdistillation/argentometric titration method (procedure PNL-ALO-285) that is currently under development in a separate task. Microdistillation analysis of the solution indicated that the simulant contained $6.10 \pm 0.05 \mathrm{wt} \%$ cyanide. Spike recoveries were $93-99 \%$. Recoveries of cyanide control samples (spikes of ferrocyanide added to blanks) were $98-100 \%$. Chemical blanks measured approximately $10 \mu \mathrm{g} \mathrm{CN}(n=5)$.

Based on the above results, it can be concluded that (1) the microdistillation total cyanide analysis yields reproducible results; (2) microdistillation blanks are negligible compared to $\mathrm{CN}^{-}$content of samples, as long as the sample taken has $\geq 0.5 \mathrm{mg} \mathrm{CN}$; and (3) the agreement between FTIR and microdistillation results for total cyanide is excellent.

Dissolved ferrocyanide waste and waste simulants contain an array of chemical species that may interfere with solution methods for the quantitative determination of cyanide complexes. In order to assess the impact of suspected chemical species that might interfere with analyses for cyanide containing species, cyanide complexes of concern were systematically measured in the presence and absence of these potential chemical interferants.

The results of these experiments show that the presence of the potential interfering species will not change the measured concentration of ferrocyanide to any appreciable degree. The measured concentration of the ferrocyanide in each solution containing a potential interferant was within $5 \%$ of the standard solution, 
except for the solution containing sodium aluminate, which was approximately $6 \%$ above the standard value. These results are promising considering that the concentration of ferrocyanide was on the low extreme expected to be encountered (0.0106\% as $\mathrm{CN}$ in each solution), and the potential interfering species was at the highest value expected in any of the samples to be analyzed.

This series of experiments also indicated that there was no oxidation of the ferrocyanide to form ferricyanide. The ferricyanide product (or any other cyano complex) was not observed by IR measurements. This was confirmed by the excellent agreement in mass balance measurements as indicated in Figure 2-8. There was also no evidence that any of the potential interferants reacted with the solution cell or attenuated total reflectance (ATR) element. It is critical for the solution cell and ATR element to be inert toward the solutions and species expected to be present within ferrocyanide waste samples.

Figure 2-8. Relative Concentration of Ferrocyanide in Solutions Containing Potential Interferants Compared to Ferrocyanide Measured in Standard Solution.

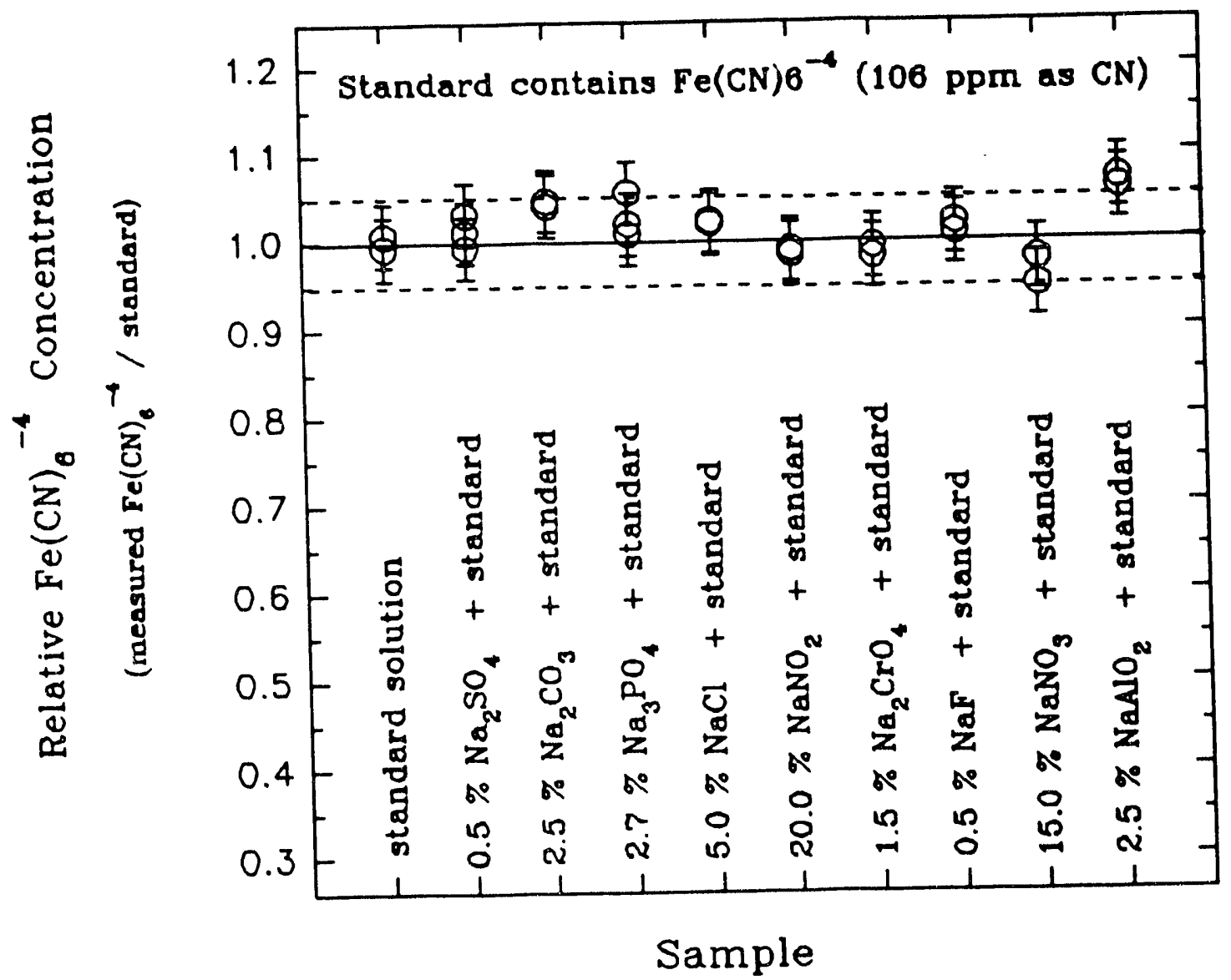


Diluent Screening and Scoping Studies. A draft report on PNL's catalyst, diluent, and initiator studies conducted in FY 1992 was submitted to Westinghouse Hanford for review. Comments were provided and the report is currently in final preparation.

Included in the report are results of studies to determine the effects of oxidant to ferrocyanide ratio, sodium aluminate concentration, and nickel sulfide concentration on the reactivity of ferrocyanide and nitrate/nitrite mixtures. The report also includes the results of a statistically based study to determine the catalytic/initiator effects of EDTA, as well as nickel, chromium, and iron hydroxides.

Aging Studies. A series of dissolution experiments were completed this quarter with vendor-prepared sodium nickel ferrocyanide material. Dissolution trials were conducted with solutions similar to those added to the ferrocyanide tanks (e.g., salts containing phosphate, carbonate, sulfate, nitrate, nitrite, and hydroxide). The results of these experiments are presented in Figure 2-9.

Figure 2-9. Comparison of the Dissolution of Sodium Nickel Ferrocyanide in Caustic Solutions Containing Sodium Phosphate and Sodium Nitrate.

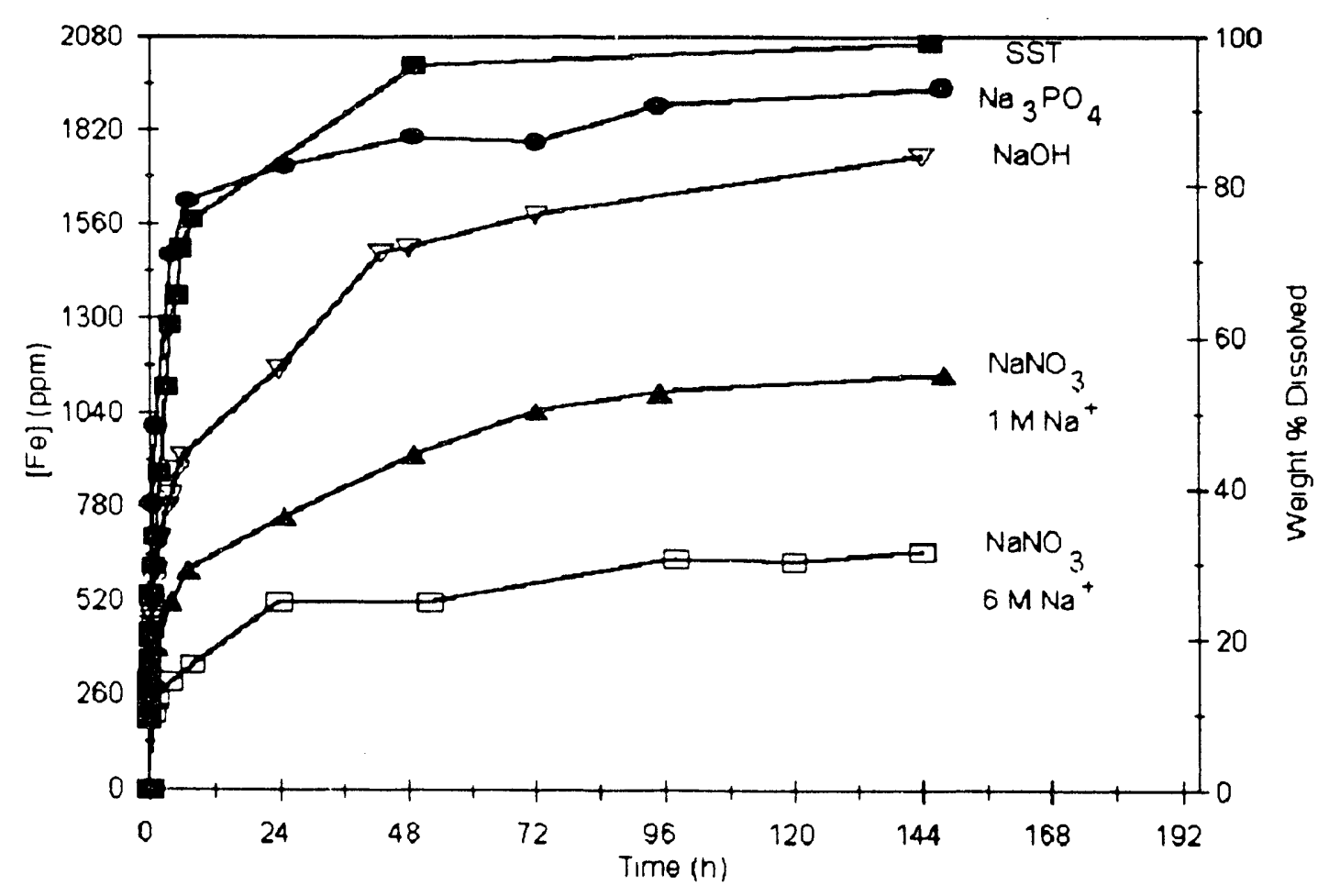


When the $\mathrm{pH} 13$ solution contains $1 M$ or $6 M$ sodium nitrate, dissolution rates are depressed. Higher sodium concentration results in slower dissolution rates, suggesting a common ion effect. This is consistent with dissolution of the vendor-prepared material in the presence of $1 M$ sodium sulfate. The rate was slightly faster than with $1 M$ sodium nitrate. The activity of sodium is expected to be lower with divalent and trivalent anions for which ion-pairing will occur to a greater extent.

Microconvection Modeling. Microconvection modeling studies are being conducted to determine if mechanisms are possible for caustic chemical liquids, which were stored on top of ferrocyanide tank sludges, to mix with the ferrocyanide wastes. If such "convection cell" mechanisms are possible, the high caustic liquids would solubilize the sodium and/or cesium nickel ferrocyanide by conversion to water soluble ferrocyanide. The dissolved cyanide complex might then be destroyed by hydrolysis or be removed from the tank during subsequent liquid transfer operations.

Solubilization and transport of the ferrocyanide would have two effects. First, it would reduce the fuel concentration in the sludge. Second, in the event of art exotherm, the dose consequences of a runaway reaction would be reduced because the amount of cesium available for dispersion would be smaller. Such a phenomenon could account for the lower than anticipated levels of ferrocyanide determined in tank samples analyzed to date.

Westinghouse Hanford and PNL staff consulted with Professors Tom Pigford and Paul Chambré at the University of California-Berkeley to obtain their opinion on the physics of sodium hydroxide diffusion into the layered beds of sodium nickel ferrocyanide in SSTs at Hanford. Pigford and Chambré have lectured and published extensively on nuclear waste disposal, and serve on many oversight committees and advisory panels including the National Academy of Sciences' Nuclear Waste Technical Review Board.

Aqueous diffusion calculations, assuming 1-D geometry in a semi-infinite porous medium and a diffusion coefficient of $10^{-6} \mathrm{~cm}^{2} / \mathrm{s}$, indicate that the mean penetration depth is only about $21 \mathrm{~cm}(8.5 \mathrm{in})$ over a $15 \mathrm{yr}$ period when the tanks were being actively used. Molecular diffusion would be too slow to have had any significant effect in solubilizing the ferrocyanide. The professors made a key point that, under a certain set of conditions, there might exist some sort of "convection cell" that would increase the effective diffusivity of the sodium hydroxide. Plausible mechanisms suggested that could increase the penetration 
rate of sodium hydroxide by an order of magnitude or more included the following:

- Density gradients of the interstitial liquid in the saltcake

- Temperature gradients

- Gas formation and bubble motion

- Density changes as a result of nickel hydroxide precipitation.

The key issue is to determine under what range of conditions these cells would be predicted to exist and whether the waste conditions that existed in the tanks were consistent with these determinations.

A preliminary literature search was conducted to identify previous experimental and modeling studies related to fluid stability in porous media. Several papers were found in which the stability of salt solutions or miscible organic dyes overlying a "sand" saturated with deionized water were investigated. The stability of these systems was related to a modified Rayleigh number that depends on the difference in density $(\Delta \rho)$ and viscosity of fluids, the permeability of the porous medium, and the aspect ratio of the container holding the fluids. When a critical $\Delta \rho$ is exceeded, the system was shown, both theoretically and experimentally, to become unstable, thereby inducing convective mixing of the fluids. The rate of penetration of the higher density fluid was found to be nearly linear $\left(\propto t^{0.85}\right)$, which is much faster than the $t^{0.5}$ rate dependence expected from diffusion alone.

Based on the literature search, a linear stability analysis was performed for a dense fluid layer overlying a porous medium saturated by a less dense fluid simulating postulated tank conditions. It was assumed that both layers are semi-infinite in the vertical direction and of infinite extent in the horizontal direction. This configuration was found to be unconditionally unstable, independent of the properties of the porous medium or the magnitude of the fluid density difference. A porosity equal to $30 \%$ and permeability of 2 darcies was used for the calculations. The analysis shows that the system is unstable if the saltcake has a non-zero permeability. Therefore, finger-like convection is predicted to always occur. The least stable mode was found to have a wave length much smaller than the tank diameter, thereby increasing the total mixing interface area by orders of magnitude. Using water-like properties for the fluids, an assumption that yields the highest penetration, the instability requires a couple of hours to double in amplitude.

This suggests that the contents of a ferrocyanide waste tank containing caustic chemical liquids on top of ferrocyanide tank sludge would be well mixed since 
the tank has a history on the order of years. Follow-up calculations are planned using more realistic properties for the fluids and finite-domain boundary conditions.

- Planned Work For Subsequent Months.

- Continue the aging study dissolution experiments using sodium nickel ferrocyanide and Westinghouse Hanford prepared ferrocyanide flowsheet simulant (In Farm 1A, Rev 4) in single shell tank simulant salts at current and previous tank temperatures and in the presence of an ionizing radiation field.

- Preparations are underway to begin dissolution studies and gamma pit experiments using ferrocyanide flowsheet simulant material. A sample of the simulant In Farm 1A, Rev. 4 will be dried at $60^{\circ} \mathrm{C}$ under vacuum. The dried material will be analyzed for iron, sodium, and cesium before dissolution experiments are conducted. Teflon* liners were procured and will be tested for degradation in the gamma pit. The Teflon liners may not be necessary for the gamma pit experiments, but they will be used if no interfering degradation is observed in order to more closely mimic previous reaction conditions.

- Continue work on cyanide speciation analytical methods including IC methods and solution IR methods. Determine probable interferences that may be encountered in developing analytical methods for actual waste samples. Work will also continue on solids speciation methods using IR and Raman techniques. These methods will be explored further using flowsheet materials.

- Complete a final report on catalyst, initiator, and diluent screening tests conducted in FY 1992.

- Assemble information that contains key physical and chemical properties of waste in the ferrocyanide tanks for use in microconvection modeling studies. Perform follow-on calculations for microconvection models using more realistic properties for the fluids and finite-domain boundary conditions.

- Problem Areas and Action Taken. None

*Registered trademark of E I duPont Co. 
- Milestone Status.

- November 27, 1992: Transmit a final, cleared report on FY 1992 Aging Studies to DOE. The report (Lilga et al. 1992) was issued on November 25, 1992.

- January 22, 1993: Transmit a draft report on FY 1992 PNL catalyst, initiator, and diluent screening studies to Westinghouse Hanford for review and clearance. The draft report was submitted to Westinghouse Hanford on January 22 for review.

- April 30, 1993: Issue a final PNL report on catalyst, initiator, and diluent studies that is approved for public release.

- June 30, 1993: Issue the final, cleared report on small-scale sensitivity tests of ferrocyanide flowsheet simulants conducted by LANL.

- September 20, 1993: Issue a final PNL report of FY 1993 ferrocyanide microconvection modeling activities at PNL; approve for public release.

- September 30, 1993: Issue a final cleared PNL report on the results of aging studies on ferrocyanide waste to Westinghouse Hanford for transmittal to DOE.

- September 20, 1993: Issue a final PNL report, approved for public release, on ferrocyanide speciation method development and deployment of a system in PNL hot cells or laboratory hoods.

\subsubsection{Ferrocyanide Propagation Studies}

Propagation and scoping aerosol tests are being conducted at FAI under contract to Westinghouse Hanford. The results of these tests are used to determine if Hanford Site ferrocyanide waste will ignite, burn, and propagate to involve additional waste from an ignition point. The release of radioactive species under postulated accident conditions is also being determined.

Tests were conducted with dried simulant to evaluate safety concerns associated with postulated hot spot conditions. Propagation velocity is a key parameter in determining safety consequences of postulated burns, including a potential release of radioactivity from confinement. Since the composition of the waste in the storage tanks varies, and is not well known, ranges of material compositions were tested. Present work is focused on the most concentrated ferrocyanide simulant (In Farm 1). 
The present concentration of ferrocyanide in the sludge is in question since ferrocyanide was shown to hydrolyze in the presence of high $\mathrm{pH}$ waste, and possible concentrating mechanisms during the last 40 years have not been ruled out. Initial sample results of $C$ Farm tank waste indicate that the waste ferrocyanide concentrations are considerably lower than the In Farm simulants being tested.

- Progress During Reporting Period. Scoping aerosol and parametric pressure propagation tests were conducted on dried In Farm ferrocyanide simulant this quarter. Propagation rates were determined as a function of initial pressure for the dried In Farm 1 bottom fraction simulant. Cesium release measurements were made for reaction tests conducted with dried (under vacuum at $60{ }^{\circ} \mathrm{C}$ for 24 hours with 1 wt\% water added back after drying) ferrocyanide simulant. These tests indicate that a significant amount of cesium is released during the reaction.

For a test with an initial material temperature of $60^{\circ} \mathrm{C}$ and an initial pressure of 3 atmospheres absolute, the aerosol sample collected contained $21 \%$ of its initial cesium content on a per unit mass basis. For a test with an initial material temperature of $120^{\circ} \mathrm{C}$ and an initial pressure of 3 atmospheres absolute, the aerosol sample collected contained $28 \%$ of its initial cesium content per unit mass. The fraction of total aerosol collected in each test is expected to be about the same ani will be determined by further evaluations. Quantities of sodium, iron, nickel, phosphorous, and strontium were also found in the aerosol samples.

Propagation rates of the parametric initial pressure tests completed to date are shown in Table 2-4 and Figure 2-10. The three tests conducted at an initial temperature of $60{ }^{\circ} \mathrm{C}$ indicate that the propagation rate is very dependent upon initial pressure over the range from 3 to 53 atmospheres. However, for the pressure range ( 1 to 3 atmospheres absolute) applicable to the underground storage tank waste, the propagation rate changes only slightly $(12$ to $13 \mathrm{~cm} / \mathrm{min}$ by extrapolation in Figure 2-10). The propagation test conducted with an initial $120{ }^{\circ} \mathrm{C}$ temperature indicates a greater propagation rate than may be inferred from the lower initial temperature tests. This suggests that there was a lower initial water content in the $120^{\circ} \mathrm{C}$ test material because of heating to the higher initial temperature. Drying tests are currently being conducted to determine the amount of moisture remaining in the simulants when (1) dried under vacuum at $60{ }^{\circ} \mathrm{C}$ for 24 hours; (2) dried at $120^{\circ} \mathrm{C}$ for 18 hours; and (3) dried at $105^{\circ} \mathrm{C}$ for 24 hours.

The two aerosol/propagation tests were conducted in a confinement test chamber (Figure 2-11). About $50 \mathrm{~g}$ of dried (vacuum dried with $1 \mathrm{wt} \%$ water added back after drying) In Farm 1, bottom fraction simulant was loaded and ignited 
Figure 2-10. Propagation Rates for Dried In Farm 1 Simulant as a Function of Pressure and Initial Temperature.

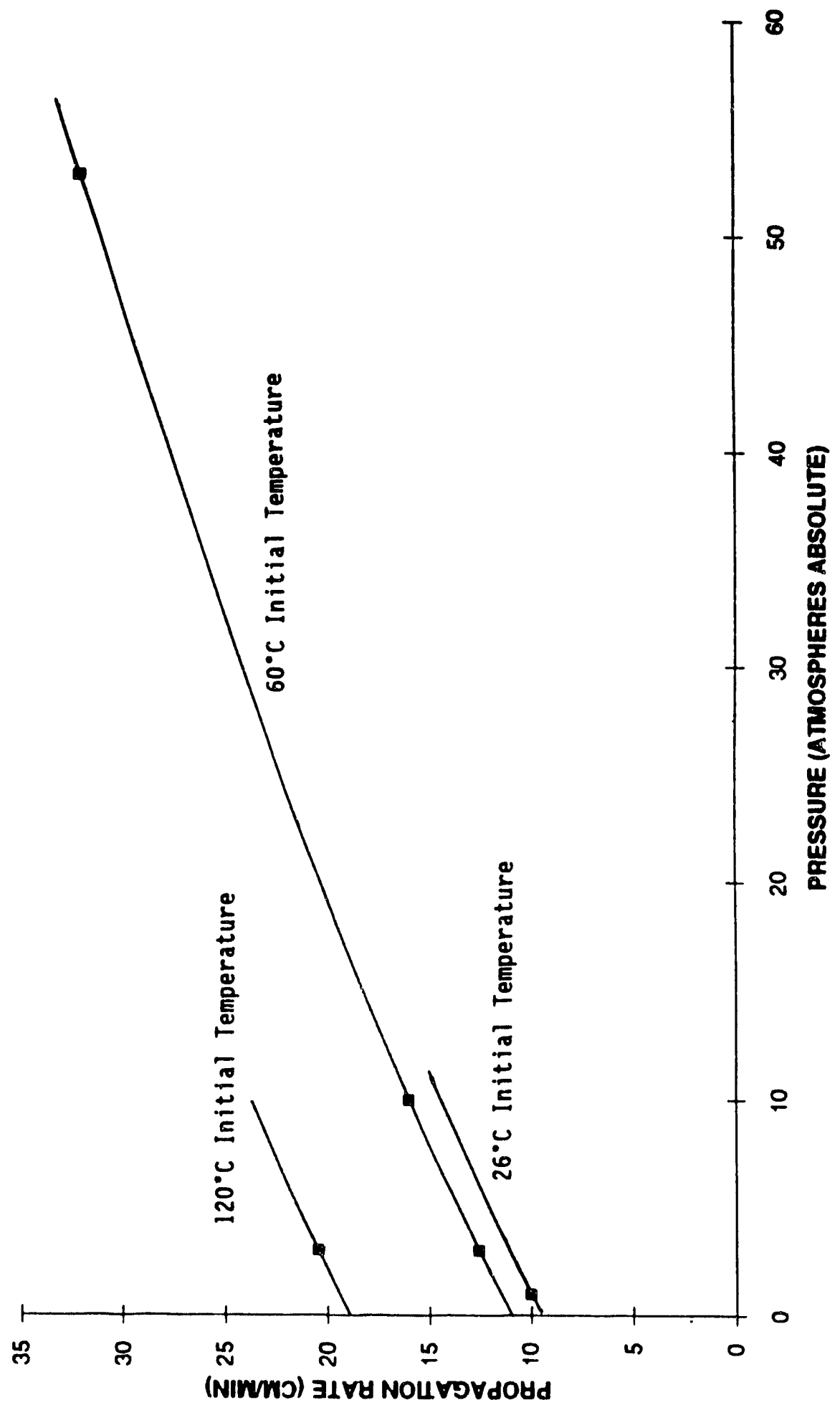


Table 2-4. Comparison of Parametric Pressure-Related Propagation Rates.

\begin{tabular}{|c|c|c|c|}
\hline $\begin{array}{c}\text { Initial Absolute } \\
\text { Pressure } \\
\text { (atmospheres) }\end{array}$ & $\begin{array}{c}\text { Initial } \\
\text { Temperature } \\
\left({ }^{\circ} \mathrm{C}\right)\end{array}$ & $\begin{array}{c}\text { Specific } \\
\text { Gravity }\end{array}$ & $\begin{array}{c}\text { Propagation } \\
\text { Rate cm/min }\end{array}$ \\
\hline 1.0 & 26 & 1.23 & 10 \\
\hline 3.0 & 60 & 1.32 & 13 \\
\hline 10.1 & 60 & 1.26 & 16 \\
\hline 51.7 & 60 & 1.33 & 32 \\
\hline 3.0 & 120 & 1.31 & 20 \\
\hline
\end{tabular}

with a barium peroxide and aluminum powder mixture. Sufficient water is expected to be present in the dried simulant to permit possible conversion of all cesium to cesium hydroxide during the reaction. Cesium hydroxide has a relatively low boiling point $\left(1050^{\circ} \mathrm{C}\right)$ and a high vapor pressure. Cesium is considered to be the radioactive species that could have the greatest dose consequence in the event of a postulated reaction.

The amount of material collected from the aerosol samples is shown in Table 2-5. The ratios of the mass collected for the $120^{\circ} \mathrm{C}$ test to the $60{ }^{\circ} \mathrm{C}$ test are also listed. The mass of aerosol collected for the $60^{\circ} \mathrm{C}$ test was $366.2 \mathrm{mg}$ and for the $120^{\circ} \mathrm{C}$ test was $595.7 \mathrm{mg}$, for a mass ratio of 1.63 . The mass fractions of cesium collected in the aerosol samples indicate that cesium species are considerably more volatile than the nickel or iron species.

Quantities of various gases generated during the In Farm 1 bottom fraction material tests conducted at 10.1 and 51.7 atmospheres absolute pressure were determined and are listed in Table 2-6. The results, shown in moles of gas per mole of ferrocyanide in the simulant, indicate that near theoretical amounts of nitrogen are released but only about one third of the theoretical carbon dioxide is released. This indicates that some metal carbonates are formed, thus minimizing the amount of carbon dioxide released.

Some nitric oxide was formed during the lower pressure test and may come from the decomposition of nitrate/nitrite or as a reaction product. A small amount of hydrogen release was observed in the higher pressure test and may result from the decomposition of sodium hydroxide. Chemical analyses of the solid reaction products are being made to provide information necessary to determine the reaction mechanisms. 
Figure 2-11. Confinement Test Chamber For Propagation and Aerosol Tests.

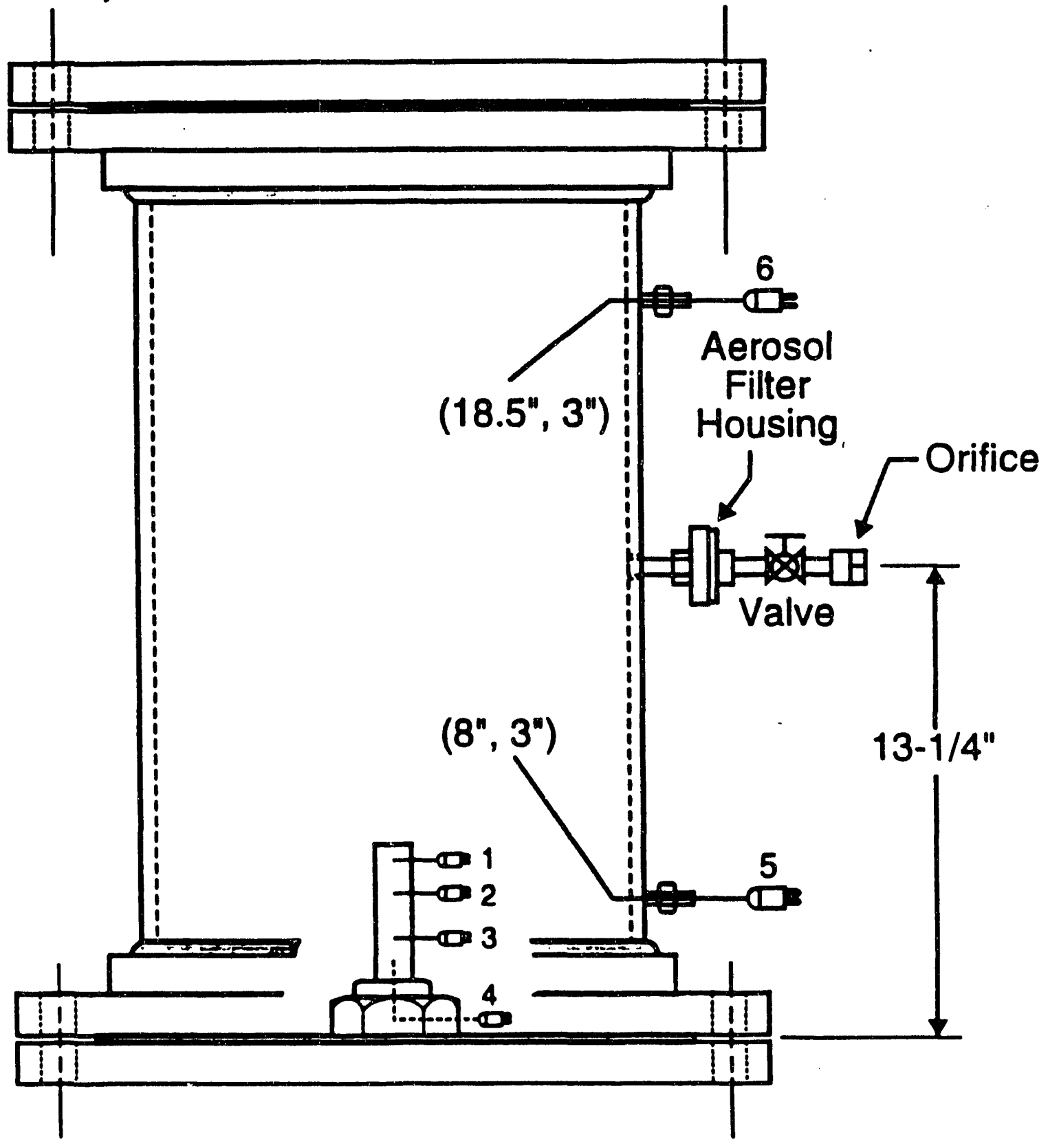

MGQ31041.COR 
Table 2-5. Material Collected from Aerosol Samples.

\begin{tabular}{|l|r|r|r|}
\hline \multirow{2}{*}{ Element } & $60^{\circ} \mathrm{C}$ Test & $120^{\circ} \mathrm{C}$ Test & Mass Ratio $120^{\circ} \mathrm{C}$ \\
\cline { 2 - 3 } & mass $\mu \mathrm{g}$ & mass $\mu \mathrm{g}$ & \multicolumn{1}{|c|}{${ }^{\circ} \mathrm{C}$ Test } \\
\hline $\mathrm{Al}$ & 4,761 & 7,148 & NA \\
\hline $\mathrm{Ba}$ & 1,025 & 834 & NA \\
\hline $\mathrm{Ca}$ & 366 & 322 & NA \\
\hline $\mathrm{Cs}$ & 21,166 & 28,236 & 1.33 \\
\hline $\mathrm{Fe}$ & 1,172 & 1,787 & 1.52 \\
\hline $\mathrm{Na}$ & 91,550 & 166,796 & 1.82 \\
\hline $\mathrm{Ni}$ & 4,394 & 5,957 & 1.36 \\
\hline $\mathrm{P}$ & 1,941 & 3,336 & 1.72 \\
\hline $\mathrm{Sr}$ & 696 & 894 & 1.28 \\
\hline
\end{tabular}

Table 2-6. Gases Released from Ferrocyanide Simulant Reaction Tests

\begin{tabular}{|l|c|c|c|c|c|}
\hline \multicolumn{1}{|c|}{ Conditions } & $\begin{array}{c}\text { Nitrogen } \\
(\mathrm{mol} / \mathrm{mol})^{\circ}\end{array}$ & $\begin{array}{c}\text { Carbon } \\
\text { dioxide } \\
(\mathrm{mol} / \mathrm{mol})^{\circ}\end{array}$ & $\begin{array}{c}\text { Nitric } \\
\text { oxide } \\
(\mathrm{mol} / \mathrm{mol})^{\bullet}\end{array}$ & $\begin{array}{c}\text { Oxygen } \\
(\mathrm{mol} / \mathrm{mol})^{\circ}\end{array}$ & $\begin{array}{c}\text { Hydrogen } \\
(\mathrm{mol} / \mathrm{mol})^{\circ}\end{array}$ \\
\hline $\begin{array}{l}\text { Pres }=51.7 \text { atm } \\
\text { Temp }=68{ }^{\circ} \mathrm{C}\end{array}$ & 7.1 & 2.8 & 0.0 & 0.0 & 0.5 \\
\hline $\begin{array}{l}\text { Pres }=10.1 \text { atm } \\
\text { Temp }=60^{\circ} \mathrm{C}\end{array}$ & 5.3 & 2.1 & 2.5 & 0.0 & 0.0 \\
\hline
\end{tabular}

Moles of gas released per mole of ferrocyanide.

Planned Work for Subsequent Months. Identify the important parameters in the propagation screening tests. Define additional parametric and ferrocyanide/organic tests to be conducted and initiate the tests at FAI. Prepare the T Plant simulant and conduct calorimetry tests. Prepare additional U Plant 1 simulant and conduct dryout tests. Complete sample analysis of In Farm 1 residue samples to identify reaction products and determine the fraction of cesium released as aerosol.

- Milestone Status.

- December 31, 1992: Define parametric and aerosol sampling tests to be conducted at FAI using In Farm and U Plant flowsheet ferrocyanide waste simulants. Parametric tests and the scope of aerosol tests to be conducted 
at FAI were defined with Dr. H. K. Fauske, of FAI on December 10, 1992. The letter to FAI authorizing these tests was issued January 12, 1993.

January 29, 1993: Complete pressure parametric and confined scoping aerosol/propagation tests on the most reactive simulant at FAI.

- May 14, 1993: Prepare and ship T Plant and U Plant 1 simulants to FAI for calorimetric and dry out tests, respectively.

- June 30, 1993: Complete a report, approved for public release, on T Plant calorimetry and propagation tests, and U Plant dry out tests.

- July 30, 1993: Complete a report on parametric and selected aerosol tests on the most reactive (In Farm 1) flowsheet simulant at FAI and issue a test report that is approved for public release.

- September 30, 1993: Complete ferrocyanide/organic calorimetry scanning tests and issue a test report that is approved for public release.

\subsection{DEFENSE NUCLEAR FACILITIES SAFETY BOARD RECOMMENDATION 90-7.6 (EMERGENCY RESPONSE PLANNING)}

"The Board had recommended that an action plan be developed for the measures to be taken to neutralize the conditions that may be signaled by alarms.' Two types of measures are implied: actions to respond to unexpected degradation of a tank or its contents, and actions to be taken if an explosion were to occur. Your implementation plan stated that the current contingency plans . . . will be reviewed and revised if needed.' We do not consider that this proposed implementation of the Board's recommendation is adequately responsive. It is recommended that a written action plan founded on demonstrated principles be prepared as soon as possible, that would respond to indications of onset of abnormal temperatures or other unusual conditions in a ferrocyanide-bearing tank, to counter any perceived growth in hazard. A separate emergency plan should be formulated and instituted, covering measures that would be taken in event of an explosion or other event leading to an airborne release of radioactive material from the tanks, and that would protect personnel both on and off the Hanford Site. The Board believes that even though it is considered that the probability is small that such an event will occur, prudence dictates that steps be taken at this time to prepare the means to mitigate the unacceptable results that could ensue." 


\subsubsection{Action Plan for Response to Abnormal Conditions}

The Action Plan for Response to Abnormal Conditions in Hanford Radioactive Waste Tanks Containing Ferrocyanide (Cash and Thurman 1991a) was prepared in response to DNFSB recommendations. The action plan describes the steps to be taken if a temperature increase trend above the tank temperature baseline is measured in any of the ferrocyanide tanks. The document was revised in December 1991 and reissued as WHC-EP-0407, Rev. 1 (Cash and Thurman 1991b) to include the monitoring criteria and responses for abnormal levels of flammable and toxic gases, as well as the reporting requirements if established criteria are exceeded.

Also addressed in this section are actions in response to other abnormal conditions that might be encountered with the ferrocyanide tanks, such as a leak to the environment. Of the 24 ferrocyanide tanks, 14 are classified as assumed leakers, including 241-T-101, which was added to the assumed leaker list of tanks on October 4, 1992. Six of the assumed leaker tanks have not been interim stabilized. Eight tanks still require some pumping to be classified as interim stabilized. Authorization to pump these tanks must be granted by DOE because the activity involves the Ferrocyanide USQ. This authorization requires that SA and EA documentation be prepared for this activity. The status of the SA and EA was discussed in Section 4.2.5.

- Progress During the Reporting Period. Both the SA and the EA for removing pumpable liquids from ferrocyanide tanks were submitted to DOE for review on September 30, 1992. Comments were received on the documents in early January and they were revised and resubmitted at the end of January. Additional comments on the EA were received from DOE on March 31, 1993, and these have now been addressed.

No further decreases in liquid level in tank 241-T-101, as measured by the Food Instrument Corporation gauge and/or manual tape, have occurred since plans for pumping were initiated. Vapor sampling and photographs of the interior of the tank were completed during the quarter. A saltwell screen and submersible pump were also installed, and pumping was initiated on March 12 after authorization was received from DOE.

On April 1, 1993, Westinghouse Hanford notified DOE that reportable quantities may have leaked from tank 241-BX-111. Westinghouse Hanford has evaluated the surveillance data available on this tank and has declared this tank to be an "assumed re-leaker" since the tank had already been declared to be an "assumed leaker" several years ago. Plans are now underway to pump this tank as well. 
- Planned Work for Subsequent Months. A request for authorization for stabilization and emergency pumping of the ferrocyanide tanks will be submitted to DOE in April. Comments received from DOE on the EA will be incorporated and the dccument will be resubmitted by early May.

Plans for interim stabilization of the seven ferrocyanide tanks (excluding 241-T-101) remaining to be pumped will proceed as soon as authorization is received from DOE. Each tank will undergo a thorough readiness review prior to commencing pumping operations.

- Problem Areas and Action Taken. None.

- Milestone Status.

- August 31, 1992: Issue a draft SA for saltwell pumping (stabilization) of ferrocyanide tanks to DOE. This same SA will be applicable to tanks that may need to be pumped because of a leak. This milestone was met on September 30, 1992.

- September 30, 1992: Recommendations will be issued on the feasibility and safety of stabilizing single shell ferrocyanide tanks. These recommendations will also address actions to be taken if a tank shows evidence of a leak. The recommendation letter, together with the safety assessment on stabilization of ferrocyanide tanks, was delivered to DOE on September 30, 1992.

- December 31, 1992: Incorporate comments into the SA and EA documents as appropriate and submit revised documents to DOE for review. The EA was revised and resubmitted to DOE in December, and the SA was not submitted until January 25, 1993. A second revision of the EA was transmitted on January 29, 1993.

- February 1, 1993: Receive authorization from DOE, based upon revised $\mathrm{SA}$ and EA documentation, to proceed with pumping of leaking ferrocyanide tank 241-T-101. The scheduled date for initiation of pumping was changed to the first part of March 1993. Authorization was received in March and pumping commenced on March 12, 1993.

- March 31, 1994: Complete an evaluation report to determine which gases, if any, need to be continuously monitored on selected ferrocyanide tanks (see also Section 2.3). 


\subsubsection{Response to an Airborne Release From a Ferrocyanide Tank}

If a radioactive release from a ferrocyanide tank were to occur, it would be detected by one or more radiation monitoring systems. Significant airborne or ground surface releases that spread beyond the immediate tank or tank farm would be detected by the tank farm area radiation detectors. These monitoring systems are on all tank farms. An emergency involving an underground radioactive waste storage tank is a unique event with potentially serious consequences both onsite and offsite. The DOE and Westinghouse Hanford have analyzed the potential impacts of an event involving one of these tanks, and have taken additional steps in order that emergency personnel can take mitigating actions in a timely fashion. These analyses resulted in development of the Tank Farm Emergency Response Stabilization Plan (WHC 1991) in March 1991. The plan includes predetermined mitigative actions for terminating the emergency phase and providing a transition to the recovery phase. Acknowledging that an event could range from minor to major releases, the plan addresses responses in four distinct and defined steps that will cover the range of consequences. The Stabilization Plan provides quick, preplanned actions that can be used to stabilize an emergency event at an underground radioactive waste storage tank.

- Progress During Reporting Period. As noted in previous reports, all of the planned milestones for this task were completed.

- Planned Work For Subsequent Months. None planned.

- Problem Areas and Action Taken. None.

- Milestone Status. None applicable. 
This page intentionally left blank. 


\subsection{SCHEDULES}

The schedules presented in this section are those provided by the revised implementation plan, WHC-EP-0415, Rev. 1 (Borsheim et al. 1992). The schedules have been statused for the second quarter of FY 1993, ending March 31, 1992. Work on the Ferrocyanide Safety Program is shown for FY 1991 through FY 1994. Because the scope of some of the program activities has changed over the past two years, it is appropriate that grogress be tracked against this new schedule.

The new schedule was expanded to four pages, and is laid out in a slightly different format that is easier to read. Activities that have started or been completed are indicated by triangles that are filled in. Work indicated by open triangles has either not started or has not been completed. A status line will be drawn each quarter showing the progress completed on each activity. 
WHC-EP-0474-8

Schedule 3-1. (Sheet 1 of 4)

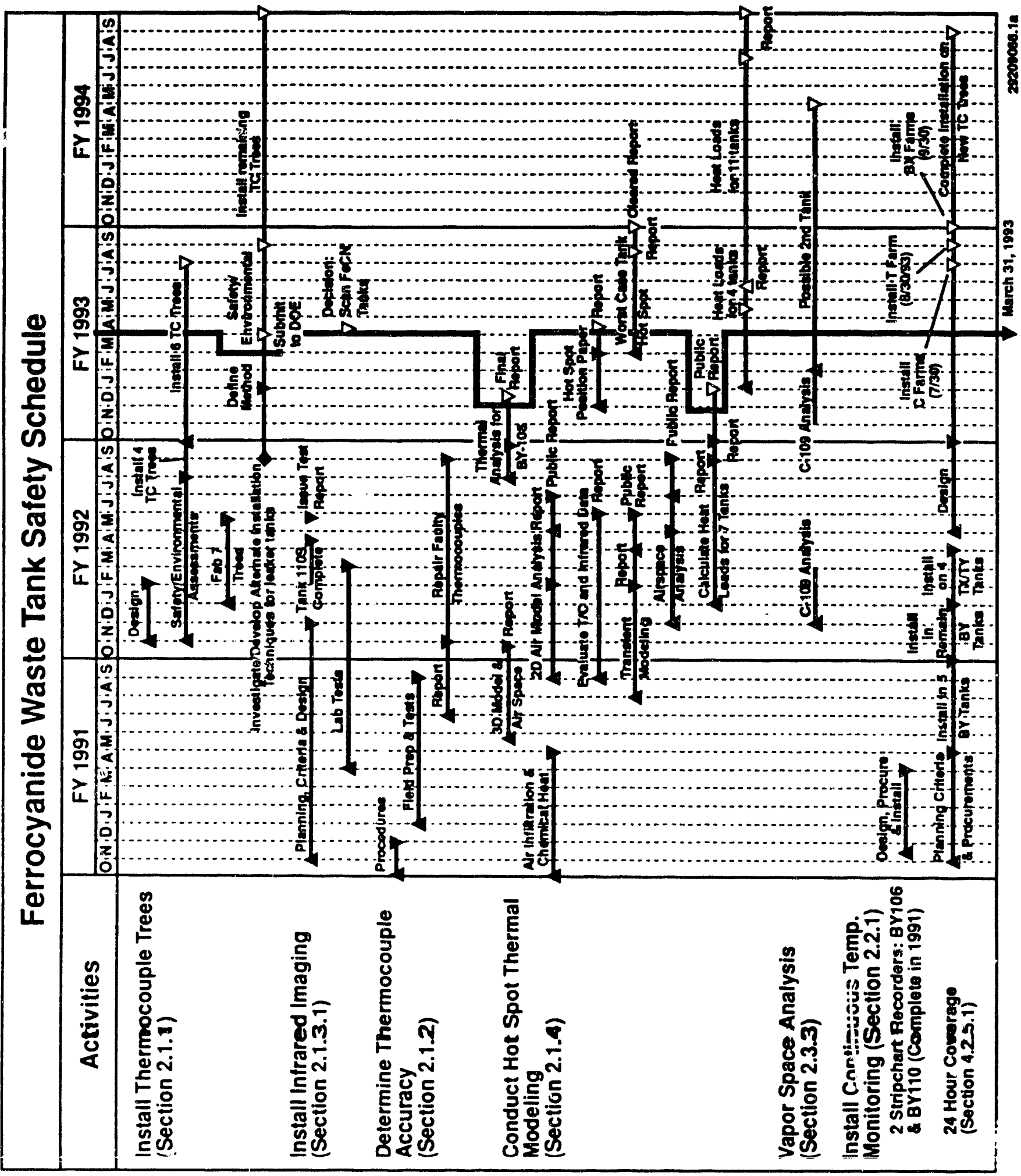


Schedule 3-1. (Sheet 2 of 4)

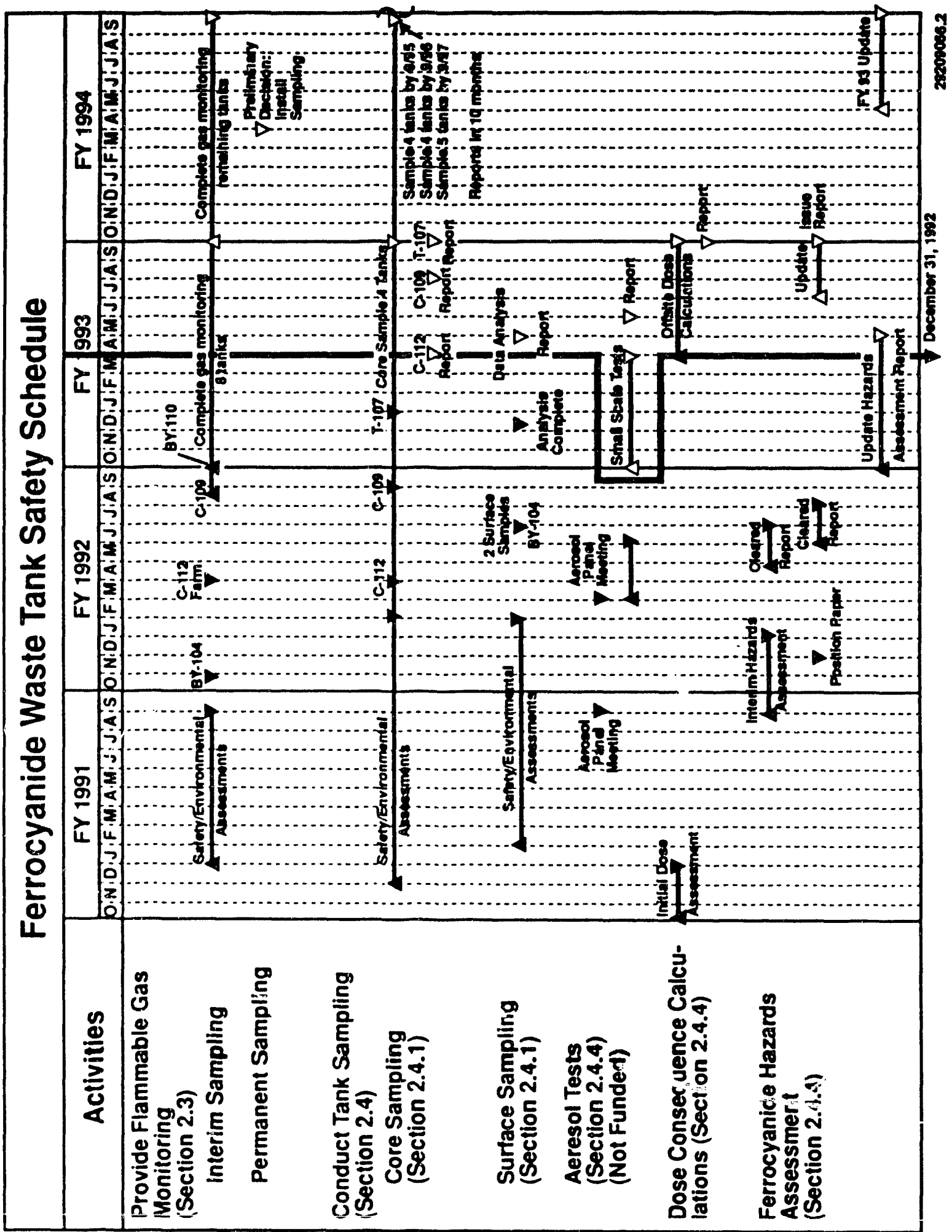


Schedule 3-1. (Sheet 3 of 4)

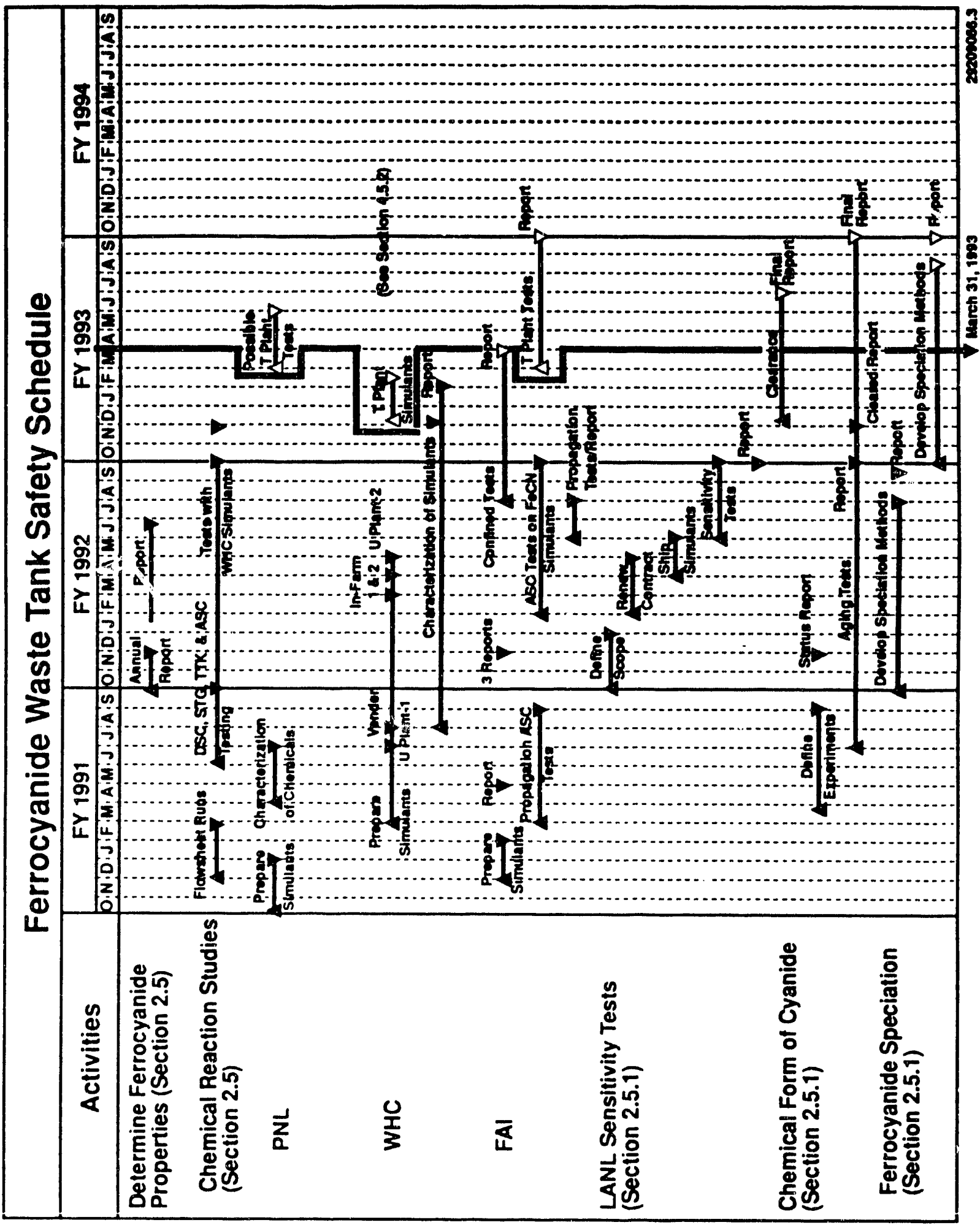


Schedule 3-1. (Sheet 4 of 4)

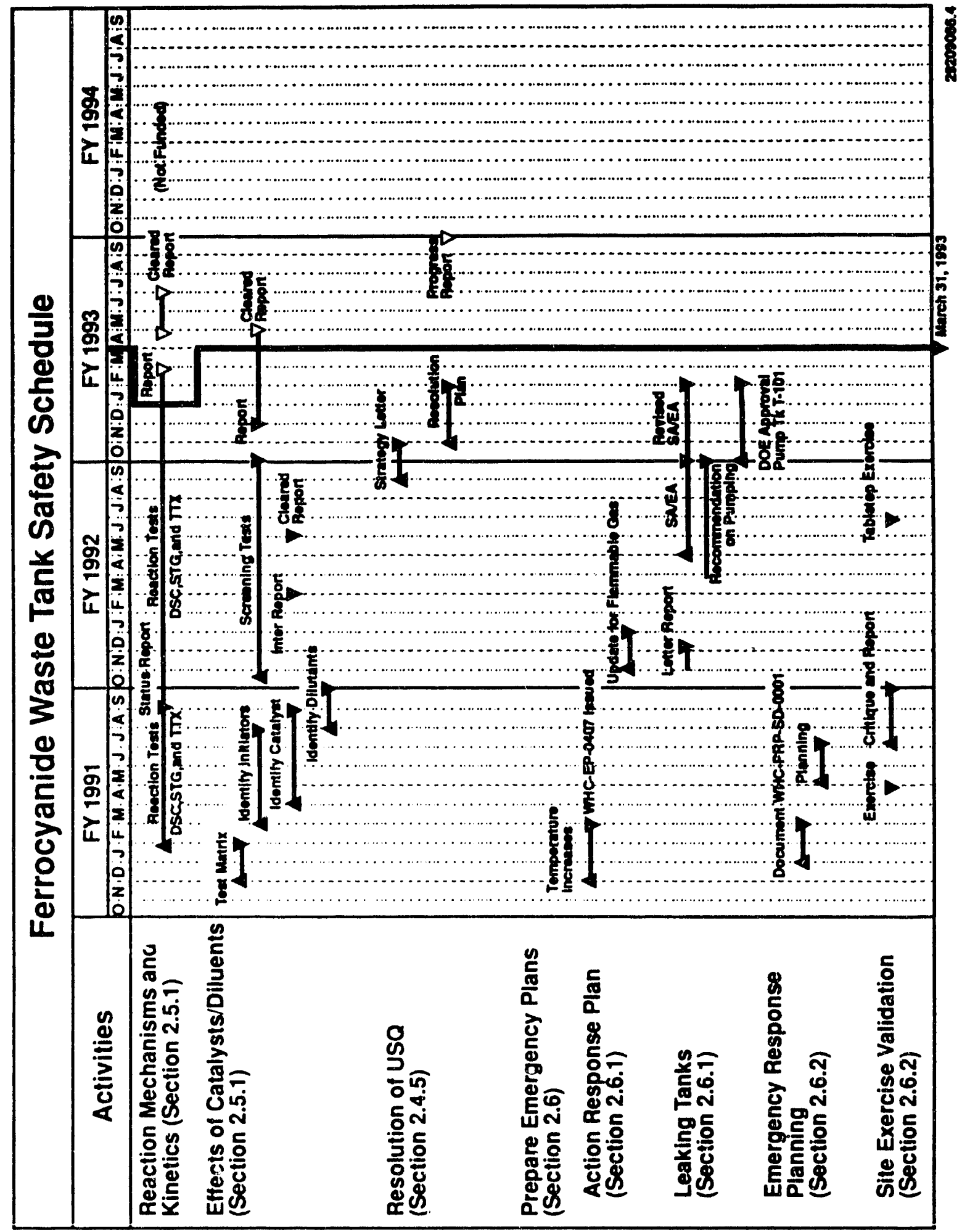


This page intentionally left blank. 


\subsection{REFERENCES}

Bergmann, L. M., 1986, Single-Shell Tank Isolation Safety Analysis Report, WHC-SD-WM-SAR-006, Rev. 2, Westinghouse Hanford Company, Richland, Washington.

Borsheim, G. L., and B. C. Simpson, 1991, An Assessment of the Inventories of the Ferrocyanide Watch List Tanks, WHC-SD-WM-ER-133, Rev. 0, Westinghouse Hanford Company, Richland, Washington.

Borsheim, G. L., R. J. Cash, and G. T. Dukelow, 1992, Implementation Plan for the Defense Nuclear Facilities Safety Board Recommendation 90-7, WHC-EP-0415, Rev. 1, Westinghouse Hanford Company, Richland, Washington.

Bryan, S. A., K. H. Pool, L. L. Burger, C. D. Carlson, J. L. Ryan, R. D. Scheele, and J. M. Tingey, 1992, Ferrocyanide Safety Project-- Task 3.5 - Cyanide Species Analytical Methods Development, FY 1992 Annual Report, PNL-8399, Pacific Northwest Laboratory, Richland, Washington.

Burger, L. L., 1989, Complexant Stability Investigation, Task 1-Ferrocyanide Solids, PNL-5441, Pacific Northwest Laboratory, Richland, Washington.

Burger, L. L., and R. D. Scheele, 1988, Interim Report - Cyanide Safety Studies, PNL-7175, Pacific Northwest Laboratory, Richland, Washington.

Cash, R. J., 1991, Implementation Plan for the Defense Nuclear Facilities Safety Board Recommendation 90-7, WHC-EP-0415, Westinghouse Hanford Company, Richland, Washington.

Cash, R. J., H. Babad, and A. K. Postma, 1992a, Ferrocyanide Containing Tanks: A Study in Risk Evaluation, WHC-SA-1405-FP, Westinghouse Hanford Company, Richland, Washington.

Cash, R. J., G. T. Dukelow, C. R. Miska, and C. J. Forbes, 1992b, Quarterly Report on Defense Nuclear Facilities Safery Board Recommendation 90-7 for Period Ending September 30, 1992, WHC-EP-0474-6, Westinghouse Hanford Company, Richland, Washington.

Cash, R. J., G. T. Dukelow, and C. J. Forbes, 1993, Quarterly Report on Defense Nuclear Facilities Safery Board Recommendation 90-7 for Period Ending December 31, 1992, WHC-EP-0474-7, Westinghouse Hanford Company, Richland, Washington. 
Cash, R. J., and G. T. Dukelow, 1992, Quarterly Report on Defense Nuclear Facilities Safety Board Recommendation 90-7 for the Period Ending June 30, 1992, WHC-EP-0474-5, Westinghouse Hanford Company, Richland, Washington.

Cash, R. J., and J. M. Thurman, 1991a, Action Plan for Response to Abnormal Conditions in Hanford Site Radioactive Waste Tanks Containing Ferrocyanide, WHC-EP-0407, Westinghouse Hanford Company, Richland, Washington.

Cash, R. J., and J. M. Thurman, 1991b, Action Plan for Response to Abnormal Conditions in Hanford Site Radioactive Waste Tanks Containing Ferrocyanide, WHC-EP-0407, Rev. 1, Westinghouse Hanford Company, Richland, Washington.

Deaton, D. E., 1990, Unusual Occurrence-Unreviewed Safety Questions Regarding Tanks Containing Ferrocyanide, WHC-90-B003-R1, Update 10-22-90, Westinghouse Hanford Company, Richland, Washington.

DOE, 1986, Safety of Nuclear Facilities, DOE Order 5480.5, U.S. Department of Energy, Washington, D.C.

DOE, 1987, Final Environmental Impact Statement - Disposal of Hanford Defense HighLevel, Transuranic, and Tank Wastes, Vols. 1-5, DOE/EIS-0113, U.S. Department of Energy, Washington, D.C.

DOE, 1990, "DOE to Develop Supplemental Environmental Impact Statement for Hanford," press release (October 9, 1990), U.S. Department of Energy, Washington, D.C.

DOE, 1991, Unreviewed Safety Questions, DOE Order 5480.21, U.S. Department of Energy, Washington, D.C.

Dunnett, C. W., 1955, "A Multiple Comparison Procedure for Comparing Several Treatments with a Control." Journal American Statistical Association, 50:1096-1121.

Ecology, EPA, and DOE, 1989, Hanford Federal Facility Agreement and Consent Order, 2 vols, as amended, Washington State Department of Ecology, U.S. Environmental Prntection Agency, and U.S. Department of Energy, Olympia, Washington.

Fauske, H. K., 1992, Adiabatic Calorimetry and Reaction Propagation Rate Tests with Synthetic Ferrocyanide Materials Including U Plant 1, U Plant 2, In Farm 1, In Farm 2 and Vendor Procured Sodium Nickel Ferrocyanide, WHC-SD-WM-RPT-254, Rev. 0, Westinghouse Hanford Company, Richland, Washington. 
FR, 1990, "Implementation Plan for Recommendation 90-3 at the Department of Energy's Hanford Site, Washington," Federal Register, Defense Nuclear Facilities Safety Board Recommendation 90-7, Vol. 55, No. 202, pp. 42243 - 42244.

Grigsby, J. M., D. B. Bechtold, G. L. Borsheim, M. D. Crippen, D. R. Dickinson, G. L. Fox, D. W. Jeppson, M. Kummerer, J. M. McCormack, A. Padilla, B. C. Simpson, and D. D. Stepnewski, 1992, Ferrocyanide Waste Tank Hazard Assessment-Interim Report, WHC-SD-WM-RPT-032, Rev. 1, Westinghouse Hanford Company, Richland, Washington.

Hallen, R. T., L. L. Burger, R. L. Hockey, M. A. Lilga, R. D. Scheele, and J. M. Tingey, 1992, Ferrocyanide Safety Project FY 1991 Annual Report, PNL-8165, Pacific Northwest Laboratory, Richland, Washington.

Hanlon, B. M., 1993, Tank Farm Surveillance and Waste Tank Summary Report for December 1992, WHC-EP-0182-57, Westinghouse Hanford Company, Richland, Washington.

Henkin, H., and R. McGill, 1952, "Rates of Explosive Decomposition of Explosives Experimental and Theoretical Kinetic Study as a Function of Temperature." Ind. Eng. Chem. 44:1391.

Jeppson, D. W., and J. J. Wong, 1993, Ferrocyanide Waste Simulant Characterization, WHC-EP-0631, Westinghouse Hanford Company, Richland, Washington.

Kazimi, M. S., C. S. Abrams, D. O. Campbell, F. N. Carlson, M. W. First, C. W. Forsberg, B. C. Hudson, T. S, Kress, T. E. Larson, D. T. Oakley, G. E. Schmauch, S. E. Slezak, and A. S. Veletsos, 1992, Approach to Resolution of Safety Issues Associated with Ferrocyanides in the Hanford Waste Tanks, High-Level Waste Tanks Advisory Panel, U.S. Deprstment of Energy, Washington, D.C.

Lilga, M. A., M. R. Lumetta, W. R. Riemath, R. A. Romine, and G. F. Schiefelbein, 1992, Ferrocyanide Safery Project Subtask 3.4 - Aging Studies FY 1992 Annual Report, PNL-8387, Facific Northwest Laboratory, Richland, Washington.

Peach, J. D., 1990, "Consequences of Expiusion of Hanford's Single-Shell Tanks Are Understated," (Letter B-241479 to C. M. Synar, Chairman of Environment, Energy and Natural Resources Subcommittee, Committee on Government Operations, House of Representatives), GAO/RCED-91-34, General Accounting Office, Washington, D.C.

Postma, A. K., H. Babad, R. J. Cash, and J. L. Deichman, 1992, Current Understanding of the Safety of Storing High-Level Waste Containing Ferrocyanide at the Hanford Site, WHC-EP-0531, Rev. 1, Westinghouse Hanford Company, Richland, Washington. 
Scheele, R. D., L. L. Burger, J. M. Tingey, S. A. Bryan, G. L. Borsheim, B. C. Simpson, R. J. Cash, and H. H. Cady, 1991, Ferrocyanide-Containing Waste Tanks: Ferrocyanide Chemistry and Reactivity, in the Proceedings of Environmental Restoration 91, University of Arizona, Tucson, Arizona.

Scheele, R. D., S. A. Bryan, J. W. Johnston, J. M. Tingey, L. L. Burger, and R. T. Hallen, 1992, Hanford Ferrocyanide Waste Chemistry and Reactivity - Preliminary Catalyst and Initiator Screening Studies, PNL-8089, Pacific Northwest Laboratory, Richland, Washington.

WHC, 1991, Tank Farm Stabilization Plan for Emergency Response, WHC-SD-PRP-TI-001, Rev 0, Westinghouse Hanford Company, Richland, Washington.

WHC, 1991a, Waste Characterization Plan for the Hanford Site Single-Shell Tanks, WHC-EP-0210, Revisions 1, 2, and 3, Westinghouse Hanford Company, Richland, Washington. 


\section{APPENDIX A}

\section{LIST OF FERROCYANIDE TANKS AND}

ANALYTES FOR TANK 241-C-112 
WHC-EP-0474-8

This page intentionally left blank. 
Table A-1. Summary of Contents and Status of Ferrocyanide Tanks.

\begin{tabular}{|c|c|c|c|c|c|}
\hline Tank & $\begin{array}{c}\text { Total waste } \\
\text { volume } \\
(1,000 \mathrm{gal})\end{array}$ & $\begin{array}{c}\mathrm{FeCN}^{\mathrm{b}} \\
(1,000 \mathrm{~g} \mathrm{~mol})\end{array}$ & $\begin{array}{c}\text { Heat load }(1,000 \\
\text { Btu/h })^{\mathrm{c}}\end{array}$ & $\begin{array}{l}\text { Maximum } \\
\text { temp. } \\
\left({ }^{\circ} \mathrm{C}\right)\left({ }^{\circ} \mathrm{F}\right)\end{array}$ & Status of $\tan k s^{e}$ \\
\hline BX-102 & 96 & $<1$ & $<10$ & $17 \quad 63$ & S; AL \\
\hline BX-106 & 45 & $<1$ & $<10$ & 17 & NS; Sound \\
\hline$B X-110$ & 199 & $<1$ & $<10$ & $18 \quad 64$ & S; AL \\
\hline BX-111 & 230 & $<1$ & $<10$ & 20 & NS; AL \\
\hline BY-101 & 387 & $<1$ & 8.2 & 24 & S; Sound \\
\hline BY -103 & 400 & 66 & 8.6 & 28 & NS; AL \\
\hline BY -104 & 406 & 83 & $5.5-11.0^{d}$ & $\begin{array}{ll}54 & 129 \\
46^{f} & 115\end{array}$ & S; Sound \\
\hline BY -105 & 503 & 36 & $4.0-8.0^{d}$ & $\begin{array}{ll}46 & 115 \\
50 & 122\end{array}$ & NS; AL \\
\hline BY-106 & 642 & 70 & $5.5-11.0^{d}$ & $54 \quad 130$ & NS; AL \\
\hline BY -107 & 266 & 42 & 14.5 & 35 & $S ; A L$ \\
\hline BY -108 & 228 & 58 & $4.4-8.8^{d}$ & $43 \quad 110$ & $S ; A L$ \\
\hline BY -110 & 398 & 71 & $4.0-8.0^{d}$ & $\begin{array}{ll}49 & 120 \\
43^{f} & 109\end{array}$ & S; Sound \\
\hline BY-111 & 459 & 6 & $2.4-4.8^{d}$ & $30 \quad 86$ & S; Sound \\
\hline BY -112 & 291 & 2 & $<10$ & 28 & S; Sound \\
\hline C-108 & 66 & 25 & $<10$ & $22 \quad 72$ & S; Sound \\
\hline$C-109$ & 66 & 30 & $3.5-7.0^{d}$ & $\begin{array}{ll}23 & 74 \\
26^{\mathrm{f}} & 78\end{array}$ & S; Sound \\
\hline$C-111$ & 57 & 33 & $<10$ & 71 & $S ; A L$ \\
\hline$C-112$ & 109 & 31 & $<10$ & $\begin{array}{ll}29 & 84 \\
29^{f} & 85\end{array}$ & S; Sound \\
\hline$T-101$ & 133 & $<1$ & $<10$ & 21 & NS; AL \\
\hline $\mathrm{T}-107$ & 180 & 5 & $<10$ & 66 & NS; AL \\
\hline $\mathrm{TX}-118$ & 347 & $<3$ & 4.9 & 78 & S; Sound \\
\hline
\end{tabular}


Table A-1. Summary of Contents and Status of Ferrocyanide Tanks".

\begin{tabular}{|c|c|c|c|c|c|}
\hline Tank & $\begin{array}{c}\text { Total waste } \\
\text { volume } \\
(1,000 \text { gal })\end{array}$ & $\begin{array}{c}\mathrm{FeCN}^{\mathrm{b}} \\
(1,000 \mathrm{~g} \mathrm{~mol})\end{array}$ & $\begin{array}{c}\text { Heat load }(1,000 \\
\text { Btu/h })^{\mathrm{c}}\end{array}$ & $\begin{array}{l}\text { Maximum } \\
\text { temp. } \\
\left({ }^{\circ} \mathrm{C}\right)\left({ }^{\circ} \mathrm{F}\right)\end{array}$ & Status of $\tan k s^{\circ}$ \\
\hline TY-101 & 118 & 23 & $<10$ & 18 & S; AL \\
\hline TY -103 & 162 & 28 & $<10$ & 19 & S; AL \\
\hline TY-104 & 46 & 12 & $<10$ & 63 & $S ; A L$ \\
\hline Totals & $5,834,000 \mathrm{gal}$ & $624 \mathrm{~K}$ g-mol. & & & \\
\hline
\end{tabular}

'Based on information contained in monthly reports (WHC-EP-0182-XX)

(Hanlon 1993); temperature data as of March 1993.

'Inventories from Borsheim and Simpson, 1991.

'Heat load values are conservatively high; new values will be calculated.

'New heat load data as of September 1992, showing low and high and of range based upon variances in thermal conductivities for waste and soil.

'S - Interim Stabilized Tank; NS - Not Stabilized; AL - Assumed Leaker Tank; Sound Non-Leaking Tank.

'Temperatures recorded for new thermocouple trees installed in September 1992. 


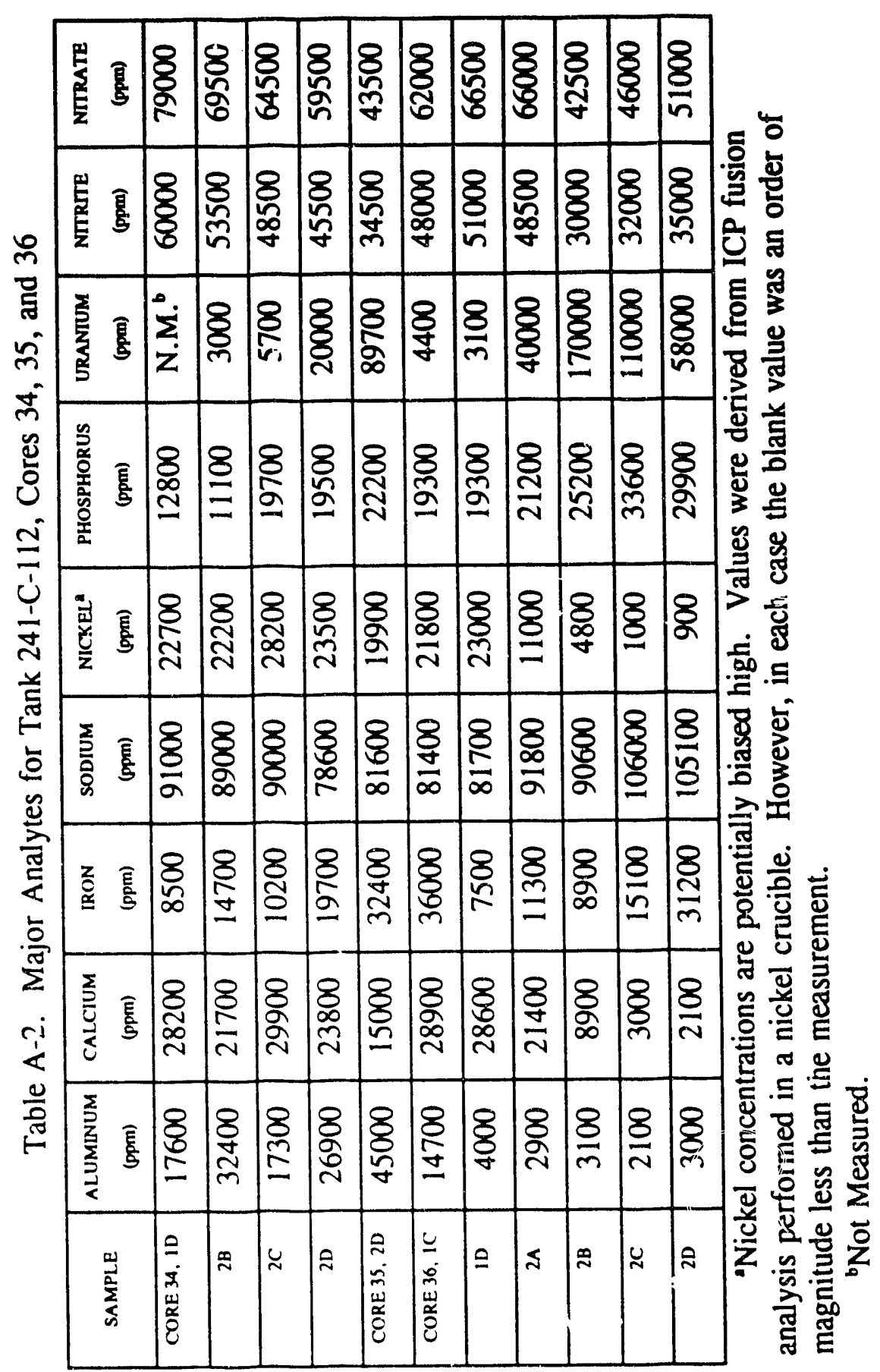




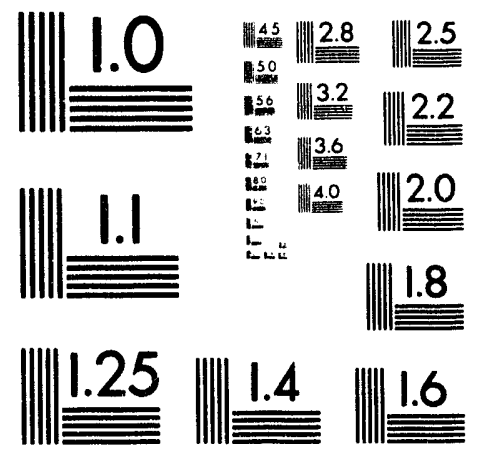



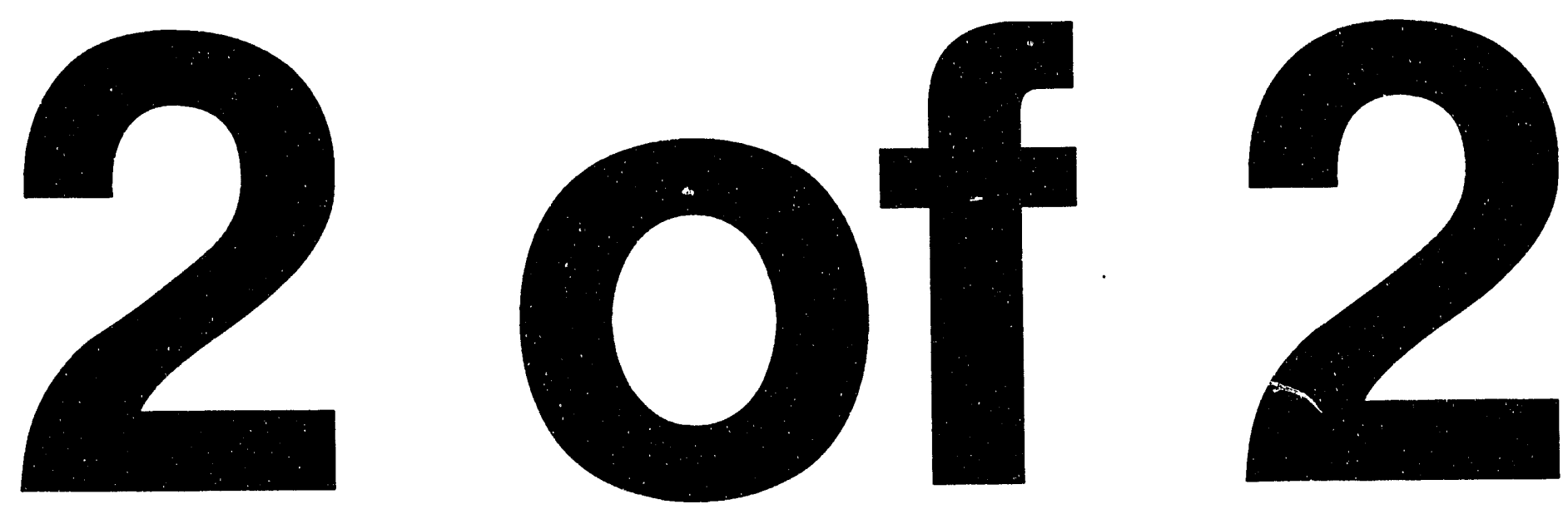
This page intentionally left blank. 


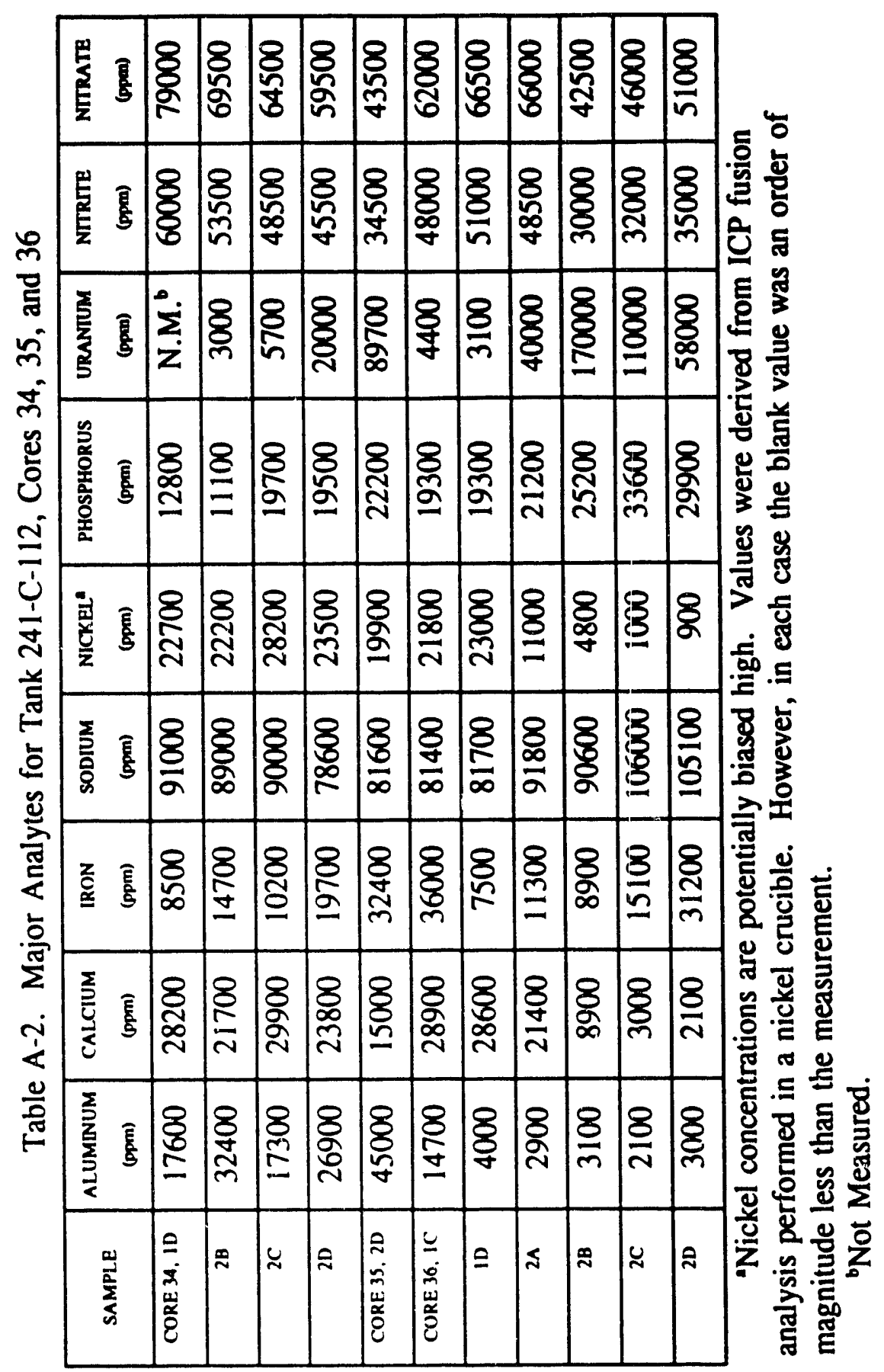


WHC-EP-0474-8

APPENDIX B

METRIC CONVERSION CHART

B-1 
WHC-EP-0474-8

This page intentionally left blank. 
WHC-EP-0474-8

Table B-1. Metric Conversion Chart.

\begin{tabular}{|c|c|c|c|c|c|}
\hline \multicolumn{3}{|c|}{ Into Metric } & \multicolumn{3}{|c|}{ Out of Metric } \\
\hline If You Know & Multiply By & To Get & If You Know & Multiply By & To Get \\
\hline \multicolumn{3}{|c|}{ Length } & \multicolumn{3}{|c|}{ Length } \\
\hline in. & 2.54 & $\mathrm{~cm}$ & $\mathrm{~mm}$ & 0.04 & in. \\
\hline $\mathrm{ft}$ & 30.48 & $\mathrm{~cm}$ & $\mathrm{~cm}$ & 0.4 & in. \\
\hline \multicolumn{3}{|c|}{ Mass (weight) } & \multicolumn{3}{|c|}{ Mass (weight) } \\
\hline lb & 0.453515 & kg & kg & 2.2 & lb \\
\hline \multicolumn{3}{|c|}{ Volume } & \multicolumn{3}{|c|}{ Volume } \\
\hline gal & 3.78541 & L & L & 0.264172 & gal \\
\hline \multicolumn{3}{|c|}{ Temperature } & \multicolumn{3}{|c|}{ Temperature } \\
\hline $\begin{array}{l}\text { Fahrenheit } \\
\left({ }^{\circ} \mathrm{F}\right)\end{array}$ & $\begin{array}{c}\text { Subtract } 32 \\
\text { then multiply } \\
\text { by } \\
0.55555 \ldots\end{array}$ & $\begin{array}{l}\text { Celsius } \\
\left({ }^{\circ} \mathrm{C}\right)\end{array}$ & Celsius $\left({ }^{\circ} \mathrm{C}\right)$ & $\begin{array}{l}\text { Multiply by } \\
1.8, \text { then add } \\
32\end{array}$ & Fahrenheit $\left({ }^{\circ} \mathrm{F}\right)$ \\
\hline
\end{tabular}


WHC-EP-0474-8

This page intentionally left blank. 


\section{DISTRIBUTION}

\section{Number of Copies}

\section{OFESTE}

U.S. Department of Energy

\section{EM-35, Trevion II}

Washington, D.C. 20585

John C. Tseng

1

\section{U.S. Department of Energy}

Savannah River Operations Office

P.O. Box A

Aiken, South Carolina 29808

Thomas C. Temple

1

Charles S. Abrams

1987 Virginia

Idaho Falls, ID 83404

David O. Campbell

102 Windham Road

Oak Ridge, TN 37830

1

Fred N. Carlson 6965 North 5th West

Idaho Falls, ID 83401

1

Donald T. Oakley

409 12th Street SW, Suite 310

Washington, DC 20024-2188

1

Arlin K. Postma

3640 Ballard Road

Dallis, Oregon 97338

1

William R. Prindle

1556 Crestline Drive

Santa Barbara, CA 93105 


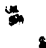

\section{DISTRIBUTION (Continued)}

Number of Copies

\section{OFFSITE}

1

1

1

2

1

1
Alfred Schneider 5005 Hidden Branches Drive

Dunwoody, GA 30338

Air Products \& Chemicals. Inc. 7201 Hamilton Blvd

Allentown, PA 18195-1501

George E. Schmauch

Battelle Columbus Laboratories

505 King Avenue

Columbus, $\mathrm{OH}$ 43201-2693

James A. Gieseke

Brookhaven National Laboratory

Upton, NY 11973

Kamal K. Bandyopadhyay

Morris Reich

Design Science Inc.

163 Witherow Road

Sewickley, PA 15143

Gary Powers

Fauske and Associates, Inc.

16W070 W. 83rd St.

Burr Ridge, IL 60521

Hans K. Fauske 


\section{DISTRIBUTION (Continued)}

\section{Nuinber of Copies}

\section{QFESITE}

1

1

1

1

4

\section{Elorida State University}

Department of Chemistry B-164

Tallahassee, FL 32306

Greg R. Choppin

Harvard University

295 Upland Avenue

Newton Highlands, MA 02161

Melvin W. First

Hazards Research Corporation 200 Valley Rcad, Suite 301

Mt. Arlington, NJ 07856

Chester Grelecki

Lawrence Livermore National Laboratory

P.O. Box 808, L-221

Livermore, CA 94550

Billy C. Hudson

Los Alamos National Laboratory

P.O. Box 1663

Los Alamos, NM 87545

Steve F. Agnew

Steve W. Eisenhawer

Thomas E. Larson

L. Harold Sullivan 


\section{DISTRIBUTION (Continued)}

\section{Number of Copies}

\section{OFESITE}

1

MIT/Department of Nuclear Engineering

77 Massachusetts Ave.

Room 24-102

Cambridge, MA 02139

Mujid S. Kazimi

1

Nuclear Consulting Services, Inc.

P.O. Box 29151

Columbus, OH 43229

J. Louis Kovach

1

Qak Ridge National Laboratory

Emory D. Collins

P.O. Box 2008

7930, MS-6385

Oak Ridge, TN 37831-6385

1 Charles W. Forsberg

P.O. Box 2008

MS-6495

Oak Ridge, TN 37831-6495

1

Thomas S. Kress

P.O. Box 2009

9108, MS-8088

Oak Ridge, TN 37831-8088

1 Rice University

5211 Paisley

Houston, TX 77096

Andrew S. Veletsos 


\section{DISTRIBUTION (Continued)}

\section{Number of Copies}

\section{OFFSTTE}

1

4

1

1

1
Sandia National Laboratory

P.O. Box 5800

Albuquerque, NM 87185

Scott E. Slezak

Science Applications International Corporation

12850 Middlebrook Road

Trevion I, Suite 300

Germantown, MD 20874

Ray S. Daniels (3)

John M. Saveland

University of South Carolina

Department of Electrical and Computer Engineering

Swearingen Engineering Center

Columbia, SC 29208

Joseph S. Byrd

University of Washington

Center for Process Analytical Chemistry

Chemistry Department BG-10

Seattle, WA 98195

Bruce R. Kowalski

Vanderbilt University

P.O. Box 1596, Station B

Nashville, TN 37235

Frank L. Parker 


\section{DISTRIBUTION (Continued)}

\section{Number of Copies}

\section{OFESTTE}

State of Washington

Department of Ecology

P. O. Box 47600

Olympia, WA $98504-7600$

Scott McKenny

ONSITE

13

U.S. Department of Energy Richland Field Office

R. F. Christensen (8)

A4-02

R. E. Gerton

A4-02

A. G. Krasopoulos

A5-55

Public Reading Room

A1-65

RL Docket File (2)

8

Pacific Northwest Laboratory

R. T. Allemann

K7-15

S. A. Bryan

P7-25

B. M. Johnson

K1-78

M. A. Lilga

P8-38

R. D. Scheele

P7-25

G. F. Schiefelbein

P8-38

D. M. Strachan

K2-38

PNL Technical Files

K1-11

98

Westinghouse Hanford Company

H. Babad

R2-08

D. B. Bechtold

T6-50

J. R. Bell

R3-09

J. B. Billetdeaux

R2-08

R. J. Blanchard

R1-17

T. D. Blankenship

B1-58 


\section{DISTRIBUTION (Continued)}

\section{Number of Copies}

\section{ONSITE}

\section{Westinghouse Hanford Company (Continued)}

D. C. Board

G. L. Borsheim

R2-11

V. C. Boyles

R1-49

S. L. Bradley

B3-06

J. G. Burk

B3-25

R. J. Cash (5)

R2-32

M. D. Crippen

L5-31

G. M. Christensen

H4-21

R. D. Crowe

H4-62

S. J. Dechte-

R2-50

C. DeFigh-Price

R2-31

J. L. Deichman

B1-59

D. R. Dickinson

L5-31

G. T. Dukelow (2)

R2-32

G. L. Dunford

R1-51

C. J. Forbes

R1-08

K. D. Fowler

R2-11

G. L. Fox

L5-01

G. T. Frater

R1-51

J. C. Fulton

R2-31

K. A. Gasper

R2-08

S. D. Godfrey

R1-51

J. M. Grigsby

H4-62

T. W. Halverson

R2-52

D. G. Hamrick

R1-51

H. D. Harmon

R2-52

J. M. Held

R3-12

J. M. Henderson

S4-55

J. D. Hopkins

R2-11

R. D. House

R2-83

M. W. Howard

R2-08

L. L. Humphreys

R2-50

M. N. Islam

R3-08

D. W. Jeppson

L5-31

J. R. Jewett

T6-50

D. R. Johnson

R2-08

N. W. Kirch

R2-11 
DISTRIBUTION (Continued)

Number of Copies

ONSITE
Westinghouse Hanford Company (Continued)

W. L. Knecht

C. A. Kuhlman

M. Kummerer

D. L. Lenseigne

D. A. Marsh

J. D. McCormack

J. M. McLaren

J. E. Meacham

S. J. Mech

J. P. Menard

J. W. Neskas

N. J. Milliken

A. F. Noonan

P. C. Ohl

D. Pabst

M. A. Payne

R. S. Popielarczyk

D. N. Price

J. G. Propson

R. E. Raymond

I. E. Reep

F. R. Reich

E. L. Renner

D. A. Reynolds

D. C. Richardson

J. H. Roecker

C. C. Scaief

C. P. Schroeder

M. Hi. Shannon

D. Sherwood

N. L. Simon

B. C. Simpson

S. R. Tifft

H. Toffer

J. D. Thomson

R. E. Vandercook

W. T. Watson
HO-34

B3-30

H4-62

R2-75

A3-05

L5-31

HO-34

R2-32

L5-55

R2-40

R2-11

H4-62

R2-12

H5-09

B2-35

R2-50

R1-30

R2-14

R2-18

R1-80

R2-08

L5-63

R2-08

R2-11

R2-31

B1-59

L7-06

L7-06

H4-61

B5-01

R2-78

R2-12

H6-16

H0-38

R1-30

S6-17

H0-38 


\section{DISTRIBUTION (Continued)}

Number of Copies

\section{ONSITE Westinghouse Hanford Company (Continued)}

$\begin{array}{ll}\text { R. K. Welty R1-80 } & \text { R }\end{array}$

W. P. Whiting B3-25

J. C. Wiborg H4-60

W. D. Winkelman L5-55

D. D. Wodrich R2-31

D. D. Wodrich B1-59

W. F. Zuroff $\quad$ R2-14

Central Files L8-04

Document Processing and

Distribution (2)

EDMC

L8-15

Information Release

Administration (3)

H6-08

TFIC

R1-08

R1-20 
WHC-EP-0474-8

This page intentionally left blank. 

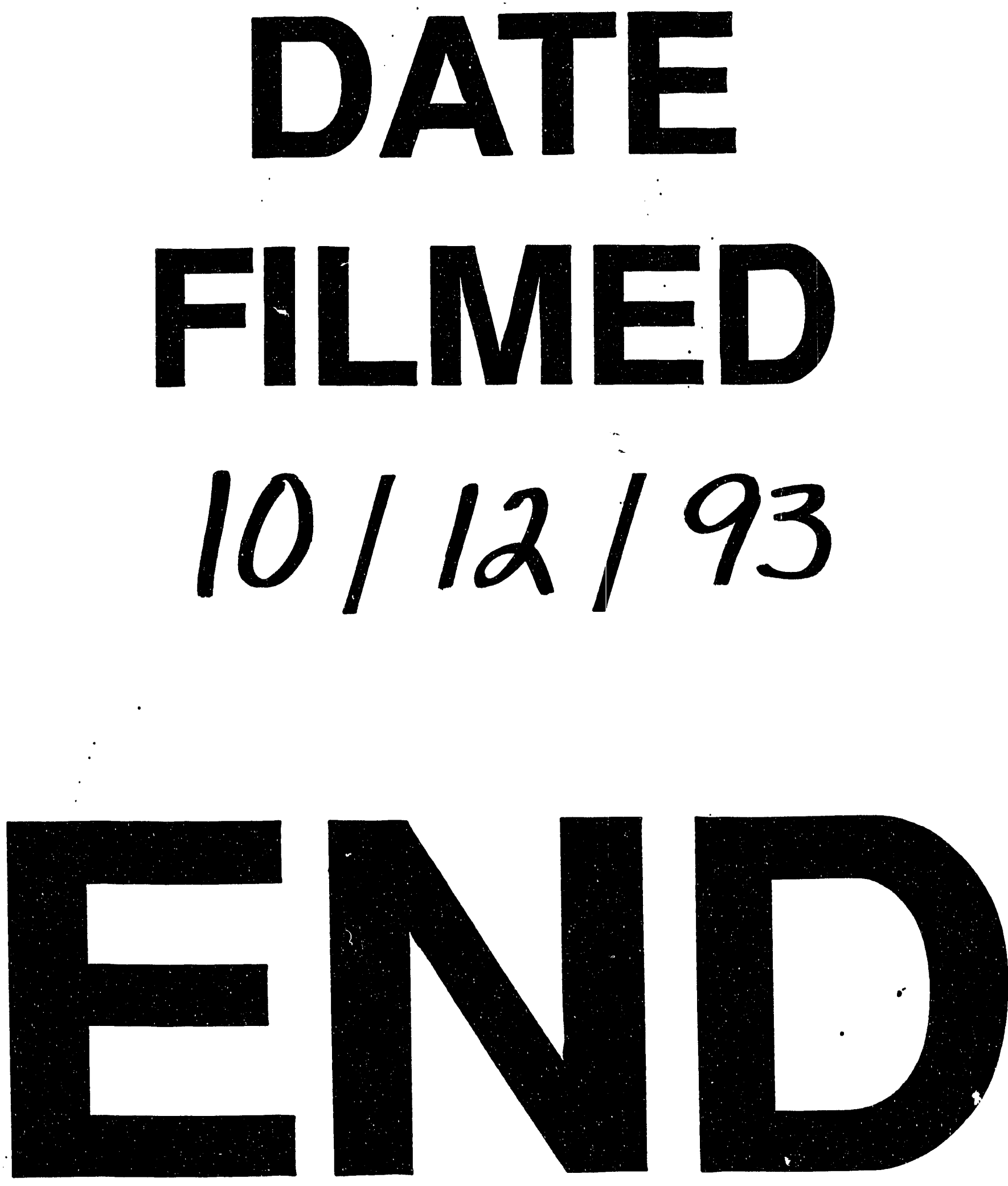
